Leonardo Costa Braga

\title{
Avaliação Experimental de Depósitos em Bicos de um Motor com Injeção Direta de
}

Gasolina

Dissertação apresentada como requisito parcial para obtenção do título de Mestre pelo Programa de PósGraduação em Engenharia Mecânica da PUC-Rio.

Orientador: Prof. Carlos Valois Maciel Braga Co-orientadora: Prof. ${ }^{a}$ Ana Rosa Martins 


\title{
Avaliação Experimental de Depósitos em Bicos de um Motor com Injeção \\ Direta de Gasolina
}

\begin{abstract}
Dissertação apresentada como requisito parcial para obtenção do título de Mestre pelo Programa de PósGraduação em Engenharia Mecânica da PUC-Rio. Aprovada pela Comissão Examinadora abaixo assinada.
\end{abstract}

Prof. Carlos Valois Maciel Braga, Ph.D.

Orientador

Departamento de Engenharia Mecânica - PUC-Rio

Prof. ${ }^{a}$ Ana Rosa Martins, Ph.D.

Co-Orientador

Instituto Tecnológico - PUC-Rio

Prof. Jose Alberto dos Reis Parise, Ph. D.

Departamento de Engenharia Mecânica - PUC-Rio

Guilherme Bastos Machado, D. Sc.

PETROBRAS

Prof. José Eugênio Leal

Coordenador Setorial do Centro Técnico Científico - PUC-Rio

Rio de Janeiro, 11 de Dezembro de 2012 
Todos os direitos reservados. É proibida a reprodução total ou parcial do trabalho sem autorização da universidade, do autor e do orientador.

\section{Leonardo Costa Braga}

É formado em Engenharia Mecânica pela Pontifícia Universidade Católica do Rio de Janeiro (2010). Tem experiência na área de instrumentação, tendo atuado na área de sensores à fibra óptica. Atualmente trabalha na área de energia, em projetos de pesquisa e desenvolvimento no setor de engenharia veicular.

Ficha Catalográfica

Braga, Leonardo Costa

Avaliação Experimental de Depósitos em Bicos de um Motor com Injeção Direta de Gasolina / Leonardo Costa Braga; orientador: Carlos Valois Maciel Braga. - 2012.

114 f.: il. (color.) ; $30 \mathrm{~cm}$

Dissertação de Mestrado - Pontifícia Universidade Católica do Rio de Janeiro, Departamento de Engenharia Mecânica, 2012.

Inclui referências bibliográficas.

1. Introdução; 2. Referências Bibliográficas; 3. Aparato Experimental; 4. Metodologias; 5. Resultados e discussões; 6. Conclusões. I. Braga, Carlos Valois Maciel. II. Pontifícia Universidade Católica do Rio de Janeiro. Departamento de Engenharia Mecânica. III. Título. 


\section{Agradecimentos}

Ao Prof. Carlos Valois Maciel Braga, orientador do projeto, pela amizade, orientação, dedicação e apoio durante o desenvolvimento do projeto.

À Ana Rosa Martins, co-orientadora do projeto, pelo grande apoio técnico e companheirismo ao longo de todo o desenvolvimento deste trabalho.

Ao CNPq e à PUC-Rio, pelos auxílios concedidos, sem os quais este trabalho não poderia ter sido realizado.

Ao Sergio Leal Braga, que além de pai e professor, foi sempre minha grande fonte de inspiração na escolha da minha profissão.

À minha mãe, Christiane L. C. C. Braga, pelo carinho e apoio incondicional a todos os projetos em que estive envolvido ao longo da vida.

À minha irmã, Clarice Braga, pelo companheirismo de sempre.

A todos os funcionários do Instituto Tecnológico pelo apoio e parceria.

Aos meus amigos de trabalho, Júlio, Fernando, Juan, Severino, Nestor, Gilson, Jorge, Bruno, Felipe, Lucas, por todo suporte técnico, paciência e compreensão.

Aos membros da equipe PSA Peugeot-Citroen por não medir esforços para que o projeto acontecesse.

À minha namorada, Ana Alkmim, e sua família por todo o carinho e incentivo.

A todos os amigos e familiares que contribuíram, estimulando e acreditando, para que este trabalho fosse realizado. 


\section{Resumo}

Braga, Leonardo Costa; Braga, Carlos Valois Maciel (Orientador); Martins, Ana Rosa (Co-Advisor). Avaliação Experimental de Depósitos em Bicos de um Motor com Injeção Direta de Gasolina. Rio de Janeiro, 2012. 114p. Dissertação de Mestrado - Departamento de Engenharia Mecânica, Pontifícia Universidade Católica do Rio de Janeiro.

O desenvolvimento de um motor de quatro tempos, de ignição por centelha, com injeção direta de combustível dentro da câmara de combustão foi uma iniciativa importante para o mercado automobilístico mundial. O potencial termodinâmico deste tipo de motor e sua notória melhoria na economia de combustível têm feito com que a tecnologia seja foco de um grande número de projetos de pesquisa, com o objetivo de entender, desenvolver e aperfeiçoar o sistema de injeção direta de combustível. No entanto, para atender aos novos limites de emissões estabelecidas pela especificação EURO 5, foi necessária uma reavaliação do projeto da geometria do injetor, o que ocasionou no desenvolvimento de um novo componente com um maior número de furos e com uma redução do diâmetro dos mesmos (injetor multifuros). Essa alteração no projeto visa garantir uma melhor pulverização, otimização da relação ar/combustível e, consequentemente, um melhor processo de queima na câmara de combustão, atendendo dessa forma os limites de emissões estabelecidos pela diretriz normativa vigente. Os processos de preparação da mistura, injeção, vaporização e controle do escoamento de ar dentro do cilindro têm sido as principais fontes de publicações de periódicos que estudam o sistema de injeção direta. O presente trabalho, por sua vez, tem por finalidade avaliar a formação de depósitos de compostos inorgânicos nos injetores, provenientes da utilização de combustíveis formulados com diferentes teores de sulfato. $\mathrm{O}$ motor utilizado para execução dos testes foi o EP6CDT da PSA Peugeot Citroën. No estudo foram realizados ensaios em bancada de testes e em veículos (estrada e dinamômetro). Outros veículos com a mesma tecnologia, disponíveis no mercado brasileiro, também foram testados. As variáveis avaliadas durante o projeto foram: a composição química de diferentes combustíveis, fator de correção do tempo de injeção (FRA) e a vazão através dos bicos injetores no decorrer dos testes. Os estudos indicaram que a mudança na geometria dos injetores, somada a composição das gasolinas nacionais testadas, originou a formação dos depósitos 
que será discutida ao longo deste trabalho.

\section{Palavras-chave}

Depósitos; Bicos injetores; Motor de injeção direta de combustível; Origem inorgânica; Vazão; Combustível; Dinamômetro de chassis. 


\section{Abstract}

Braga, Leonardo Costa; Braga, Carlos Valois Maciel (Advisor); Martins, Ana Rosa (Co-Advisor). Experimental evaluation of deposits in fuel injectors of a gasoline direct injection engine. Rio de Janeiro, 2012. 114p. MSc. Dissertation - Departamento de Engenharia Mecânica, Pontifícia Universidade Católica do Rio de Janeiro.

The development of a four-stroke engine, spark ignition, with direct injection of fuel into the combustion chamber was an important initiative for the global automotive market. The thermodynamic potential of this type of engine and its significant improvement in fuel economy have meant this technology as focus of a large number of research projects, with the objective to understand, develop and improve the system of direct fuel injection. However, to meet new emission limits set by Euro 5 specification, it was necessary to reevaluate the geometry design of the injector, which resulted in the development of a new component with a larger number of holes and with a diameter reduction (multi-holes injector). This change in the project aims to ensure a better spray, optimizing air / fuel ratio and, consequently, a better process of combustion inside the combustion chamber, satisfying the emission limits established by the applicable norms. The processes for preparing the mixture, injection, atomization and air flow control inside the cylinder have been the main source of periodic publications that study the direct injection system. Therefore, this paper purpose is to evaluate the formation of inorganic deposits in the injectors using fuels formulated with different amounts of sulfate. The engine used for running the tests was the EP6CDT of PSA Peugeot Citroën. For this study one has performed tests on test bench and in vehicles (road and dynamometer). Other vehicles, with the same technology available in Brazil, were also tested. The variables evaluated during the project were: the chemical composition of different fuels, the correction factor from the injection time (FRA) and flow through the injectors during the tests. This study has indicated that the injector geometry modification, coupled with tested compositions of gasoline, resulted in the formation of deposits that will be discussed throughout this work.

\section{Keywords}

Deposits; Fuel injectors; Gasoline direct injection engine; Inorganic deposits; Fuel flow rate; chassis dynamometer. 


\section{Sumário}

1 Introdução 17

1.1. Considerações Gerais 17

1.2. Motivação 20

1.3. Objetivos 21

1.4. Estrutura da dissertação 21

2 Revisão Bibliográfica $\quad 23$

3 Aparato Experimental 28

3.1. Motor EP6 CDT 28

3.2. Veículos utilizados durante os testes 30

3.3. Ensaios de acúmulo de quilometragem 34

3.3.1. Dinamômetro de chassis AVL - "ZÖLLNER 48" 35

3.3.1.1. Simulação da inércia na estrada 36

3.3.2. Autopiloto STHALE SAP 2000

3.3.3. Módulos ETAS ES590.1 e ES581.3 40

3.3.4. Ventilador de resfriamento 41

3.3.5. Sistema de controle e aquisição de dados 43

3.3.5.1. Interface do usuário AVL - ZÖLLNER 43

3.3.5.2. Interface do usuário Autopiloto SAP 2000

3.3.5.3. Interface ETAS - INCA 46

3.4. Bancada de medição de vazão $\quad 47$

3.4.1. Bico injetor 48

3.4.2. Bomba elétrica de combustível (baixa pressão) 50

3.4.3. Bomba mecânica de combustível (alta pressão) 51

3.4.4. Sistema de controle $\quad 51$

3.4.4.1. Módulo EFS High Pressure Regulator (HPR) 52

3.4.4.2. Módulo EFS Ipod Coil Injector Power Driver 53

3.4.4.3. Gerador de funções arbitrárias $\quad 56$

3.5. Análise Química dos Depósitos $\quad 59$ 
3.5.1. Microscópio Eletrônico de Varredura (MEV) com EDX acoplado 59

3.6. Análise química de combustíveis 60

4 Metodologias $\quad 62$

4.1. Ensaios no dinamômetro de chassis 62

4.2. Road Test 63

4.3. Teste de vazão dos injetores 64

4.4. Teste de vazão dos injetores com temperaturas elevadas 65

4.5. Caracterização química dos depósitos 67

4.6. Caracterização química dos combustíveis 68

5 Resultados e discussões $\quad 70$

5.1. Road Test preliminar 70

5.1.1. Caracterização dos depósitos formados em um injetor utilizado no Roads Tests preliminares 72

5.2. Teste de vazão com temperaturas elevadas $\quad 80$

5.3. Dinamômetro de chassis - primeira etapa 81

5.3.1. Dinamômetro de chassis - Peugeot 3008 - combustível C1 83

5.3.2. Dinamômetro de chassis - Peugeot 3008 - combustíveis $\mathrm{C} 1 / \mathrm{C} 288$

5.4. Dinamômetro de chassis - segunda etapa 91

5.4.1. Dinamômetro de chassis - Peugeot 408 - combustível C2 92

5.4.2. Dinamômetro de chassis - Peugeot 408 - combustível C3 95

5.5. Dinamômetro de chassis - terceira etapa 99

5.5.1. Dinamômetro de chassis - Peugeot 207 - combustível C4 99

5.6. Road Test 105

5.6.1. Aditivo $1 \quad 105$

5.6.2. Aditivo $2 \quad 106$

5.6.3. Aditivo $3 \quad 108$

6 Conclusões e Recomendações 110

$\begin{array}{ll}\text { Referências bibliográficas } & 113\end{array}$ 


\section{Lista de figuras}

Figura 3.1: Vista lateral de motor EP6 CDTm 29

Figura 3.2: Curva de torque e potência em função da rotação do motor EP6 30

Figura 3.3: Peugeot 3008 -Veículo utilizado na primeira fase de testes

em dinamômetro 31

Figura 3.4: Peugeot 408 -Veículo utilizado na segunda fase de testes em dinamômetro $\quad 32$

Figura 3.5: Peugeot 207 - utilizado na terceira fase de testes. 33

Figura 3.6: Esquema dos ensaios realizados no dinamômetro de chassis $\quad 34$

Figura 3.7: Dinamômetro de chassis utilizado nos ensaios 35

Figura 3.8: Autopiloto SAP $2000 \quad 38$

Figura 3.9: Interface de comunicação ETAS 590.1 40

Figura 3.10: Interface de comunicação ETAS 581.3 41

Figura 3.11: Vistas lateral e frontal do ventilador de resfriamento. 42

Figura 3.12: Interface gráfica AVL ZÖLLNER 44

Figura 3.13: Interface gráfica do usuário Autopiloto SAP 2000.

Figura 3.14: Parte do ciclo "velocidade $\times$ tempo", elaborado para o veículo no dinamômetro de chassis. $\quad 46$

Figura 3.15: Interface de leitura das variáveis da UCE no INCA. 47

Figura 3.16: Bancada de testes de vazão dos injetores 48

Figura 3.17: Esquema de um perfil de corrente do tipo "peak and hold". 49

Figura 3.18: Imagem da bomba de baixa pressão. $\quad 50$

Figura 3.19: Esquemático da banca de vazão 52

Figura 3.20: Imagem do módulo EFS Ipod Coil. 54

Figura 3.21: Tela de comando da interface de controle do módulo de controle da injeção, EFS Ipod Coil. 55

Figura 3.22: Imagem das ondas quadradas enviadas ao módulo EFS. 57

Figura 3.23: Imagem do gerador de funções arbitrárias utilizado durante os ensaios. $\quad 58$

Figura 3.24: Microscópio eletrônico de varredura com EDX acoplado. $\quad 59$

Figura 4.1: (a) Foto do ensaio no dinamômetro de chassis; (b) detalhe do 
robô piloto durante um dos testes realizados.

Figura 4.2: Imagem esquemática do teste de vazão com temperaturas elevadas. 66

Figura 4.3: Detalhe da instalação do termopar na peça de alumínio.

Figura 5.1: Acompanhamento FRA - Primeiro Road Test preliminar, gasolina $C 0$

Figura 5.2: Acompanhamento FRA - Segundo Road Test preliminar, gasolina $C 0$

Figura 5.3: Visão frontal de um injetor: (a) injetor novo (antes dos testes)

(b) injetor retirado do veículo após um teste.

Figura 5.4: Visão frontal dos injetores mostrados na Figura 5.3 utilizando um microscópio estereoscópico.

Figura 5.5: Imagem da superfície exterior do injetor, feita com o microscópio eletrônico de varredura.

Figura 5.6: Detalhe da região em destaque na Figura 5.5 e dos pontos

1,2,3 e 4 escolhidos para análise (imagem realizada com o MEV).

Figura 5.7: Análise dos pontos 1,2,3 e 4, mostrados na Figura 5.6, realizada por EDS, no microscópio eletrônico de varredura.

Figura 5.8: (a) Detalhe da região identificada pelo ponto 3 da Figura 5.5, feita com o MEV. (b) Espectro característico da região indicada pelo ponto 1 da Figura 5.8 (a).

Figura 5.9: (a) Detalhe do injetor ilustrado na Figura 5.5. (b) Espectro da região especificada pelo ponto 1. (c) Espectro da região especificada pelo ponto 3.

Figura 5.10: (a) Vista frontal do injetor depositado. Secção longitudinal. A seta indica a região analisada (Figuras 5.11 e 5.12). (b) Detalhe da secção longitudinal do injetor.

Figura 5.11: (a) Região identificada pela seta na Figura 5.10. (b) Espectro da região indicada pelo ponto 1 .

Figura 5.12: (a) Detalhe da região identificada por 1 na Figura 5.11. Imagem feita com o MEV. (b) Espectro da análise da região indicada pelo ponto 1.79 Figura 5.13: Massa injetada por distância simulada na bancada de vazão. $\quad 81$ Figura 5.14: Vista frontal do bico (imagem utilizando lupa estereoscópica). 85 
Figura 5.15: (a) Região dos furos do bico injetor; (b) Imagem detalhada de um furo e os pontos analisados utilizando o MEV.

Figura 5.16: Espectros referentes aos pontos 1 e 6 do furo analisado

(Figura 5.15).

Figura 5.17: (a) Detalhe de outro furo ilustrado nas Figuras 5.14 e 5.15, imagem por microscopia eletrônica de varredura; (b) Espectro referente à análise realizada na região indicada por 1 .

Figura 5.18: (a) Seção transversal de um bico injetor; (b) Espectro referente à análise da região indicada.

Figura 5.19: Veículo sendo testado com linha de combustível toda metálica.

Figura 5.20: Acompanhamento contínuo da variável de adaptação do tempo de injeção ao longo do ensaio realizado com a gasolina $C 1$.

Figura 5.21: Acompanhamento contínuo do FRA ao longo do ensaio realizado com a gasolina $C 2$.

Figura 5.22: Comparação entre os bicos injetores que saíram do teste de dinamômetro com a gasolina C2 e um bico injetor novo, de referência.

Figura 5.23: Acompanhamento do FRA para o ensaio em dinamômetro utilizando gasolina $\mathrm{C} 3$.

Figura 5.24: Vazão comparativa entre os bicos injetores 1,2,3 e 4, após o ensaio em dinamômetro de chassis com um bico injetor novo.

Figura 5.25: Acompanhamento da variável de correção do tempo de injeção ao logo do ensaio utilizando a gasolina $\mathrm{C} 4$, no dinamômetro de chassis.

Figura 5.26: Resultado do teste de vazão feito no bico injetor referente ao cilindro 1, antes e depois do ensaio.

Figura 5.27: Resultado do teste de vazão feito no bico injetor referente ao cilindro 2, antes e depois do ensaio.

Figura 5.28: Resultado do teste de vazão feito no bico injetor referente ao cilindro 3 , antes e depois do ensaio.

Figura 5.29: Resultado do teste de vazão feito no bico injetor referente ao cilindro 4, antes e depois do ensaio.

Figura 5.30: Acompanhamento da variável FRA, para o grupo de veículos, ao longo dos ensaios feitos com o primeiro aditivo.

Figura 5.31: Acompanhamento da variável FRA ao longo dos ensaios feitos 
com o segundo aditivo.

Figura 5.32: Acompanhamento da variável FRA ao longo dos ensaios

feitos com o terceiro aditivo.

109

Figura 6.1: Resumo gráfico dos principais resultados obtidos nos testes

de dinamômetro de chassis e ensaios de vazão nos bicos injetores.

111 


\section{Introdução}

\subsection{Considerações Gerais}

O delicado balanço entre demanda e fornecimento de energia, quando colocado lado a lado com o crescimento das preocupações ambientais relacionadas à queima de combustível, tem resultado no aumento da complexidade dos projetos de veículos, a fim de que os mesmos respeitem a meta rigorosa dos novos protocolos de emissões. Esta preocupação tem levado engenheiros automotivos ao redor do mundo a desenvolver novas tecnologias atreladas a motores de combustão interna (MCI), que levem, entre outros objetivos, a um melhor consumo específico de combustível.

Nas últimas décadas, diversas tentativas de otimização dos motores a combustão interna foram realizadas. Um dos componentes que sofreu grandes alterações foi o sistema de injeção de combustível. Os motores de ignição por centelha, por exemplo, utilizaram por um longo o carburador que, posteriormente, foi substituído pelo sistema de injeção eletrônica de combustível. Na época dos carburadores, os motores não dispunham de sensores de temperatura e pressão ou de qualquer instrumentação mais sofisticada no motor. Com isso, não havia otimização na injeção de combustível, além destes motores não conseguirem atender os padrões de emissões que vinham ficando cada vez mais rigorosos. Por sua vez, os motores com injeção eletrônica permitem, através da leitura dos sensores no motor, uma correção na injeção. Desta forma, pode-se garantir que o motor trabalhe sempre buscando se manter próximo da relação ideal de ar/combustível. Como exemplo da importância desta regulagem, pode-se citar a variação da composição gasolina brasileira, considerando que o teor de etanol em sua formulação é constantemente alterado em função do mercado de cana de açúcar. A injeção eletrônica permite que se otimize a quantidade de combustível injetado, devido à diferença no poder calorífico e relação ar-combustível 
estequiométrica da gasolina e do etanol. O sistema eletrônico ainda possibilita partidas mais rápidas, através do melhor controle do enriquecimento da mistura quando o motor está frio, fazendo-o voltar ao normal após seu aquecimento. O primeiro sistema de injeção eletrônica amplamente implementado foi o de injeção monoponto no pórtico de admissão, onde um bico de injetor era posicionado no início do coletor de admissão. Neste modo de injeção, a mistura ar/combustível era preparada dentro do coletor e em seguida admitida na câmara de combustão para iniciar o processo de queima. Com o passar do tempo, este sistema foi otimizado, passando a ter o mesmo número de injetores e cilindros, e foi denominado de injeção multiponto no pórtico de admissão (MPFI). Com esta alteração de projeto, os bicos injetores foram posicionados mais próximos as válvulas de admissão, garantindo uma injeção mais precisa, uniforme e controlada. Porém, ainda na busca por menores consumos de combustível e uma maior potência, engenheiros automotivos procuraram desenvolver um motor que tivesse a capacidade de combinar as melhores características possíveis encontradas nos motores de ignição por centelha (SI) com as apresentadas pelos motores de ignição por compressão (CI). O consumo específico de combustível dos motores de ignição por compressão e injeção direta é inferior ao dos motores com ignição por centelha e injeção no pórtico de admissão. Deve ser ressaltado que motores a ignição por compressão, além de apresentarem um nível maior de ruídos e operarem em uma faixa mais limitada de rotação, costumam apresentar valores maiores de emissões de $N O_{x}$ e particulados, quando comparados aos motores de ignição por centelha. $\mathrm{O}$ foco da procura por novas tecnologias estava em combinar a potência específica dos motores SI com a maior eficiência dos motores CI em cargas parciais.

Entre os projetos desenvolvidos, deve-se destacar os motores com injeção direta e ignição por centelha, que vêm ganhando cada vez mais espaço no mercado automobilístico mundial. A tendência é que a penetração desta nova tecnologia no mercado aconteça de forma rápida, uma vez que a mesma promete mais potência e menor consumo de combustível. Além disso, a tecnologia apresenta menores níveis de emissões de poluentes e uma menor atuação da borboleta quando comparada aos motores de ignição por centelha e injeção no pórtico de admissão (PFI). 
Porém, a manufatura deste tipo de motor ainda não está totalmente viabilizada no mercado devido às dificuldades atreladas ao tratamento dos produtos de queima, maior nível de emissões de particulados, além de problemas de custo e complexidade de projeto.

Questões relacionadas à formação de depósitos em motores de injeção direta de gasolina e em seus bicos injetores, são de grande interesse, tanto para os fabricantes de motor, quanto para os produtores de gasolina e etanol.

Sabe-se que em território brasileiro, por força de lei, 18 a $25 \%$ da composição da gasolina é etanol (gasolina C). Além disso, a gasolina brasileira contém, uma maior quantidade de enxofre quando comparada aos padrões de gasolina europeu e americano, mostrados na Tabela 1.1, a seguir.

Tabela 1.1: Características das gasolinas Brasileira, Americana e Europeia.

\begin{tabular}{|l|c|c|c|}
\hline \multicolumn{1}{|c|}{ Características } & $\begin{array}{c}\text { Gasolina } \\
\text { Brasileira }\end{array}$ & $\begin{array}{c}\text { Gasolina } \\
\text { Americana }\end{array}$ & Gasolina Européia \\
\hline Enxofre (ppm) & 700 & 69 & 10 \\
\hline Tolueno (\%volume) & 2 & - & - \\
\hline Benzeno (\%volume) & 0,98 & 0,66 & 46 \\
\hline Saturados (\%volume) & 37,8 & 66 & 18 \\
\hline Olefinas (\%volume) & 32,7 & 11,9 & 35 \\
\hline $\begin{array}{l}\text { Aromáticos } \\
(\% \text { volume) }\end{array}$ & 29,5 & 20,9 & \\
\hline
\end{tabular}

Estas diferenças em composição, podem afetar tanto o processo de combustão, quanto os níveis de emissões e o processo de formação dos depósitos na câmara de combustão e nos bicos injetores.

Conhecendo os processos de fabricação e os limites aplicados aos combustíveis no Brasil, foram formuladas, neste trabalho, gasolinas com diferentes percentuais de enxofre de acordo com as especificações da norma técnica da ANP (Agência Nacional de Petroleo, Gás Natural e Biocombustíveis), $\mathrm{N}^{\circ}$ 7, de 2011. Estas gasolinas foram testadas em veículos que utilizavam um motor EP6 CDTM, com sistema de injeção direta de gasolina (GDI), a fim de se 
verificar a influência da composição do combustível na formação dos depósitos nos bicos injetores.

Diferentes veículos, empregando o motor acima mencionado, foram testados segundo ciclos normalizados de acúmulo de quilometragem para veículos leves, em dinamômetro de chassis, e através de testes realizados no trânsito urbano/estradas, conhecidos como road tests.

Pôde-se notar, através de ensaios preliminares, que a formação de depósitos nos injetores com tais formulações de combustíveis, ocorria em quilometragens relativamente baixas. Ensaios indicam, ainda, que a formação de depósitos na superfície e no interior dos bicos injetores, afeta a vazão de combustível, assim como a geometria do spray de gasolina. Nestes motores, para que a vazão de combustível permaneça a mesma, a medida que os depósitos vão se formando, um fator de correção é aplicado eletronicamente, através da unidade de controle eletrônico (UCE), sobre o tempo de injeção. Este fator tem como objetivo diminuir os impactos relacionados à formação de depósitos no funcionamento otimizado do motor e é chamado ao longo do trabalho de FRA. Sob condições normais de operação, sem deposição nos injetores, o valor de FRA se mantém próximo a um, seu valor nominal. A medida que o injetor começa a sofrer obstrução, o valor do FRA aumenta, aumentando o tempo de injeção em até trinta por cento.

A fim de avaliar esse fenômeno, ao longo do presente trabalho, investigações foram realizadas com o intuito de se compreender a formação dos depósitos e sua consequente influência na vazão de combustível, relacionado a diferentes composições de gasolinas.

\subsection{Motivação}

Sabe-se que a composição química dos combustíveis desenvolve um papel de grande importância na formação de depósitos no interior da câmara de combustão, assim como nos bicos injetores. Porém, muito ainda há de ser investigado em relação à formação e composição química destes depósitos. Motores de diferentes tecnologias tendem a apresentam diferentes mecanismos de 
deposição. É o caso, por exemplo, de motores com injeção no pórtico de admissão ou de injeção direta de combustível na câmara de combustão. Para o primeiro caso, muitos estudos já foram realizados, existindo inclusive no Brasil uma norma técnica para ciclos de formação destes depósitos. Quando o assunto é injeção direta de combustível, um menor número de estudos foi realizado devido ao fato de ser uma tecnologia mais recente no mercado automobilístico mundial. Quando esta realidade é trazida para o Brasil, onde esta tecnologia é ainda incipiente, as publicações referentes a depósitos são praticamente inexistentes. Deve ser considerado ainda que no Brasil, 18 a 25\% da composição da gasolina comercial é etanol anidro, portanto, bastante diferente dos combustíveis onde estes motores foram desenvolvidos. Devido a este fato, surge a necessidade de se investigar as consequências da adição de etanol a gasolina, entre outros componentes, tais como enxofre, cuja regulação brasileira difere substancialmente dos demais países que fazem o uso desta tecnologia.

Todos os fatores acima citados justificam a necessidade de uma pesquisa para avaliar a influencia da composição do combustível na formação de depósitos em motores de injeção direta.

\subsection{Objetivos}

Nesta dissertação, os esforços foram concentrados em estudar a formação de depósitos em bicos injetores de um motor com injeção direta de gasolina (GDI). Assim, os objetivos deste trabalho foram:

1. Testar em, dinamômetro de chassis, veículos que utilizem motores de tecnologia GDI e analisar seu comportamento, quanto ao surgimento de depósitos, para diferentes formulações de gasolina nacional.

2. Avaliar a composição química dos depósitos formados durante os ensaios realizados, e verificar sua influência na vazão de combustível através dos injetores.

\subsection{Estrutura da dissertação}


A dissertação foi divida em seis capítulos. O presente capítulo (número 1) apresenta uma consideração geral sobre o tema proposto, assim como a motivação e os objetivos que alavancaram as pesquisas para dissertação em questão.

No capítulo dois, a seguir, apresenta-se a revisão bibliográfica sobre o tema proposto.

O capítulo três, por sua vez, apresenta o aparato experimental utilizado para a realização dos ensaios. As metodologias adotadas para estes ensaios foram descritas detalhadamente no quarto capítulo.

Os resultados obtidos experimentalmente no dinamômetro de chassis, bancada de testes de vazão, road test, e as análises químicas dos combustíveis utilizados, assim como dos depósitos formados estão apresentados e foram analisados no capítulo cinco.

Com base nos resultados obtidos ao longo os ensaios realizados, o sexto capítulo apresenta as conclusões e sugere os trabalhos que devem ser realizados para dar continuidade na compreensão do fenômeno estudado. 


\section{2 \\ Revisão Bibliográfica}

A formação de depósitos é uma preocupação extremamente relevante nos projetos de injetores dedicados a aplicações de injeção direta de gasolina (GDI). Em função disso, devem ser concedidos tempo e recursos suficientes para pesquisas no programa do desenvolvimento de qualquer motor GDI.

De acordo com F. Zhao et al. [1], as condições de operação dos injetores de gasolina dentro do cilindro são consideravelmente mais severas que em sistemas de injeção no pórtico de admissão (PFI). Sendo assim, a formação de depósitos na ponta dos injetores acontece de forma muito mais rápida do que as acompanhadas em motores PFI. Devido ao fato dos injetores de um motor diesel trabalhem em condições ainda mais severas, os depósitos tendem a se formar mais rapidamente em motores do tipo GDI.

Um dos fatores importantes na formação dos depósitos é o combustível utilizado. Outro ponto de grande influência é a faixa de pressão em que estes bicos injetores operam. No caso de motores de ignição por compressão, esta faixa de pressão pode variar em torno de 500 a 1800 bar, aproximadamente. Já os motores de ignição por centelha com injeção direta de combustível tem sua pressão de injeção variando na faixa de 5 bar, quando em regime de marcha lenta, até aproximadamente 140 bar, dependendo do seu regime de operação. Esta pressão não é suficiente para afetar mecanicamente a deposição contínua de material rico em carbono na ponta do injetor. Desta maneira, o projeto de bicos injetores de motores do tipo GDI é, de certa forma, particularmente crítico na formação de depósitos. Desde sua primeira aparição no mercado automobilístico mundial, os projetos de motores GDI vêm sendo alterados, buscando atender aos novos protocolos de emissões. Para isso, visando uma melhor pulverização, menores tamanhos de gotas e uma melhor relação ar/combustível vaporizado, o número de furos no bico injetor vem aumentando. Para que a vazão de combustível se mantenha inalterada, com o aumento de furos no injetor, os diâmetros destas 
cavidades tendem a diminuir, favorecendo ainda mais a formação de depósitos no interior destes injetores.

A consequência da formação de depósitos nos furos do bico injetor pode se manifestar em duas áreas distintas. Sendo a primeira delas a degradação da qualidade do spray de combustível, e a segunda a redução da capacidade estática do injetor, ou seja, uma menor massa de combustível sendo injetada na câmara para um mesmo pulso de injeção.

Segundo F. Zhao [1], na maioria dos motores GDI, a geometria do spray de combustível, principalmente sua simetria, é geralmente perturbada antes da redução na vazão de gasolina chegar a $8 \%$ quando comparada a condição de bico limpo. Uma vez que os motores GDI são normalmente mais sensíveis a variações nos parâmetros do spray que os motores PFI, estes motores exibem grande sensibilidade a pequenos depósitos.

As temperaturas e pressões encontradas na cabeça do injetor podem ser apropriadas para a reações de polimerização da gasolina. Isto leva a formação de um resíduo ceroso nas passagens de combustível pelo injetor, o que pode alterar a calibração de fluxo. Tendo o spray ou as características de escoamento do injetor alteradas, o processo de estratificação, que foi cuidadosamente desenvolvido, será afetado. É esperado que qualquer desvio da condição de operação otimizada tenha um impacto negativo sobre o nível das emissões e a dirigibilidade [2].

É importante enfatizar que a redução na vazão de combustível devido aos depósitos não ocorre de maneira uniforme nos quatro cilindros [1]. Consequentemente, a relação ar/combustível é diferente cilindro a cilindro. $\mathrm{Na}$ maioria dos sistemas de controle, os quatro cilindros do motor recebem o mesmo tamanho de pulso. Assim, os injetores mais depositados injetarão menos.

Ainda segundo F. Zhao et al. [1], dados gerados a partir de um phaseDoppler para jatos distorcidos mostra que a distribuição dos tamanhos de gota (a curva de distribuição de tamanho de gotas) é muito pouco afetada, enquanto a distribuição da velocidade das gotas é alterada significativamente, devido à formação de camadas depositadas.

De acordo com os estudos revisados, um injetor GDI depositado pode chegar a $8 \%$ de redução em sua vazão nominal. É importante salientar que estes estudos foram realizados, em sua totalidade, na Europa, Estados Unidos e Japão, utilizando motores GDI com injetores monofuro. 
Os depósitos observados na superfície inferior crítica do injetor geralmente se enquadra em duas categorias. Uma delas é uma camada bem fina de um revestimento quebradiço que contém compostos de enxofre, enquanto a segunda é rica em carbono. A segunda se forma mais rapidamente, e é normalmente retirada com solventes e aditivos.

Ainda de acordo com a referência [1], os depósitos podem se formar tanto no interior quanto no exterior dos furos do bico injetor. Depósitos internos causam redução na vazão dos injetores, enquanto os depósitos externos geralmente resultam somente na degradação da geometria do jato de combustível.

A geometria dos injetores também é um fator que necessita atenção no estudo da formação de depósitos. Esta desenvolve um papel importante no retardo da formação de camadas depositadas.

Alguns testes para avaliação de depósitos em bicos injetores de motores PFI foram discutidos por Caracciolo e Stebar [3] e por Harrington et al. [4]. Notou-se que os testes realizados em motores PFI não poderiam ser utilizados de maneira efetiva para motores GDI. É conhecido que o tempo em que o motor permanece quente após ser desligado e o histórico de temperatura na ponta do injetor são de importância crítica para a formação de depósitos em motores PFI. Sabe-se também que essas taxas de deposição são relativamente baixas para operações contínuas. Porém, para aplicações GDI, os estudos têm indicado que a formação de depósitos é favorecida, sim, pela operação contínua, o que a difere da formação de depósitos da ocorrente em sistemas PFI.

A localização centralizada do injetor, na câmara de combustão, ocasiona maiores cargas térmicas do que as observadas quando este está localizado abaixo do pórtico de admissão. Esta diferença de posicionamento pode submeter a extremidade do injetor a temperaturas cerca de 10 a $15^{\circ} \mathrm{C}$ superiores. Segundo Jackson et al. [2], a temperatura a qual a extremidade de um injetor do tipo GDI é submetida, pode variar de 150 a $200^{\circ} \mathrm{C}$. Análises bidimensionais de elementos finitos e cálculos analíticos provaram que o maior fluxo de calor, proveniente da chama no interior do cilindro, ocorre no centro da câmara de combustão. Sendo assim, para minimizar a temperatura na ponta de um injetor central, é necessário que o mesmo se encontre o mais próximo das válvulas de admissão. Segundo engenheiros da Toyota, para evitar que a formação de depósitos ocorresse de 
maneira precoce, a temperatura da ponta do bico deveria ser mantida abaixo de $150^{\circ} \mathrm{C}$, além da utilização de um material orgânico especial na ponta do injetor.

Kinoshita et al. [5] investigou a formação de depósitos em um motor GDI. Os depósitos foram classificados de duas formas: fuligem depositada sobre a superfície do bocal e da agulha, e combustível polimerizado por decomposição térmica de modo a formar um tipo de goma depositada no interior do bocal. Segundo Kinoshita, foi observado que os depósitos foram inicialmente formados na saída do bocal do injetor e posteriormente progrediram para a superfície interna da cavidade. A deposição no interior do injetor ocorreu na posição em que o combustível residia após o término de cada injeção. Tanto a temperatura da cavidade, quanto as características de destilação do combustível foram consideradas significativamente dominantes na formação de depósitos, pelo autor. Observou-se que o injetor, quando submetido a temperaturas elevadas, pode sofrer uma decomposição térmica do combustível em seu interior, onde depósitos precursores são formados. Quando a ponta do injetor está submetida a temperaturas inferiores a $90 \%$ da temperatura de saturação do combustível (T90), a maioria do combustível permanecerá líquido, embora parte possa evaporar antes do próximo evento de injeção. A presença contínua de combustível líquido na superfície do injetor assegura que os precursores dos depósitos são facilmente levados para fora do injetor pelo pulso de injeção seguinte. No entanto, quando a temperatura do combustível testado excede T90, a maioria deste combustível vaporiza ao término da injeção. Consequentemente, os precursores de depósitos se distribuem, e podem se fixar nas cavidades do injetor. Desta maneira, torna-se mais difícil que a próxima injeção retire estes resíduos e, eventualmente, depósitos podem se formar no interior do injetor. Portanto, segundo Kinoshita et al.[5], a teoria sugere que se retenha parte do combustível em fase liquida no interior das cavidades do injetor, entre pulsos de injeção, a fim de retardar a formação de depósitos.

Um estudo do processo de formação de carbono no interior de um tubo foi conduzido por Mao [6], a fim de entender o fenômeno de deposição de injetores de gás de uma turbina. Algumas das conclusões apontadas por Mao podem ser aplicadas, na teoria, aos injetores utilizados em sistemas do tipo GDI. Verificou-se que a temperatura das paredes pode ser o parâmetro mais importante na determinação da taxa de depósitos de carbono, seguido da vazão de combustível e, 
por fim, a temperatura de admissão do combustível. Foi observado que a variação na taxa de formação de depósitos depende se o aparato experimental fornece um fluxo de calor constante ou uma temperatura constante na parede do tubo testado. Mao [6] constatou que a taxa de deposição permanece aproximadamente constante para temperaturas de parede abaixo de um certo valor limite. Com isso, à medida que a temperatura da parede ultrapassa este valor, a taxa de depósitos aumenta de maneira vertiginosa com o aumento da temperatura.

Os estudos conduzidos por Kinoshita [5] e Mao [6], constatando que a taxa de depósitos exibe um máximo como função da velocidade da vazão de combustível. A temperatura de entrada do combustível se mostrou menos influente do que a temperatura da parede. Porém exerce um papel fundamental na formação de depósitos quando as temperaturas da parede se tornam altas.

Resultados experimentais indicaram que, inicialmente, a taxa de formação depósitos diminui com o aumento da temperatura de combustível. Porém depois de um valor mínimo, a taxa de deposição começa a crescer com o aumento da temperatura da gasolina.

A concentração de enxofre, encontrada nos resultados dos estudos apresentados ao longo da revisão bibliográfica, foi relativamente baixa para o caso de depósitos. Mais uma vez, é importante ressaltar que os trabalhos encontrados foram realizados, em sua totalidade, na Europa, Estados Unidos e Japão, onde a formulação de gasolina difere da brasileira. Outro fator importante é o número de furos contidos nos injetores testados. As conclusões obtidas por Kinoshita [5] tiveram como base testes feitos com um injetor mono-furo, porém, acredita-se que os resultados podem ser correlacionados com injetores do tipo multi-furo, utilizados no presente trabalho. 


\section{3 \\ Aparato Experimental}

Todos os experimentos foram realizados no Laboratório de Engenharia Veicular (LEV) da PUC-Rio, com exceção do road test. Neste capítulo serão apresentados detalhadamente os equipamentos utilizados em cada um dos testes realizados neste trabalho.

\subsection{Motor EP6 CDT}

Todos os testes conduzidos ao longo da dissertação utilizaram o motor de ignição por centelha e injeção direta de gasolina EP6, de fabricação Peugeot. Este motor trabalha em regime quatro tempos e tem os quatro cilindros em linha. Sua potência chega a $110 \mathrm{~kW}$ a $5800 \mathrm{rpm}$ e seu torque máximo é de $240 \mathrm{Nm}$ na rotação de $1400 \mathrm{rpm}$. Tal motor é equipado com um turbo-compressor e já é utilizado em alguns veículos leves da PSA Peugeot-Citroën. A Figura 3.1 ilustra o motor testado e a Tabela 3.1 apresenta suas principais características técnicas. 


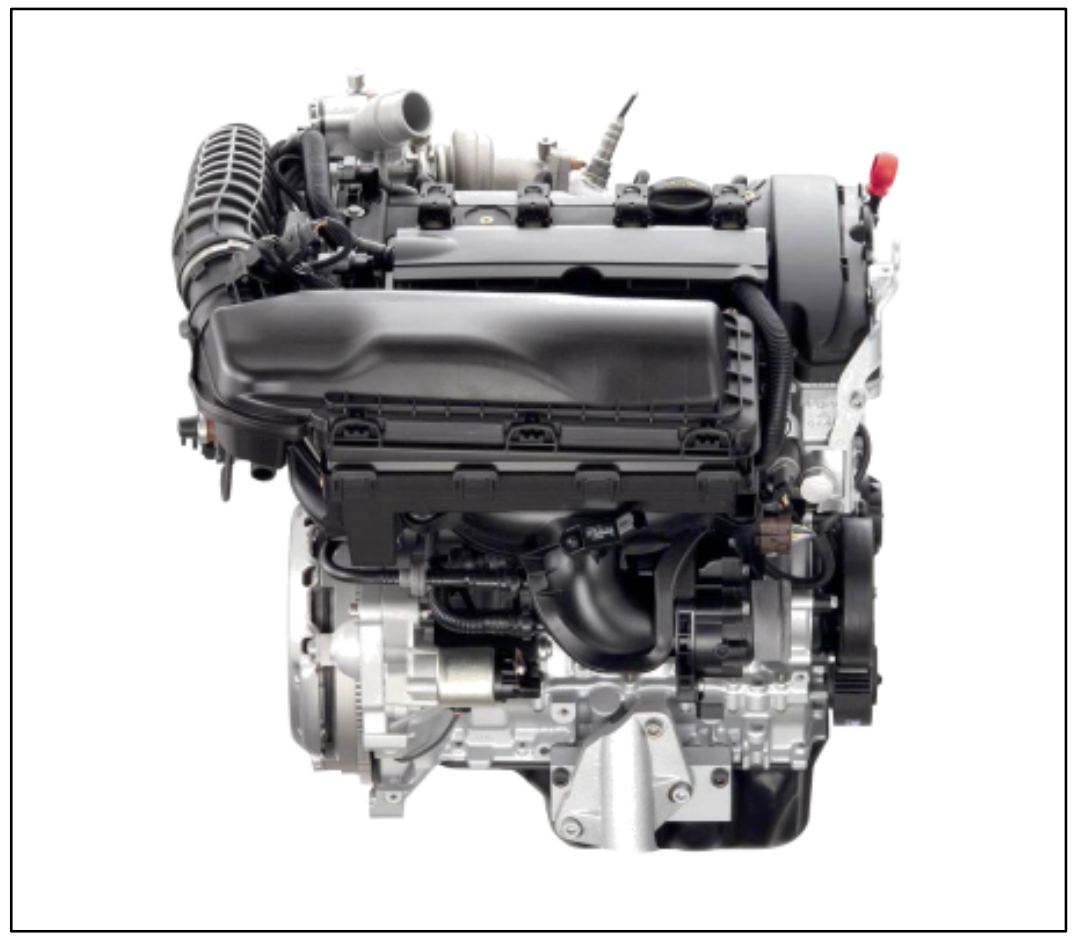

Figura 3.1: Vista lateral de motor EP6 CDTm

Tabela 3.1: Principais características do motor Peugeot EP6.

\begin{tabular}{|l|l|}
\hline Configuração do motor & Cilindros em linha \\
\hline Número de cilindros & 4 \\
\hline Admissão & Turbo-comprimido \\
\hline Válvulas & $\begin{array}{l}\text { DOHC 4 válvulas por cilindro, } \\
\text { comando de válvulas variável }\end{array}$ \\
\hline Tipo de injeção & Eletrônica \\
\hline Tipo de combustível & Gasolina nacional \\
\hline Fornecimento de combustível & $\begin{array}{l}\text { Injeção eletrônica direta, } \\
\text { Turbo, Intercooler }\end{array}$ \\
\hline Modelo do Motor & EP6 CDT turbo \\
\hline Capacidade & 1598 cc \\
\hline Taxa de compressão & $11,0: 1$ \\
\hline Diâmetro curso & 77,0 x 85,8 mm \\
\hline Boost & 0,65 / 0,50 bar \\
\hline Potência & 150 hp a 5800 rpm \\
\hline
\end{tabular}




\begin{tabular}{|l|l|}
\hline Torque & $240 \mathrm{Nm}$ a $1400 \mathrm{rpm}$ \\
\hline
\end{tabular}

A seguir está apresenta a curva de torque e potência do motor utilizado nos veículos testados no dinamômetro de chassis.

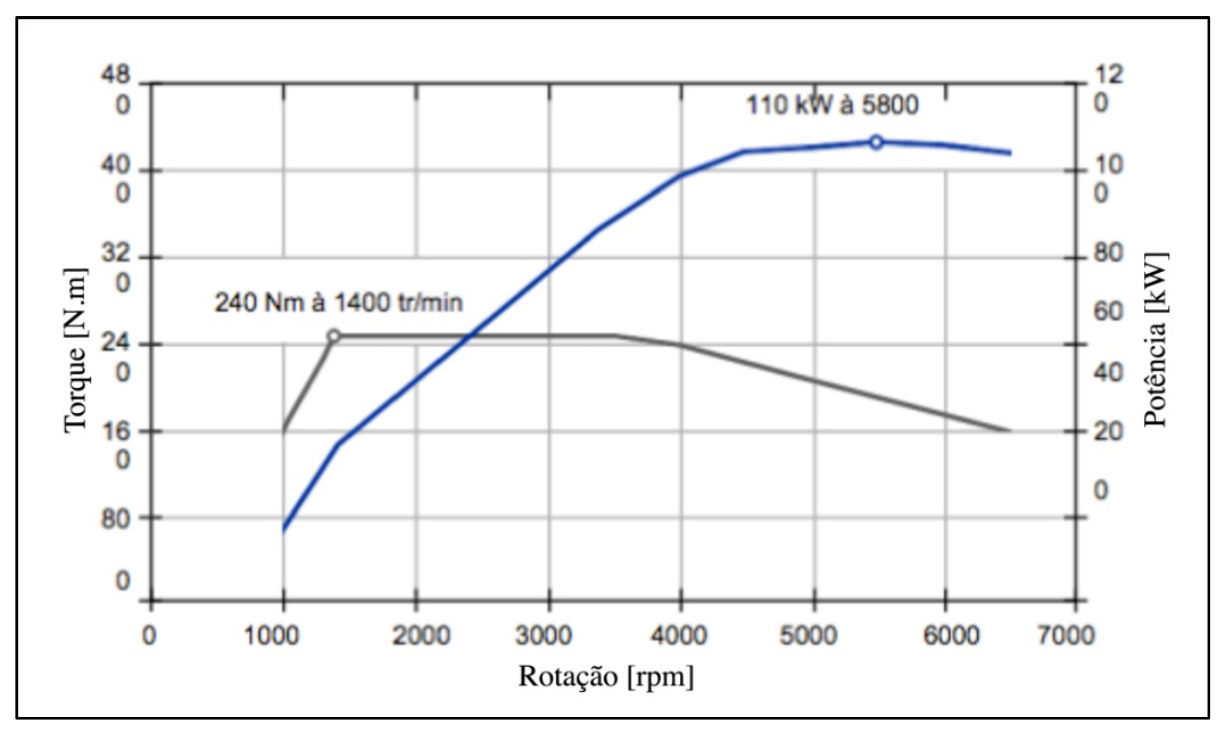

Figura 3.2: Curva de torque e potência em função da rotação do motor EP6

\subsection{Veículos utilizados durante os testes}

Durante os ensaios realizados no dinamômetro de chassis, três veículos foram usados. A primeira série de testes foi realizada utilizando um Peugeot 3008. Em seguida, os testes tiveram continuidade com um Peugeot 408. Por fim, para realizar os últimos testes, foi utilizado um Peugeot $207 \mathrm{hp}$.

A seguir serão apresentados os veículos utilizados, assim como suas principais características técnicas. 


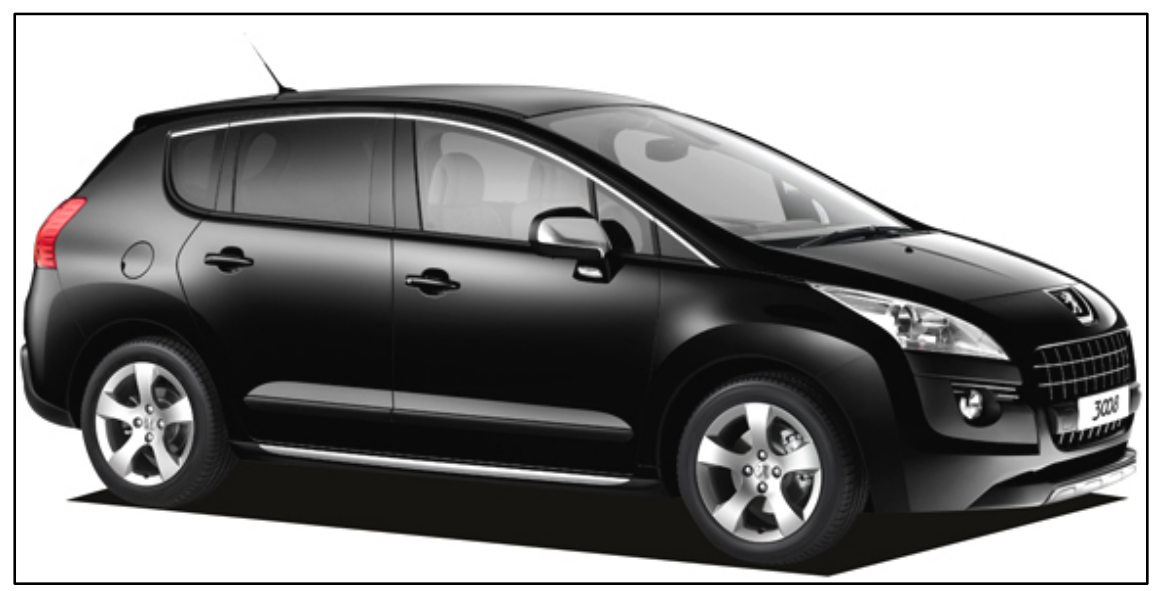

Figura 3.3: Peugeot 3008 -Veículo utilizado na primeira fase de testes em dinamômetro

Tabela 3.2: Principais características técnicas do Peugeot 3008.

\begin{tabular}{|c|c|c|c|}
\hline \multicolumn{2}{|l|}{ MOTOR } & \multicolumn{2}{|c|}{ TRANSMISSÃO E VELOCIDADE } \\
\hline Código & $16 \mathrm{~V} \mathrm{THP}$ & Transmissão & Mecânica \\
\hline Ciclo & Otto & Marchas & 6 \\
\hline Combustível & Gasolina & Velocidade Máxima & $201 \mathrm{~km} / \mathrm{h}$ \\
\hline Cilindrada Total $(\mathrm{cm} 3)$ & 1598 & $\begin{array}{l}\text { Aceleração de 0-100 } \\
\mathrm{km} / \mathrm{h}(\mathrm{s})\end{array}$ & 9,8 \\
\hline Diâmetro x Curso (mm) & $77 \times 88,5$ & \multicolumn{2}{|c|}{ CONSUMO DE COMBUSTÍVEL } \\
\hline $\begin{array}{l}\text { Potencia Máxima, CEE } \\
(\mathrm{kW})\end{array}$ & 115 & Urbano (1/100 km) & 10,8 \\
\hline $\begin{array}{l}\text { Regime de Potencia } \\
\text { Máximo (rpm) }\end{array}$ & 6000 & $\begin{array}{l}\text { Extra urbano }(1 / 100 \\
\mathrm{km})\end{array}$ & 5,8 \\
\hline $\begin{array}{l}\text { Torque Máximo, CEE } \\
\text { (N.m) }\end{array}$ & 240 & Combinado (1/100 km) & 7,6 \\
\hline $\begin{array}{l}\text { Regime de Torque Máximo } \\
\text { (rpm) }\end{array}$ & 1400 & $\begin{array}{l}\text { Emissões de CO2 } \\
(\mathrm{g} / \mathrm{km})\end{array}$ & 179 \\
\hline Combustível & Sem chumbo & $\begin{array}{l}\text { Capacidade do tanque } \\
\text { (litros) }\end{array}$ & 60 \\
\hline Catalisador & Sim & \multicolumn{2}{|c|}{ AERODINÂMICA } \\
\hline \multicolumn{2}{|l|}{ MASSA } & Área $\left(\mathrm{m}^{2}\right)$ & 2,686 \\
\hline Peso bruto $(\mathrm{kg})$ & 1540 & $\begin{array}{l}\text { Coeficiente de arrasto } \\
(\mathrm{Cx})\end{array}$ & 0,296 \\
\hline Peso máximo de carga (kg) & 1680 & Volume total ( m3) & 0,512 \\
\hline Reboque (kg) & 3220 & Pneus & 225/45 R17 \\
\hline Massa máxima (kg) & 1220 & - & - \\
\hline
\end{tabular}




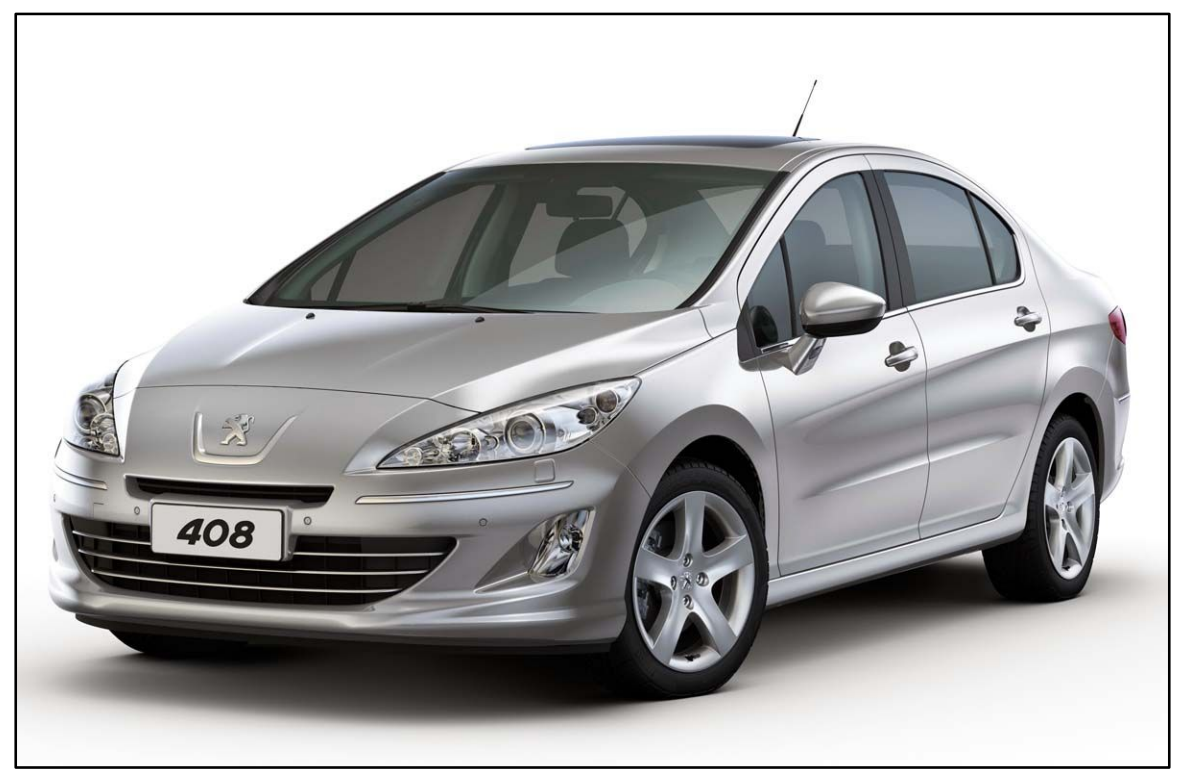

Figura 3.4: Peugeot 408 -Veículo utilizado na segunda fase de testes em dinamômetro

Tabela 3.3: Principais características técnicas do Peugeot 408.

\begin{tabular}{|c|c|c|c|}
\hline \multicolumn{2}{|l|}{ MOTOR } & \multicolumn{2}{|c|}{ TRANSMISSAO E VELOCIDADE } \\
\hline Código & $16 \mathrm{~V} \mathrm{THP}$ & Transmissão & Tiptronic \\
\hline Ciclo & Otto & Marchas & 6 \\
\hline Combustível & Gasolina & Velocidade Máxima & $215 \mathrm{~km} / \mathrm{h}$ \\
\hline Cilindrada Total (cm3) & 1598 & $\begin{array}{l}\text { Aceleração de 0-100 } \\
\mathrm{km} / \mathrm{h}(\mathrm{s})\end{array}$ & 9,2 \\
\hline Diâmetro x Curso (mm) & $77 \times 88,5$ & \multicolumn{2}{|c|}{ CONSUMO DE COMBUSTÍVEL } \\
\hline $\begin{array}{l}\text { Potencia Máxima, CEE } \\
(\mathrm{kW})\end{array}$ & 121 & Urbano $(1 / 100 \mathrm{~km})$ & 11,9 \\
\hline $\begin{array}{l}\text { Regime de Potencia } \\
\text { Máximo (rpm) }\end{array}$ & 6000 & $\begin{array}{l}\text { Extra urbano }(1 / 100 \\
\mathrm{km})\end{array}$ & 7,6 \\
\hline $\begin{array}{l}\text { Torque Máximo, CEE } \\
\text { (N.m) }\end{array}$ & 240 & Combinado $(1 / 100 \mathrm{~km})$ & 8,2 \\
\hline $\begin{array}{l}\text { Regime de Torque Máximo } \\
\text { (rpm) }\end{array}$ & 1400 & $\begin{array}{l}\text { Emissões de CO2 } \\
(\mathrm{g} / \mathrm{km})\end{array}$ & 190 \\
\hline Combustível & Sem chumbo & $\begin{array}{l}\text { Capacidade do tanque } \\
\text { (litros) }\end{array}$ & 60 \\
\hline Catalisador & Sim & \multicolumn{2}{|c|}{ AERODINAMICA } \\
\hline \multicolumn{2}{|l|}{ MASSA } & Área $\left(\mathrm{m}^{2}\right)$ & 2,55 \\
\hline Peso bruto $(\mathrm{kg})$ & 1527 & $\begin{array}{l}\text { Coeficiente de arrasto } \\
(\mathrm{Cx})\end{array}$ & 0,308 \\
\hline Peso máximo de carga $(\mathrm{kg})$ & - & Pneus & $225 / 45 \mathrm{R} 17$ \\
\hline Reboque (kg) & - & & \\
\hline Massa máxima $(\mathrm{kg})$ & - & & \\
\hline
\end{tabular}




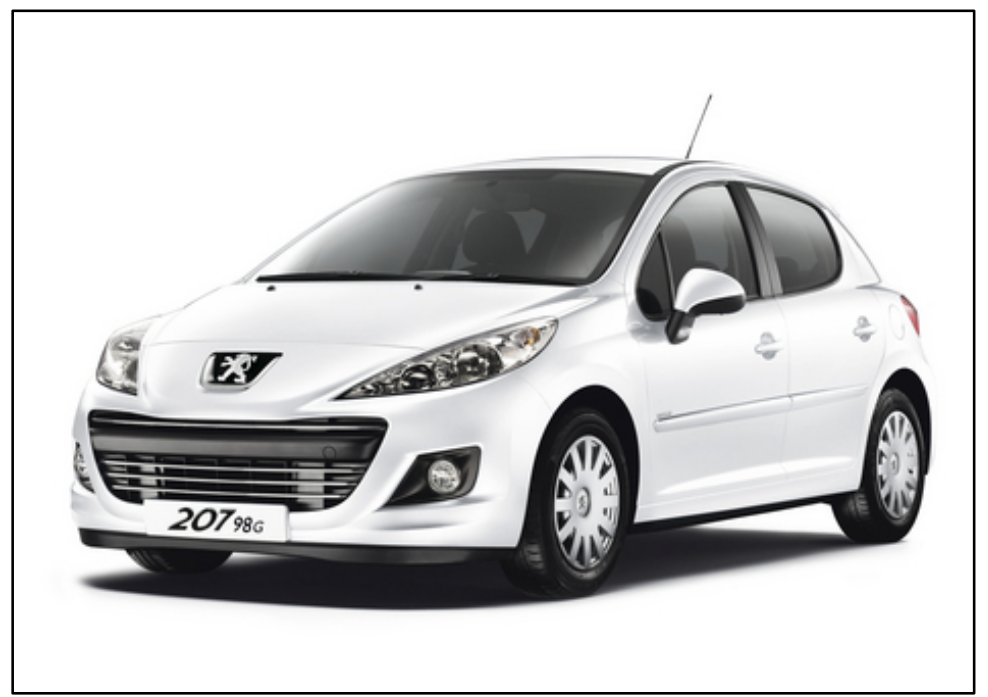

Figura 3.5: Peugeot 207 - utilizado na terceira fase de testes.

Tabela 3.4: Principais características técnicas do Peugeot 207 hp.

\begin{tabular}{|c|c|c|c|}
\hline \multicolumn{2}{|l|}{ MOTOR } & \multicolumn{2}{|c|}{ TRANSMISSÃO E VELOCIDADE } \\
\hline Código & $16 \mathrm{~V} \mathrm{THP}$ & Transmissão & Mecânico \\
\hline Ciclo & Otto & Marchas & 5 \\
\hline Combustível & Gasolina & Velocidade Máxima & $210 \mathrm{~km} / \mathrm{h}$ \\
\hline Cilindrada Total $(\mathrm{cm} 3)$ & 1598 & $\begin{array}{l}\text { Aceleração de 0-100 } \\
\mathrm{km} / \mathrm{h}(\mathrm{s})\end{array}$ & 8,1 \\
\hline Diâmetro x Curso (mm) & $77 \times 88,5$ & \multicolumn{2}{|c|}{ CONSUMO DE COMBUSTÍVEL } \\
\hline $\begin{array}{l}\text { Potencia Máxima, CEE } \\
(\mathrm{kW})\end{array}$ & 115 & Urbano $(1 / 100 \mathrm{~km})$ & 9,27 \\
\hline $\begin{array}{l}\text { Regime de Potencia } \\
\text { Máximo (rpm) }\end{array}$ & 5800 & $\begin{array}{l}\text { Extra urbano }(1 / 100 \\
\mathrm{km})\end{array}$ & 5,56 \\
\hline $\begin{array}{l}\text { Torque Máximo, CEE } \\
\text { (N.m) }\end{array}$ & 239 & Combinado (1/100 km) & 7,02 \\
\hline $\begin{array}{l}\text { Regime de Torque Máximo } \\
\text { (rpm) }\end{array}$ & 1400 & $\begin{array}{l}\text { Emissões de CO2 } \\
(\mathrm{g} / \mathrm{km})\end{array}$ & 166 \\
\hline Combustível & Sem chumbo & $\begin{array}{l}\text { Capacidade do tanque } \\
\text { (litros) }\end{array}$ & 50 \\
\hline Catalisador & Sim & \multicolumn{2}{|c|}{ AERODINAMICA } \\
\hline \multicolumn{2}{|l|}{$M A S S A$} & Área $\left(\mathrm{m}^{2}\right)$ & 2,12 \\
\hline Peso bruto $(\mathrm{kg})$ & 1280 & $\begin{array}{l}\text { Coeficiente de arrasto } \\
(\mathrm{Cx})\end{array}$ & 0,310 \\
\hline Peso máximo de carga (kg) & 373 & Pneus & 205/45 R17 \\
\hline Reboque (kg) & 1150 & - & - \\
\hline Massa máxima $(\mathrm{kg})$ & 2430 & - & - \\
\hline
\end{tabular}




\subsection{Ensaios de acúmulo de quilometragem}

A Figura 3.6 apresenta esquematicamente o arranjo experimental utilizado para realização dos ensaios no dinamômetro de chassis. Neste esquema estão representados, além das grandezas básicas de desempenho medidas através do próprio dinamômetro, os pontos onde foram feitas outras medições necessárias para a conclusão dos testes.

No dinamômetro de chassis foi adaptado um sistema de aquisição das informações enviadas pela central eletrônica do veículo ao motor, além de um sistema robotizado responsável pelo controle do veículo em teste. Além disso, os testes contaram com o auxílio de um sistema de abastecimento automático de combustível.

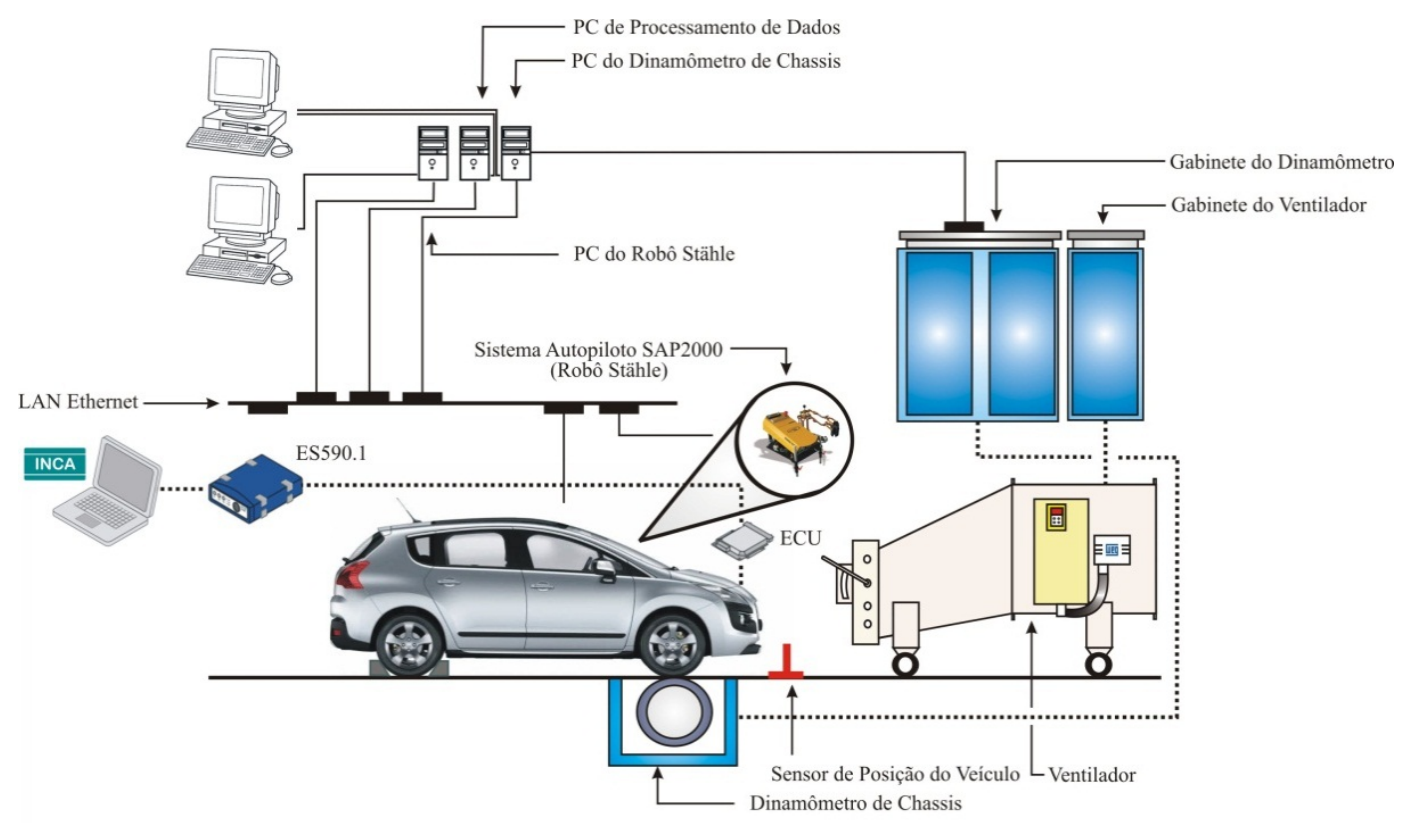

Figura 3.6: Esquema dos ensaios realizados no dinamômetro de chassis

A seguir são detalhados os equipamentos utilizados durante os ensaios realizados no dinamômetro de chassis. 


\subsubsection{Dinamômetro de chassis AVL - "ZÖLLNER 48"}

Tal sistema é utilizado para testes de veículos de dois eixos, motorizados com tração dianteira ou traseira. Tem a capacidade de carga máxima 4,5 ton por eixo. O sistema, apresentado na Figura 3.7 a seguir, foi desenvolvido para análise de emissões de exaustão, e é fabricado pela AVL South America, de acordo com as exigências especificadas na US EPA C 100081 T1 [8].

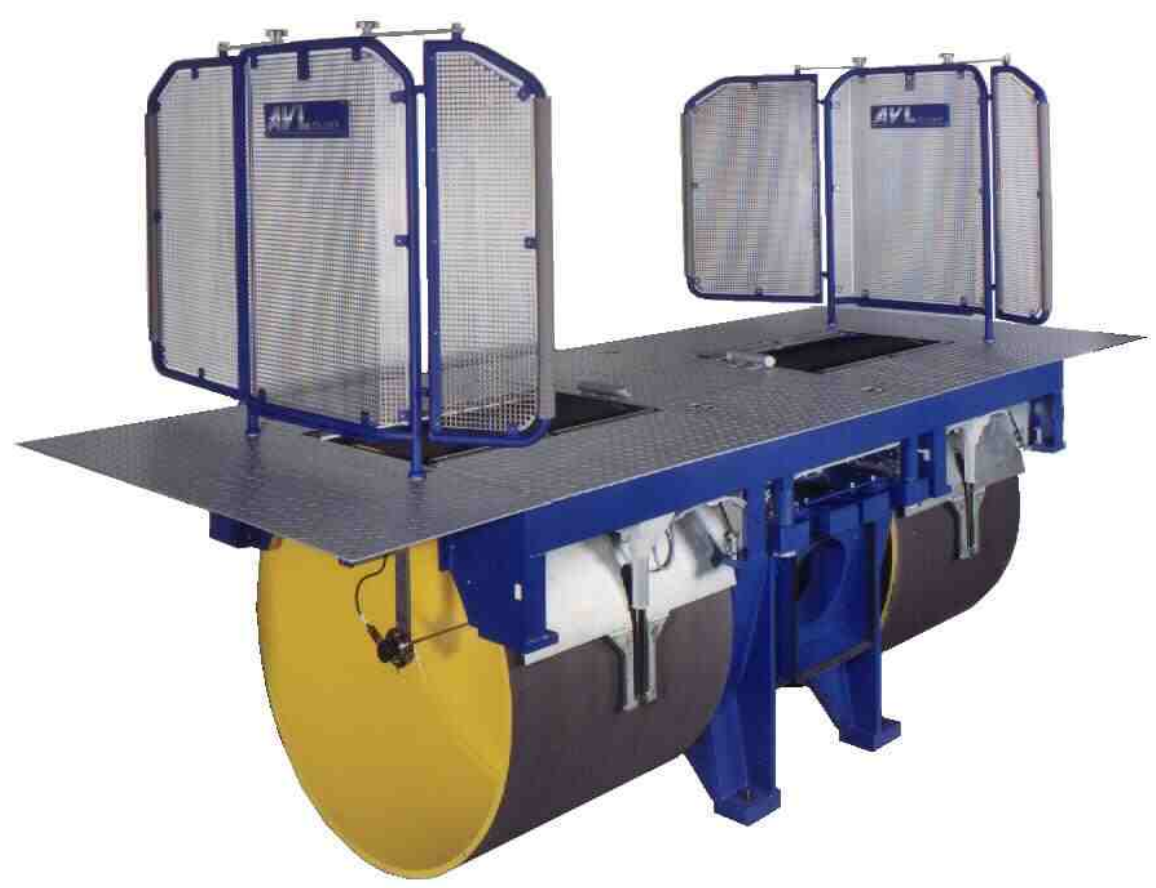

Figura 3.7: Dinamômetro de chassis utilizado nos ensaios

Este sistema foi projetado para simular veículos cujo peso se encontra na faixa de $454 \mathrm{~kg}$ a $5400 \mathrm{~kg}$ (peso total). O dinamômetro de chassis reproduz a inércia correspondente ao peso do veículo.

Entre os rolos contidos no dinamômetro de chassis, está situado um motor elétrico de corrente alternada (CA). Seu acionamento é realizado no estator do próprio motor. A fim de evitar a histerese provocada pelo atrito dos rolamentos, este motor realiza um movimento permanente de baixa velocidade, sobre seu eixo. Devido ao fato do dinamômetro de chassis conter um motor elétrico de corrente alternada, medições de desempenho em veículos mais potentes podem ser realizadas. 
A força de tração nominal do motor CA no modo de acionamento é de 5.870 $\mathrm{N}$ até $92 \mathrm{~km} / \mathrm{h}$. Já no gerador é de $5.987 \mathrm{~N}$ até os mesmos $92 \mathrm{~km} / \mathrm{h}$. A força de tração máxima do motor CA no modo de acionamento contínuo é $8.922 \mathrm{~N}$ até 92 $\mathrm{km} / \mathrm{h}$. No modo gerador é correspondente a $10.096 \mathrm{~N}$. A velocidade máxima de teste é $200 \mathrm{~km} / \mathrm{h}$.

Os valores de velocidade são medidos através de um gerador de pulsos incremental capaz de reconhecer o sentido da rotação. O valor de aceleração é facilmente obtido através da diferenciação do sinal de velocidade, proveniente do motor CA. Este valor é utilizado posteriormente para cálculos e simulação da inércia durante os testes.

O motor de corrente alternada situado entre os rolos do dinamômetro se encontra em balanço. Desta forma, a força transmitida ao rolo é repassada por um braço de alavanca a uma célula de carga que, por sua vez, digitaliza este sinal e o envia a um amplificador de medição. Com isso, obtém-se uma medida precisa do torque.

A medição da distância é derivada dos sinais de pulso vindos do gerador incremental. Quatro medições independentes de distância podem ser realizadas simultaneamente. Em cada nova partida a medição de distância é reajustada e volta ao valor zero.

\subsubsection{Simulação da inércia na estrada}

A inércia do dinamômetro de chassis é ajustada para corresponder ao peso real do veículo em teste. A inércia a ser simulada, mostrada na equação 3.1, é multiplicada pelo sinal da aceleração a fim de que se obtenha o ponto de ajuste da força de tração demandada. Os valores de costdown dos veículos testados foram enviados pela montadora.

A simulação de estrada é realizada conforme as fórmulas a seguir:

$$
\begin{gathered}
F=F_{t}+F_{0}+F_{1} v+F_{2} v^{n}+I_{w} * \frac{d v}{d t} \\
F_{t}=g R_{w} \operatorname{sen}(\alpha) \\
I_{w}=R_{w}-R_{g}
\end{gathered}
$$


Onde:

$F$ : força de Tração.

$g$ : aceleração da gravidade igual a $9,81 \mathrm{~m} / \mathrm{s}^{2}$.

$R_{w}$ : massa de referência do veículo em teste $(\mathrm{kg})$

$F_{t}$ : força de Tração para vencer o gradiente da estrada

$F_{0}$ : força de Tração independente da velocidade $\mathrm{N}$

$F_{1}$ : parcela com dependência linear da velocidade

$v$ : velocidade

$F_{2}$ : força de tração

$n$ : expoente da variável $(1<\mathrm{n}<3)$

$R_{g}$ : inércia básica do dinamômetro de chassis

$I_{w}$ : inércia a ser simulada seletivamente

$\frac{d v}{d t}:$ aceleração

\subsubsection{Autopiloto STHÄLE SAP 2000}

O robô autopiloto SAP 2000, fabricado pela empresa alemã STHÄLE, é controlado por um computador para testes de direção de veículos em dinamômetros de chassis. O ciclo de acionamento específico é definido pelo operador através de software, em um computador remoto, via interface RS-232 ou LAN. 


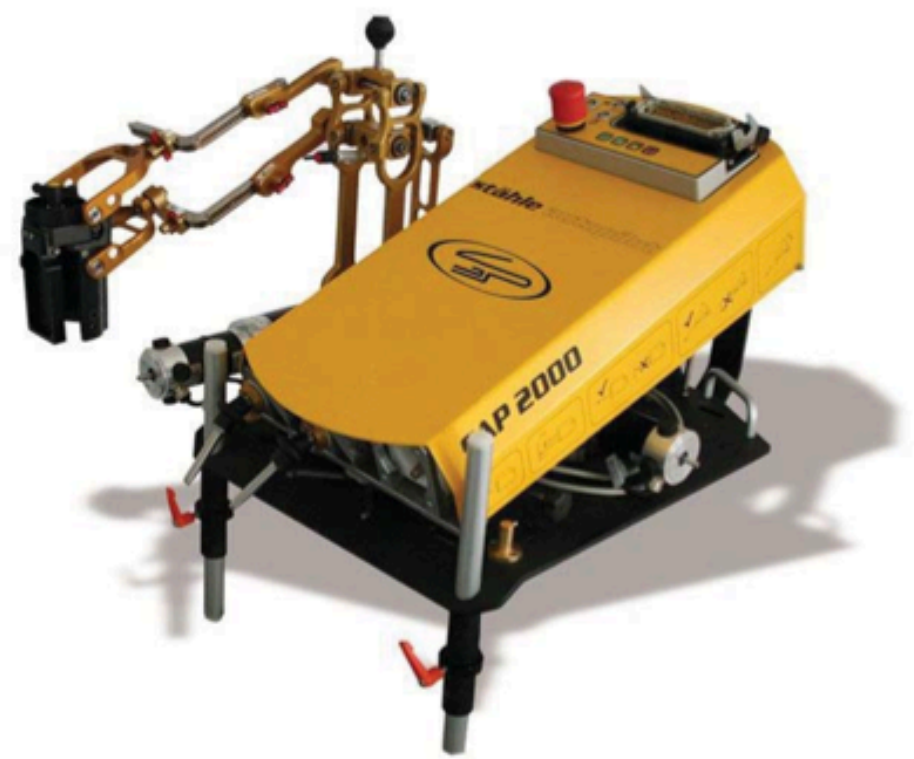

Figura 3.8: Autopiloto SAP 2000

A Tabela 3.5 a seguir, apresenta as características técnicas do robô SAP 2000, utilizado durante os ensaios realizados no dinamômetro de chassis. Este sistema permite alto grau de precisão e repetibilidade, o que garante confiabilidade nos resultados obtidos. A cada teste realizado com um novo veículo, é necessário que o ciclo de calibração, ou aprendizado, seja novamente realizado. Este ciclo é importante para que o robô piloto determine as características de desempenho de cada veículo, como curso dos pedais de aceleração, embreagem e freio, assim como a posição relativa a cada marcha do automóvel testado. 
Tabela 2.5: Principais características do autopiloto SAP 2000.

\begin{tabular}{|c|c|c|c|}
\hline \multicolumn{2}{|l|}{ Geral } & \multicolumn{2}{|l|}{ Atuador da marcha } \\
\hline Peso Total & $30 \mathrm{~kg}$ & Sistema de atuação & Motor elétrico \\
\hline Controle de Tensão do atuador & $35 \mathrm{~V} \mathrm{CC}$ & Curso da marcha & $250 \mathrm{~mm}$ max. \\
\hline Temp. de Operação & $-40^{\circ} \mathrm{C}$ até $80^{\circ} \mathrm{C}$ & Curso lateral & $200 \mathrm{~mm}$ max. \\
\hline Temp. de Armazenamento & $-30^{\circ} \mathrm{C}$ até $80^{\circ} \mathrm{C}$ & Força & $250 \mathrm{~N}$ max. \\
\hline Potência de Operação & 110/230 VCA, 600 watts & Velocidade & $0,6 \mathrm{~m} / \mathrm{s} \max$. \\
\hline \multirow{4}{*}{ Componentes do controlador } & Módulo de sinal & Posições automáticas da marcha & P-R-N-D-4-3-2-1 \\
\hline & Módulo de Energia & Posições manuais da marcha & R-N-1-2-3-4-5-6 \\
\hline & Ventilador & Sequencial + Tiptronic & Manual - Neutro \\
\hline & Computador & Velocidade & $0,45 \mathrm{~m} / \mathrm{s} \max$. \\
\hline \multicolumn{2}{|l|}{ Atuador da Embreagem } & \multicolumn{2}{|l|}{ Atuador do freio SAP 2000} \\
\hline Sistema de atuação & Motor elétrico & Sistema de atuação & Motor elétrico \\
\hline Curso & $200 \mathrm{~mm}$ max. & Curso & $150 \mathrm{~mm}$ max. \\
\hline Força & $200 \mathrm{~N}$ max. & Força & $350 \mathrm{~N}$ max. \\
\hline Velocidade & $0,35 / 0,5 \mathrm{~m} / \mathrm{s} \max$ (engatar/liberar) & Velocidade & $0,3 \mathrm{~m} / \mathrm{s}$ max. \\
\hline \multicolumn{2}{|l|}{ Atuador do acelerador } & \multicolumn{2}{|l|}{ Entradas de Velocidade } \\
\hline Sistema de atuação & Motor elétrico & Entrada analógica de tensão & $0-10 \mathrm{~V}$, isolado oticamente \\
\hline Curso & $150 \mathrm{~mm}$ max. & Frequência de entrada de pulso & $0,5 \mathrm{~Hz}$ até $500 \mathrm{kHz}$ \\
\hline Força & $100 \mathrm{~N}$ max. & Tensão de entrada de pulso & $\pm 75 \mathrm{~V}$ \\
\hline Velocidade & $0,45 \mathrm{~m} / \mathrm{s} \max$. & Faixa recomendável de pulso & 3 pulsos/polegada \\
\hline
\end{tabular}




\subsubsection{Módulos ETAS ES590.1 e ES581.3}

Os módulos ETAS ES590.1 e ES581.3 são os hardwares responsáveis por fazer a comunicação da Unidade de Controle Eletrônica (UCE) com o computador utilizado para leitura e/ou troca das variáveis de interesse contidas nesta UCE. Atualmente, existem dois tipos de unidade de controle: a central de desenvolvimento, ou ETK, que permite que modificações sejam realizadas na calibração, e a central eletrônica do tipo "caixa fechada". Esta segunda trata-se de uma unidade de produção, que permite somente que suas variáveis sejam lidas e gravadas, porém não alteradas durante os ensaios.

Durante os ensaios realizados para a conclusão do presente trabalho, três diferentes veículos foram utilizados. Os veículos Peugeot 3008 e 408 eram equipados com UCE's do tipo “caixa fechada”. Já o Peugeot 207 hp, utilizava uma central eletrônica do tipo ETK.

Pode-se observar o módulo ES590.1, da série ES59x através da Figura 3.9 a seguir.

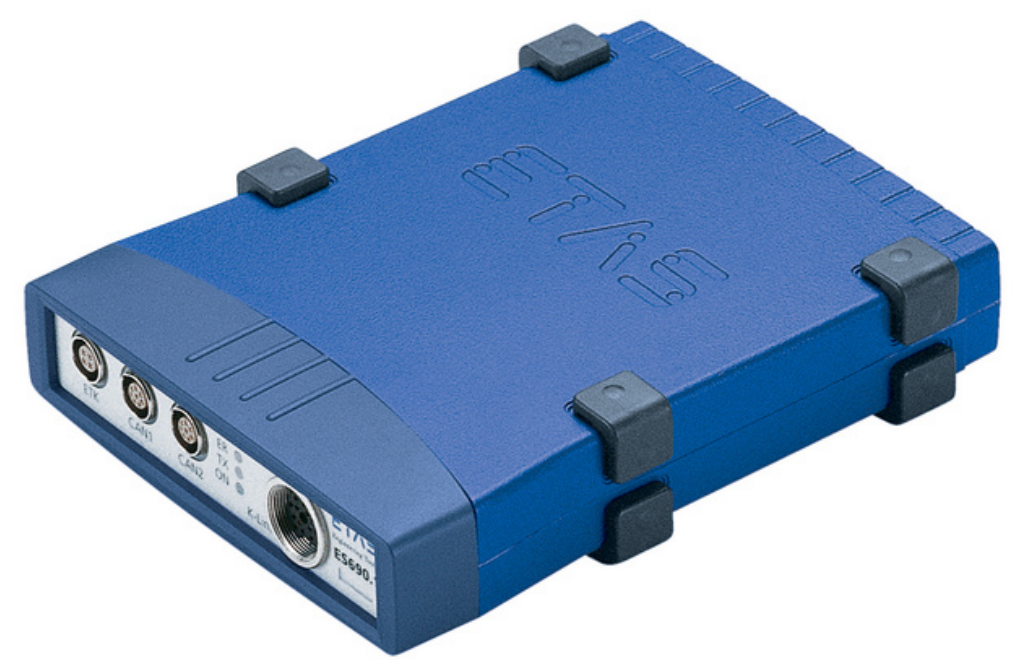

Figura 3.9: Interface de comunicação ETAS 590.1

Sua comunicação pode ser feita através de Ethernet/XETK, ETK, FlexRay, CAN, LIN e linha K. Esta interface também é utilizada para calibração de UCE, diagnósticos e programação de flash das centrais eletrônicas do tipo ETK. Este módulo foi utilizado somente quando o veículo testado era equipado com uma UCE do tipo aberta. 
Já quando o motor testado utilizava a UCE do tipo "caixa fechada", o módulo usado foi o ES581.3, mostrado na Figura 3.10. Este módulo conecta veículos CAN (Controller Area Network) ao computador responsável por armazenar os dados através de uma porta USB, que estabelece uma conexão CAN direta.

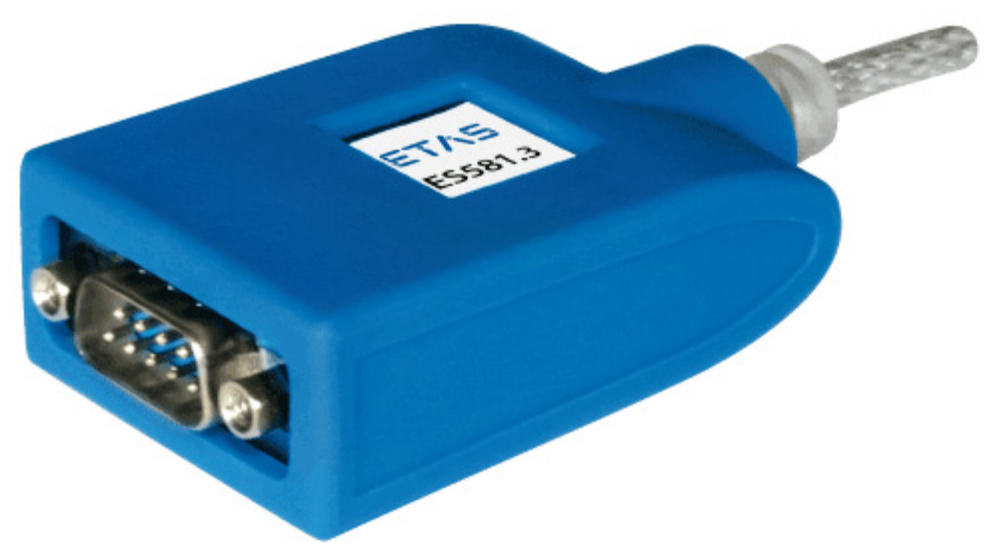

Figura 3.10: Interface de comunicação ETAS 581.3

O monitoramento/armazenamento dos dados é realizado através da interface INCA.

\subsubsection{Ventilador de resfriamento}

Para os testes realizados no dinamômetro de chassis, um ventilador axial externo de resfriamento se faz necessário. O ventilador, mostrado na Figura 3.11, contém um motor elétrico trifásico 220/380/440 volts e é acionado pelo controlador do dinamômetro. 

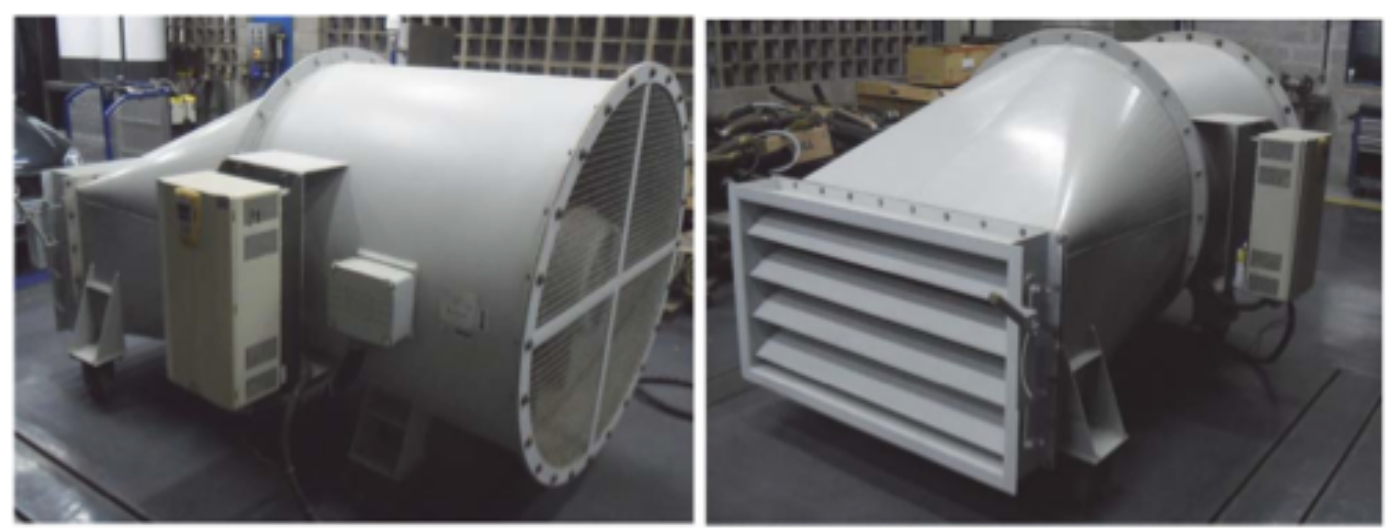

Figura 3.11: Vistas lateral e frontal do ventilador de resfriamento.

A velocidade do ventilador deve ser proporcional a do dinamômetro. Sendo assim, para que o ventilador tenha sua velocidade variada de acordo com o ciclo programado no dinamômetro, seu motor elétrico trabalha em conjunto com um inversor de frequência. A Tabela 3.6 a seguir mostra algumas das características do ventilador.

Tabela 3.6: Principais características do ventilador de resfriamento.

\begin{tabular}{|l|c|}
\hline \multicolumn{2}{|c|}{ Aspéctos Técnicos } \\
\hline Referência & AXIAL \\
\hline Modelo & B-12 \\
\hline Tipo & RAL 9002 \\
\hline Acabamento & IP 23 \\
\hline Classe de proteção mínima & 490 \\
\hline Tamanho & 4 Tubos \\
\hline Arranjo & 100000 \\
\hline Vazão (m3/h) & 654 \\
\hline Pressão estática (Pa) & 1200 \\
\hline Pressão total (Pa) & 22,76 \\
\hline Velocidade de descida (m/s) & 45 \\
\hline Potência Consumida (Cv) & 1760 \\
\hline RPM ventilador & $60 / 1760$ \\
\hline Motor (Cv/RPM) & 102 \\
\hline Nível de Ruído a 1 (dBA) & \\
\hline
\end{tabular}




\subsubsection{Sistema de controle e aquisição de dados}

O sistema de controle e aquisição de dados é separado em duas partes nesta seção. A relativa ao controle do dinamômetro / robô piloto, e a parte relativa as informações contidas na unidade de controle eletrônica. Estes sistemas serão descritos ao longo da seção. É importante que se tenha certeza da confiabilidade dos dados gravados. Desta forma pode-se afirmar que o percurso percorrido pelo veículo no dinamômetro de chassis é o mais próximo possível do escrito no programa garantindo, assim, uma boa repetibilidade nos ensaios realizados.

\subsubsection{Interface do usuário AVL - ZÖLLNER}

A operação deste sistema ocorre através de uma interface "homem máquina" intuitiva. A interface gráfica pode ser visualizada através da Figura 3.12: 


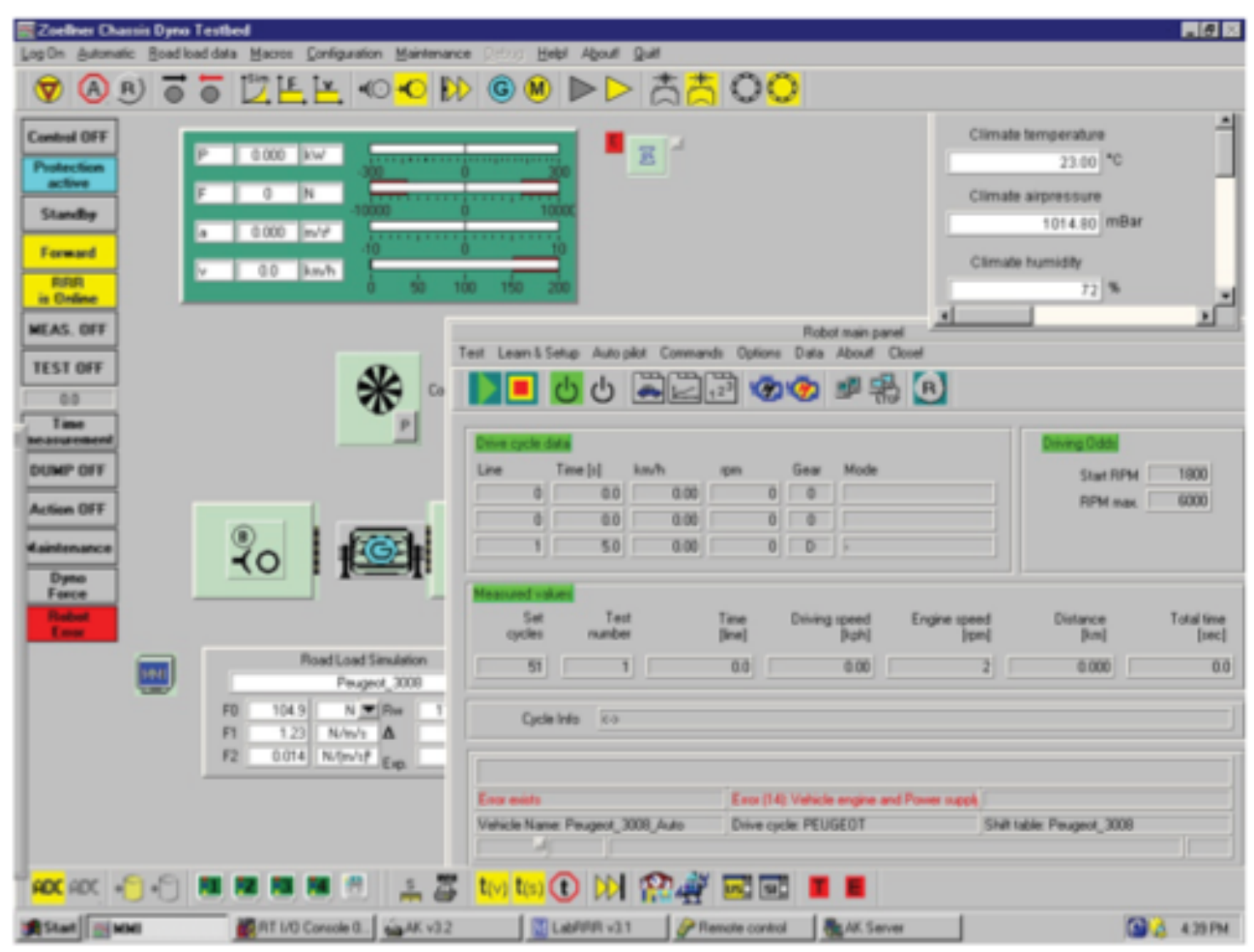

Figura 3.12: Interface gráfica AVL ZÖLLNER

\subsubsection{Interface do usuário Autopiloto SAP 2000}

Através deste software, é possível que se programe o método de condução do veículo, assim como o monitoramento e controle do robô. Desta forma garantese que o ciclo programado está sendo devidamente executado. A programação do ciclo pode ser feita "segundo a segundo" ou por programação de "velocidade por tempo". A primeira maneira é utilizada para ciclos muito dinâmicos e tem um maior custo computacional, uma vez que para cada segundo se exige uma linha de programação de velocidade. A segunda maneira, utilizada nos ensaios, é programada por blocos de velocidade. Sendo assim, com uma linha de programação se estipula o intervalo tempo necessário para uma velocidade ou o intervalo de tempo entre duas velocidades.

Desta forma, rampas de aceleração positivas ou negativas podem ser programadas com liberdade por ambos os métodos. A interface está mostrada na Figura 3.13. 


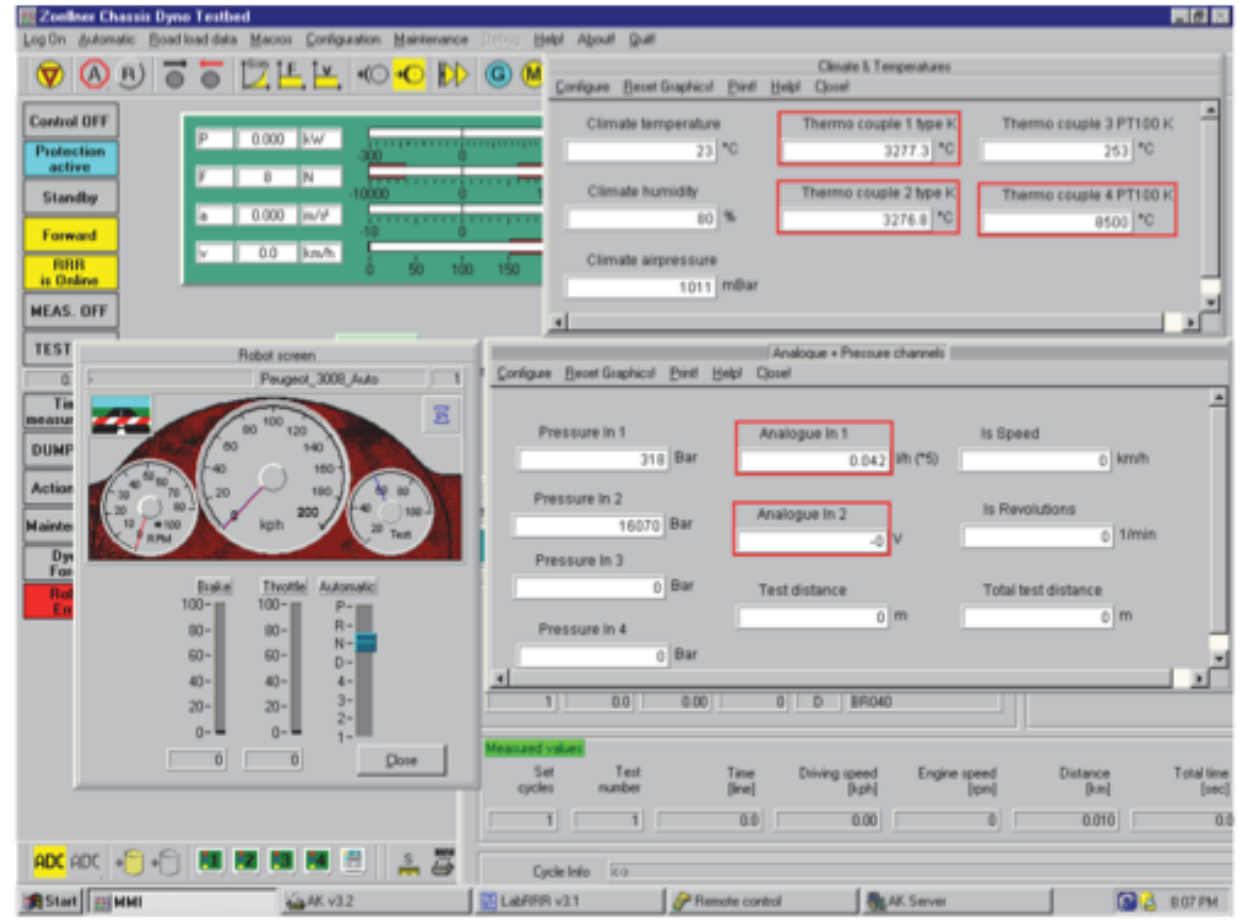

Figura 3.13: Interface gráfica do usuário Autopiloto SAP 2000.

As principais características deste programa estão mencionadas a seguir:

- Programa operacional acionado por menu.

- Responsável por fazer o auto aprendizado do robô piloto.

- Procedimento de aprendizado para seleção de posição da embreagem.

- Direção manual com robô piloto.

- Permite que os ciclos mais simples sejam escritos sem um conhecimento profundo de programação.

- Criação de ciclos de direção utilizando sistema de dialogo ou arquivos ASCII.

- Ciclos de direção podem ser descarregados via computador host remoto.

- Ciclo pode ser iniciado/parado a qualquer momento.

- Dimensões de controle podem mudar linha a linha em um ciclo de direção.

- Força de embreagem programáveis.

- Contém ciclos pré-definidos, tais como: FTP 72 e FTP 75, FTP 505, ciclos cidade US e estrada US, cidade de Nova Iorque, AMA/EPA, EUDC e modo 10. 
A Figura 3.14 a seguir ilustra parte de um ciclo "velocidade $\times$ tempo". A linha em tom de cinza representa o ciclo programado, enquanto a vermelha demonstra o ciclo que está sendo realizado pelo veículo em teste.

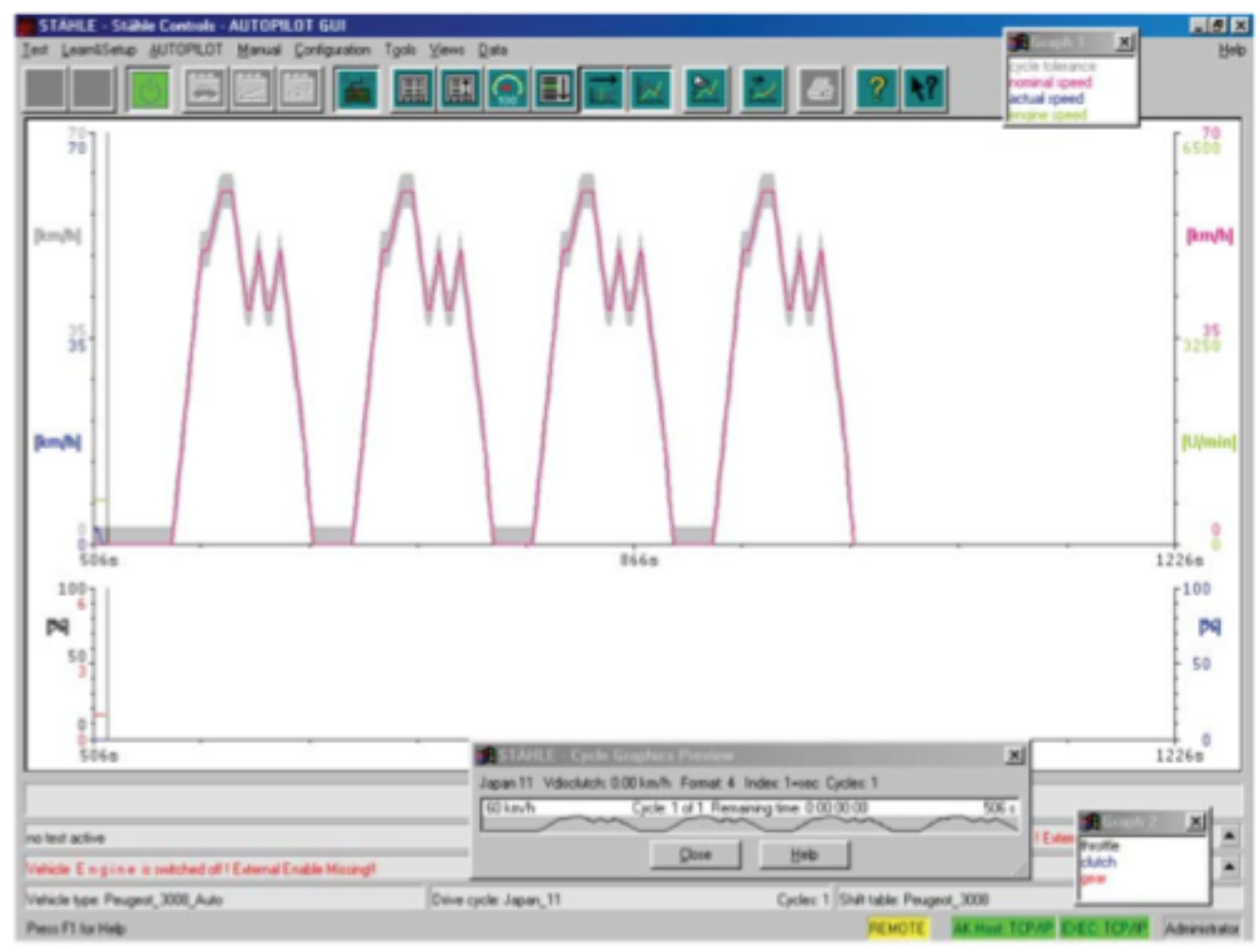

Figura 3.14: Parte do ciclo "velocidade $\times$ tempo", elaborado para o veículo no dinamômetro de chassis.

\subsubsection{Interface ETAS - INCA}

As ferramentas oferecidas pelo INCA são utilizadas para desenvolvimento de UCE e testes, tanto de calibração, quanto de validação de sistemas eletronicamente controlados no veículo, em bancadas de teste ou em ambientes simulados dentro do próprio computador.

Este programa pode oferecer uma vasta variedade de funções incluindo précalibração de modelos de funções no computador, programação de flash da central eletrônica, análise de dados medidos, assim como otimização automatizada de parâmetros da UCE. A calibração e medição dos dados gerados podem ser processadas e validadas continuamente. 
A partir do arquivo da calibração contido na central eletrônica, enviado pela PSA Peugeot-Citroën, é possível que se programe um experimento, ilustrado na Figura 3.15, a seguir, para monitoramento somente das variáveis de interesse.

Portanto, durante o projeto, o programa teve como principal função o monitoramento e armazenamento contínuo destas variáveis, ao longo dos ensaios. Desta forma, uma análise mais detalhada dos dados se fez possível, a fim de ajudar na compreensão do problema de depósitos nos injetores de combustível.

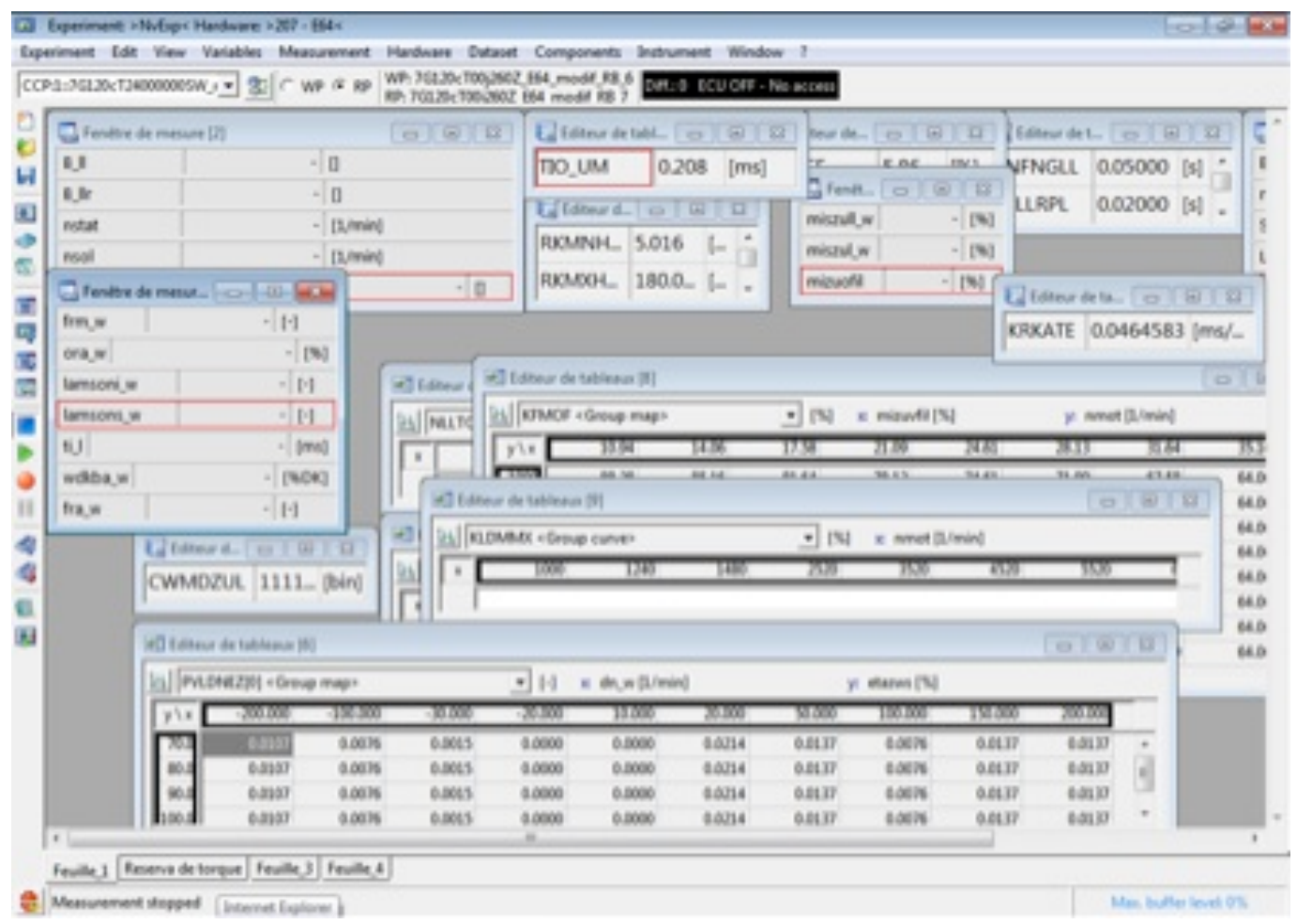

Figura 3.15: Interface de leitura das variáveis da UCE no INCA.

\subsection{Bancada de medição de vazão}

Para desenvolver as análises quantitativas da perda de vazão de combustível pelos bicos injetores, foi elaborada a bancada de testes, mostrada na Figura 3.16 a seguir. 


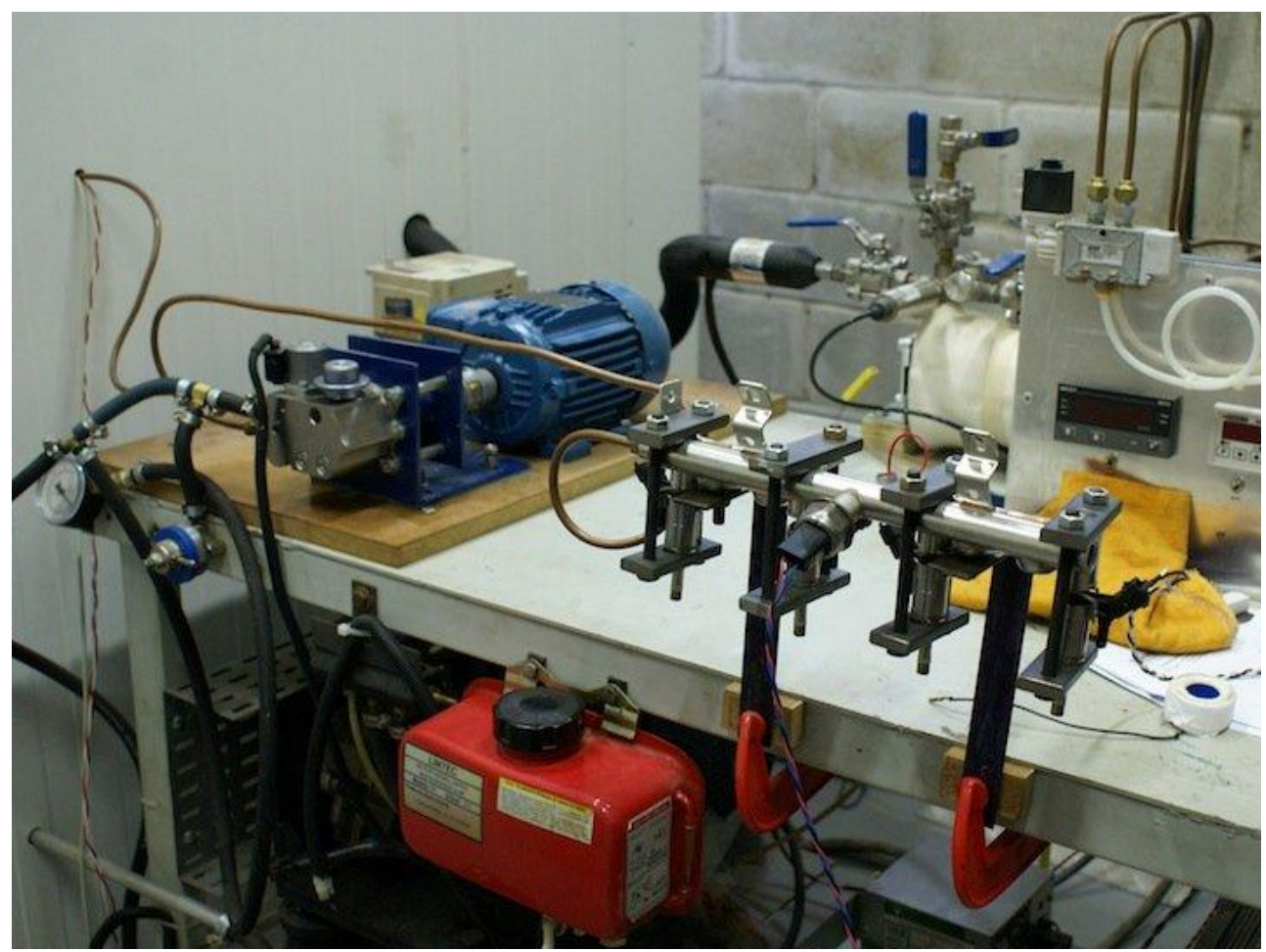

Figura 3.16: Bancada de testes de vazão dos injetores

Para garantir que o sistema utilizado fosse o mais próximo possível do real, o sistema implementado na bancada foi equivalente ao do veículo. Desta forma, foram utilizados componentes originais do motor EP6 CDTm, tais como bicos injetores, common rail, bombas de combustível de baixa e alta pressão, filtro de combustível e regulador de pressão. Porém, como a bomba de alta pressão é, normalmente, ligada ao eixo do motor, na montagem da bancada foi utilizado um motor elétrico e um inversor de frequência.

A seguir, os equipamentos utilizados durante os ensaios de medição de vazão através dos injetores serão detalhados.

\subsubsection{Bico injetor}

O injetor de combustível utilizado ao longo dos ensaios é do tipo solenoide on-off com múltiplos furos. Tendo em vista que estes bicos injetores, contidos no motor EP6 CDTm de injeção direta, são dispositivos eletromagnéticos de baixa 
impedância, o perfil de corrente enviado pelo módulo de injeção eletrônica necessita ser do tipo "peak and hold", ilustrado na Figura 3.17, abaixo.

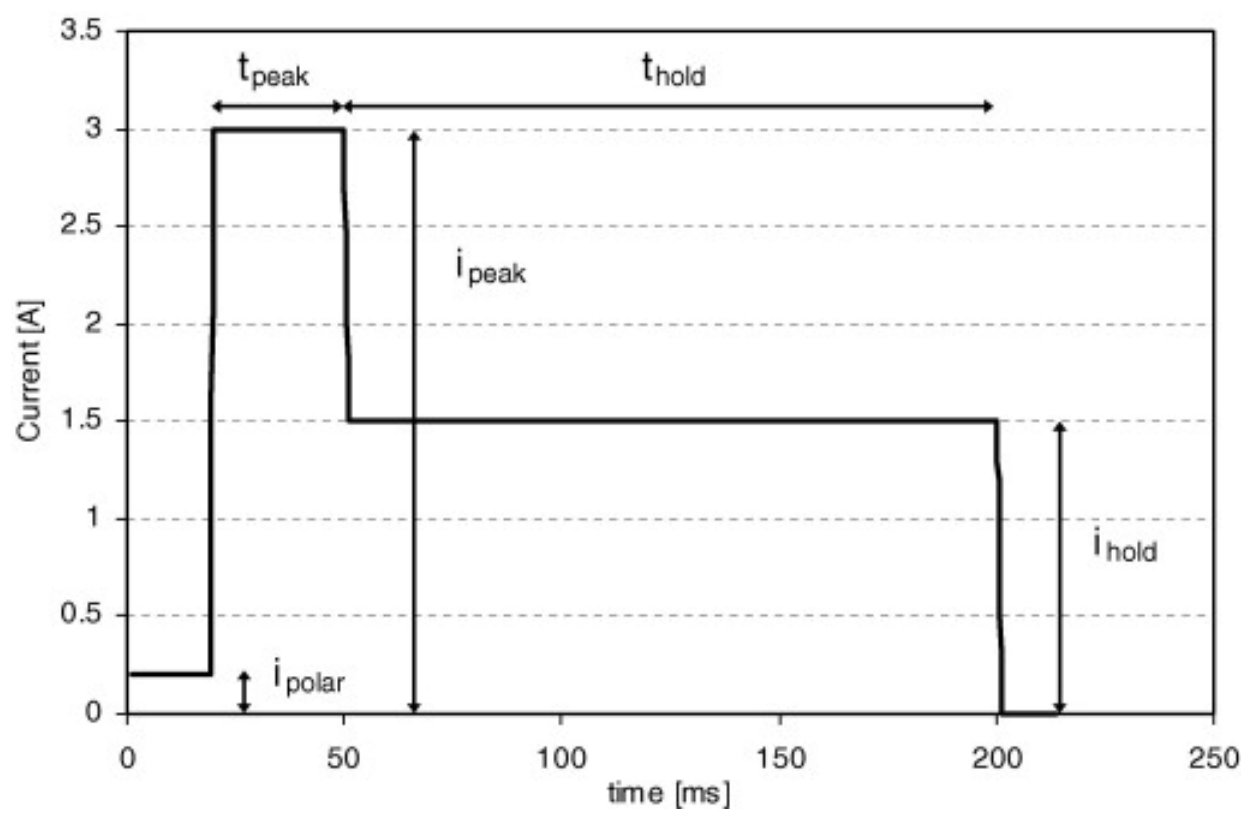

Figura 3.17: Esquema de um perfil de corrente do tipo "peak and hold".

O primeiro pico de tensão enviado ao injetor, é responsável por vencer a inércia e empurrar o êmbolo ou núcleo para cima. Isto permite que uma válvula, pressionada por mola, se desloque de sua sede permitindo que o combustível seja pulverizado na câmara de combustão. O volume de combustível injetado é proporcional ao tempo de abertura da válvula. Neste caso, relativo ao incremento no tempo de "hold", uma vez que o tempo do "peak" é constante.

Na situação de operação natural de um veículo, após receber as informações dos diversos sensores sobre as condições de funcionamento do motor, o módulo de injeção eletrônica define o tempo de injeção, enviando um sinal ao bico injetor.

Na bancada desenvolvida para os testes de vazão, os tempos de abertura do bico são definidos anteriormente aos testes e são programados no módulo de injeção EFS, juntamente com o gerador de funções aleatórias. 


\subsubsection{Bomba elétrica de combustível (baixa pressão)}

A bomba elétrica de combustível é responsável por garantir que a linha de combustível seja pressurizada com aproximadamente 4,5 bar até o regulador de pressão.

A bomba de baixa pressão utilizada nos ensaios, mostrada na Figura 3.18 abaixo, é do tipo "turbina". Este tipo de bomba de combustível conta com um anel impulsor acoplado a um motor elétrico. Desta maneira, as lâminas contidas neste anel empurram o combustível através da bomba, a medida que o impulsor gira. Como esta bomba não é do tipo "deslocamento positivo", não há produção de ondas de pulsos de pressão, o que faz com que a mesma possa operar de forma suave e silenciosa. Sua rotação de operação pode chegar a $7.000 \mathrm{rpm}$ e seu consumo de corrente é menor quando comparado a outros modelos.

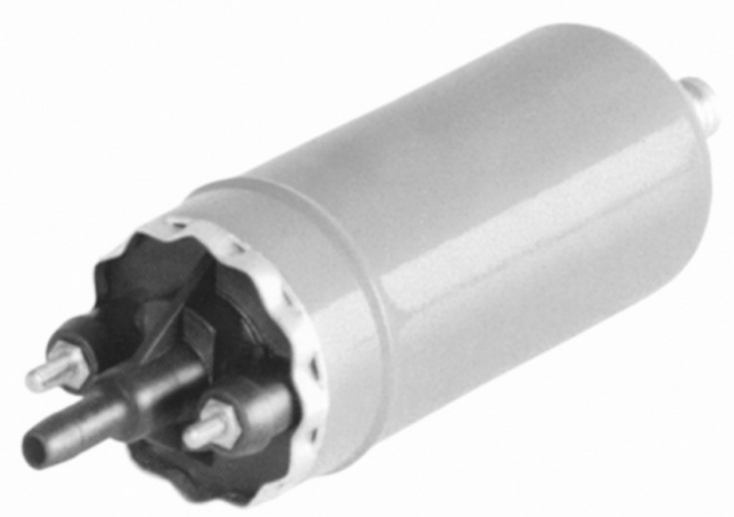

Figura 3.18: Imagem da bomba de baixa pressão.

Normalmente, estas bombas de baixa pressão trabalham imersas no tanque de combustível para que possam ser resfriadas pelo mesmo. No caso da bancada de testes de vazão, em função do curto tempo de operação dos testes, não houve esta necessidade. 


\subsubsection{Bomba mecânica de combustível (alta pressão)}

Para que a bancada de testes de vazão consiga reproduzir o funcionamento do motor utilizado nos veículos testados no dinamômetro de chassis, é preciso que a pressão de injeção chegue a valores consideravelmente altos, próximos a 140 bar. Para isso, foi utilizada uma bomba mecânica de deslocamento positivo, igual a existente no motor EP6 CDTm.

Seu princípio de funcionamento baseia-se no deslocamento de uma engrenagem interna (palheta) em relação à engrenagem externa (rotor), ou seja, a engrenagem interna gira excentricamente ao eixo da bomba. $\mathrm{Na}$ entrada da bomba se formam câmaras de sucção, entre os dentes da palheta e os dentes do rotor, que "puxam" o combustível para dentro da bomba. Em seguida, o fluxo de líquido é dividido pela meia-lua, que é fixa. Parte do fluxo de combustível é conduzido entre os dentes da palheta e a outra parte é conduzida entre os dentes do rotor. A meia-lua funciona como uma espécie de vedação entre a entrada e a saída da bomba.

$\mathrm{Na}$ etapa final, a palheta e o rotor voltam a se engrenar, reduzindo os espaços entre os dentes das engrenagens e expulsando o combustível pela conexão de saída da bomba.

\subsubsection{Sistema de controle}

O esquema, abaixo apresentando, demonstra o sistema de controle da pressão de injeção, assim como o sistema responsável pelo envio do sinal aos bicos injetores, e suas linhas de atuação. Os equipamentos responsáveis por fazer este controle estão detalhados ao longo da seção. 


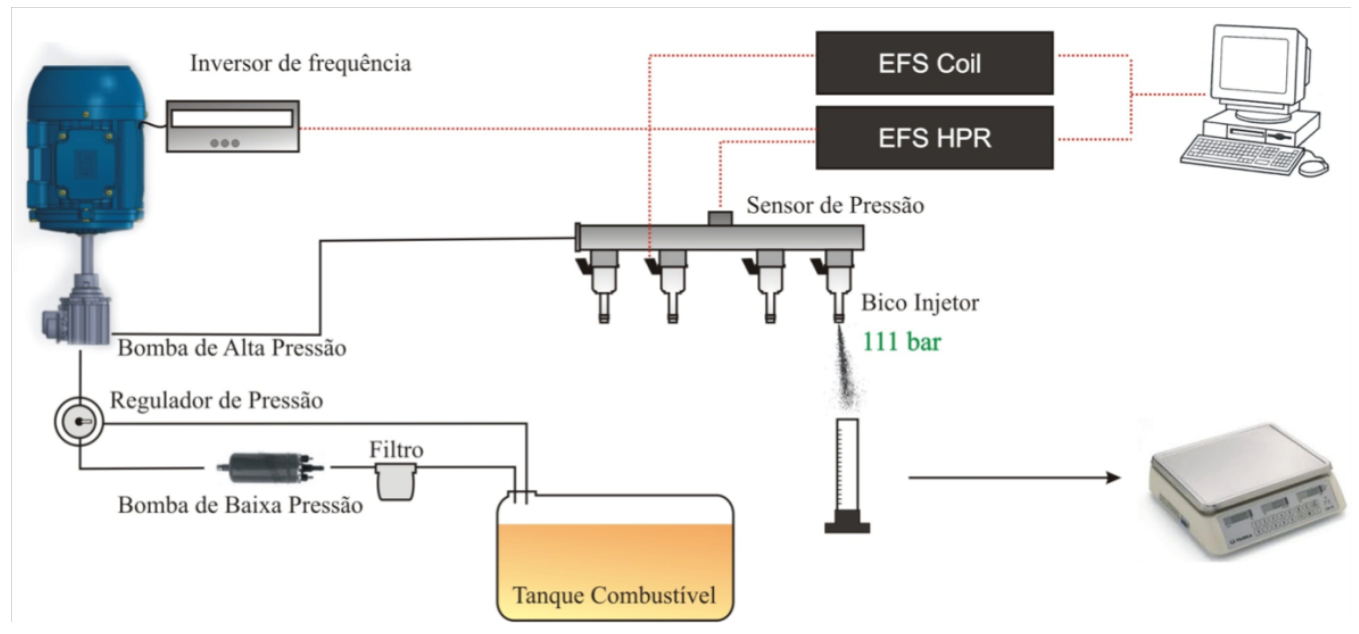

Figura 3.19: Esquemático da banca de vazão

\subsubsection{Módulo EFS High Pressure Regulator (HPR)}

O módulo EFS HPR tem como função assegurar a regulação de pressão no "common rail" contido no sistema de injeção de combustível. Este sistema é comandado por um computador, através de uma conexão serial RS485.

Além da tensão de alimentação de 115 Vac ou 230 Vac, a 50/60 Hz, o sistema requer uma alimentação adicional de 10 a $36 \mathrm{Vdc}$, simulando a bateria, para o comando dos atuadores.

O sistema é composto por:

- Uma placa CPU, responsável por ler a informação do sensor de pressão implementado no commom rail e a partir desta informação executar o ajuste numérico da pressão

- Uma placa de condicionamento do sensor de pressão

Sinais de entrada: $0-5 \mathrm{~V}$ ou $0-32 \mathrm{~mA}$

Alimentação de saída do sensor: $+5 \mathrm{~V}$ ou $+12 \mathrm{Vdc}$

A alimentação da placa de controle dos atuadores pode ser externa ou interna. Esta placa permite diferentes tipos de regulação de pressão:

- Regulação assíncrona no "common rail”.

- Regulação de saída da bomba de alta pressão. 
- Regulação de entrada da bomba de alta e saída da bomba de baixa pressão.

- Regulação de entrada da bomba de baixa pressão.

O HPR é conectado ao computador supervisor através de uma conexão RS485 (MODBUS), e as informações trocadas são:

- Valor de pressão configurado

- Tipo do atuador utilizado

- Estado de falhas do regulador

- Tempo do comando de medição de pressão

- Parâmetros dos sensores conectados (linearidade e escala completa)

- Medida de pressão instantânea

As especificações técnicas do módulo estão apresentadas na Tabela 3.7:

Tabela 3.7: Principais características do módulo EFS Pressure Regulator.

\begin{tabular}{|l|c|}
\hline Tipo de sensor & Escala do sensor configurável \\
\hline Faixa de regulação & 0 para o fundo de escala do sensor \\
\hline Precisão de regulação & $\pm 1 \%$ do fundo de escala \\
\hline Tipo de Regulação & PID numérico \\
\hline Interface de comunicação & RS 485 (protocolo MODBUS) \\
\hline $\begin{array}{l}\text { Tensão externa ou interna opcional } 3 \\
\text { de alimentação dos atuadores }\end{array}$ & 10 a 36 Vdc 10A. \\
\hline
\end{tabular}

\subsubsection{Módulo EFS Ipod Coil Injector Power Driver}

O módulo EFS 8427, ilustrado na Figura 3.20, tem como principal função o envio da tensão de acionamento de injetores eletromagnéticos. 


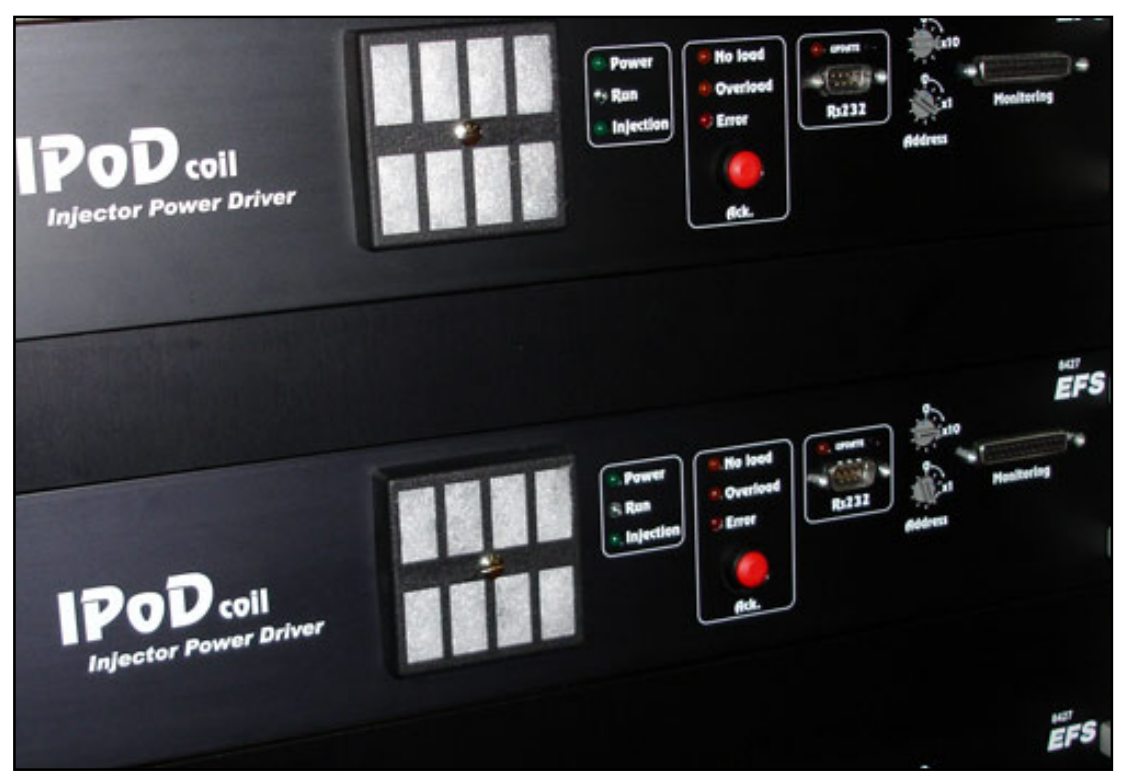

Figura 3.20: Imagem do módulo EFS Ipod Coil.

O Ipod Coil conta com uma interface gráfica que facilita o controle dos parâmetros de injeção. Desta forma, é possível que se projete, na bancada de testes de vazão, o perfil exato de corrente enviado aos injetores pela unidade de comando eletrônica, em condições normais de operação de um veículo.

$\mathrm{O}$ acionamento do injetor pode ser trigado de duas maneiras: internamente, devido a um gerador de pulsos existente no módulo, e externamente. Optou-se por acionar externamente através de um gerador de funções arbitrárias, descrito no decorrer desta seção. Sendo assim, um pulso com a duração de injeção pretendida era enviado ao EFS Ipod Coil, e o mesmo alterava o sinal recebido para o formato peak and hold característico do injetor utilizado nos testes.

A Figura 3.21 apresenta a tela de controle do software xIpod, utilizado para parametrizar o sistema de injeção utilizado na bancada de testes de vazão. 


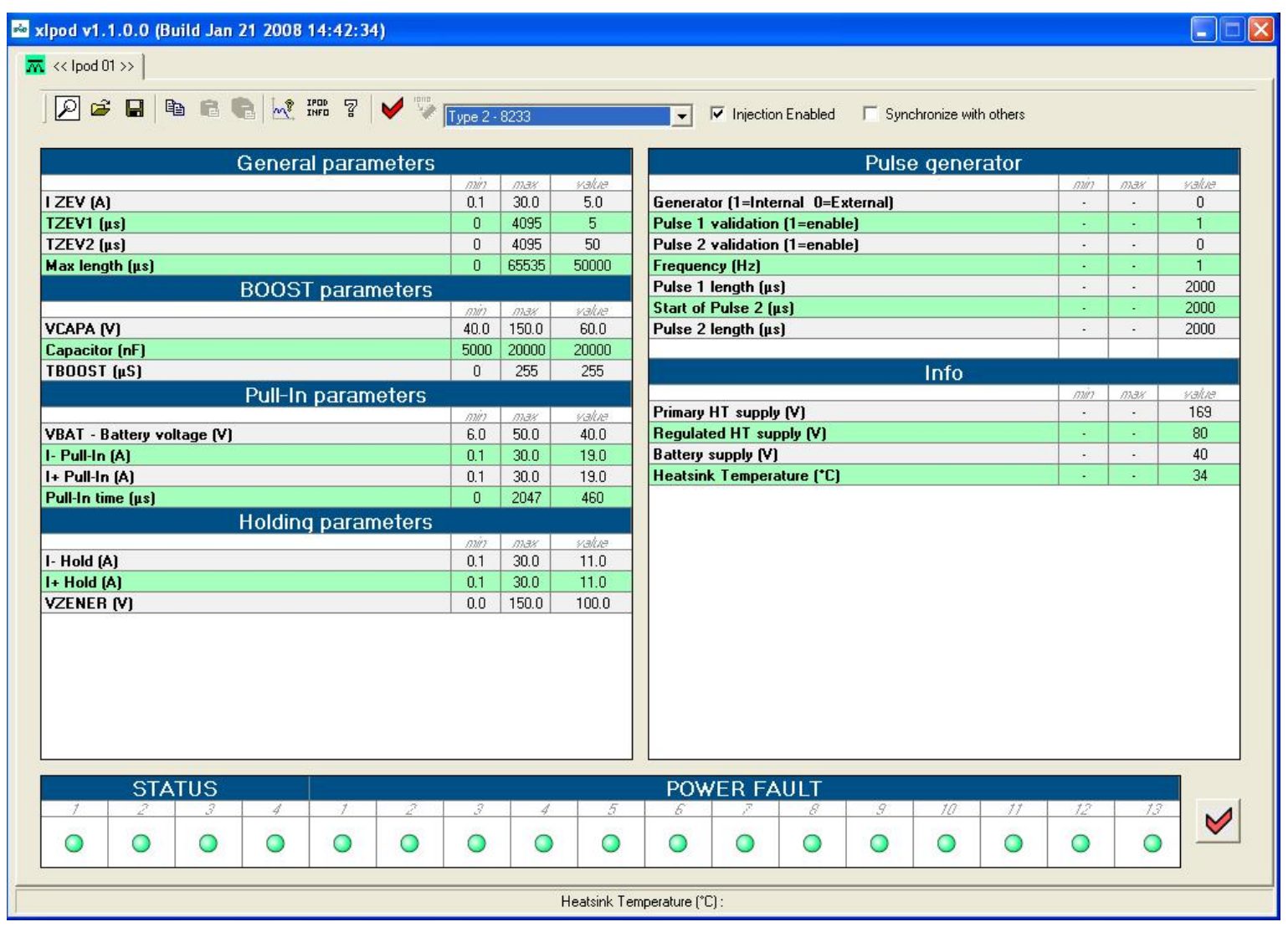

Figura 3.21: Tela de comando da interface de controle do módulo de controle da injeção, EFS Ipod Coil.

A Tabela 3.8 apresenta as especificações técnicas do módulo EFS 8427. 
Tabela 3.8: Características técnicas do módulo EFS 8427.

\begin{tabular}{|c|c|}
\hline \multicolumn{2}{|c|}{ CONFIGURAÇÕES } \\
\hline Gerador interno & 1 a $250 \mathrm{~Hz}$ (2 pulsos de tamanho ajustáveis) \\
\hline $\begin{array}{l}\text { Tensão de alimentação interna da bateria } \\
\text { (Vbat) }\end{array}$ & Programável de 6 a $50 \mathrm{~V}$ \\
\hline $\begin{array}{l}\text { Simulação do capacitor de alta voltagem } \\
\text { pull-in }\end{array}$ & Programável de 5 a $20 \mu \mathrm{F}$ \\
\hline Fase de alta voltagem pull-in & Programável de Vbat a $150 \mathrm{~V}$ \\
\hline Tensão de descarga Zener & Programável de -1 a $-150 \mathrm{~V}$ \\
\hline $\begin{array}{l}\text { Procura da voltagem de abertura do } \\
\text { injetor }\end{array}$ & Programável de Vbat a $-5 \mathrm{~V}$ \\
\hline \multicolumn{2}{|l|}{ Resolução de ajuste de voltagem } \\
\hline Frequência de acionamento & $\begin{array}{l}250 \mathrm{~Hz} \text { máximo (limitado pela } \mathrm{P} \text { do injetor < } \\
100 \mathrm{Wrms} \text { ) }\end{array}$ \\
\hline Duração entre duas unidades de injeção & Limitado pela corrente de retorno $<100 \mathrm{~mA}$ \\
\hline Limiares de corte de corrente & 1 a $30 \mathrm{~A}$ \\
\hline Histerese mínima de corrente & $0.1 \mathrm{~A}$ (frequência de corte $<100 \mathrm{~mA}$ ) \\
\hline Resolução dos ajustes de corrente & $0.1 \mathrm{~A}$ \\
\hline Resolução do tempo de atraso & $1 \mu \mathrm{s}$ \\
\hline \multicolumn{2}{|l|}{ MONITORAMENTO } \\
\hline Sinal lógico EOT & TTL \\
\hline Sinal do comando de injeção COMINJ & TTL \\
\hline Corrente no injetor & $\pm 10 \mathrm{~V}$ para $\pm 30 \mathrm{~A}$ \\
\hline Voltagem no injetor & $\pm 10 \mathrm{~V}$ para $\pm 200 \mathrm{~V}$ \\
\hline Cursores analógicos & $0-7,5 \mathrm{~V}(500 \mathrm{mV} / \mathrm{LSB})$ \\
\hline \multicolumn{2}{|l|}{ SINAIS DE COMANDO } \\
\hline $\begin{array}{l}\text { entrada BNC para sinal de controle } \\
\text { externo }\end{array}$ & TTL \\
\hline Entradas e saídas opto-isoladas & Compatível TTL 5 V no Mini conector 10 pinos \\
\hline Conexão RS485 opto-isolada & Mini conector 4-pinos \\
\hline Conexão RS232 & Macho 9 pinos DB \\
\hline \multicolumn{2}{|l|}{ REQUERIMENTOS E DIMENSÕES } \\
\hline Voltagem de alimentação & 90 a $240 \mathrm{Vac} / 50$ a $60 \mathrm{~Hz}$ \\
\hline Potência (máxima) & $180 \mathrm{~W}$ \\
\hline Dimensões & $440 \mathrm{~mm} \times 360 \mathrm{~mm} \times 88 \mathrm{~mm}$ \\
\hline Peso & $6,1 \mathrm{~kg}$ \\
\hline
\end{tabular}

\subsubsection{Gerador de funções arbitrárias}

O gerador de funções arbitrárias tem como principal função enviar a onda relativa ao pulso de injeção ao módulo EFS Ipod Coil, descrito acima. Este pulso é enviado em forma de onda quadrada, conforme ilustrado na Figura 3.22. 


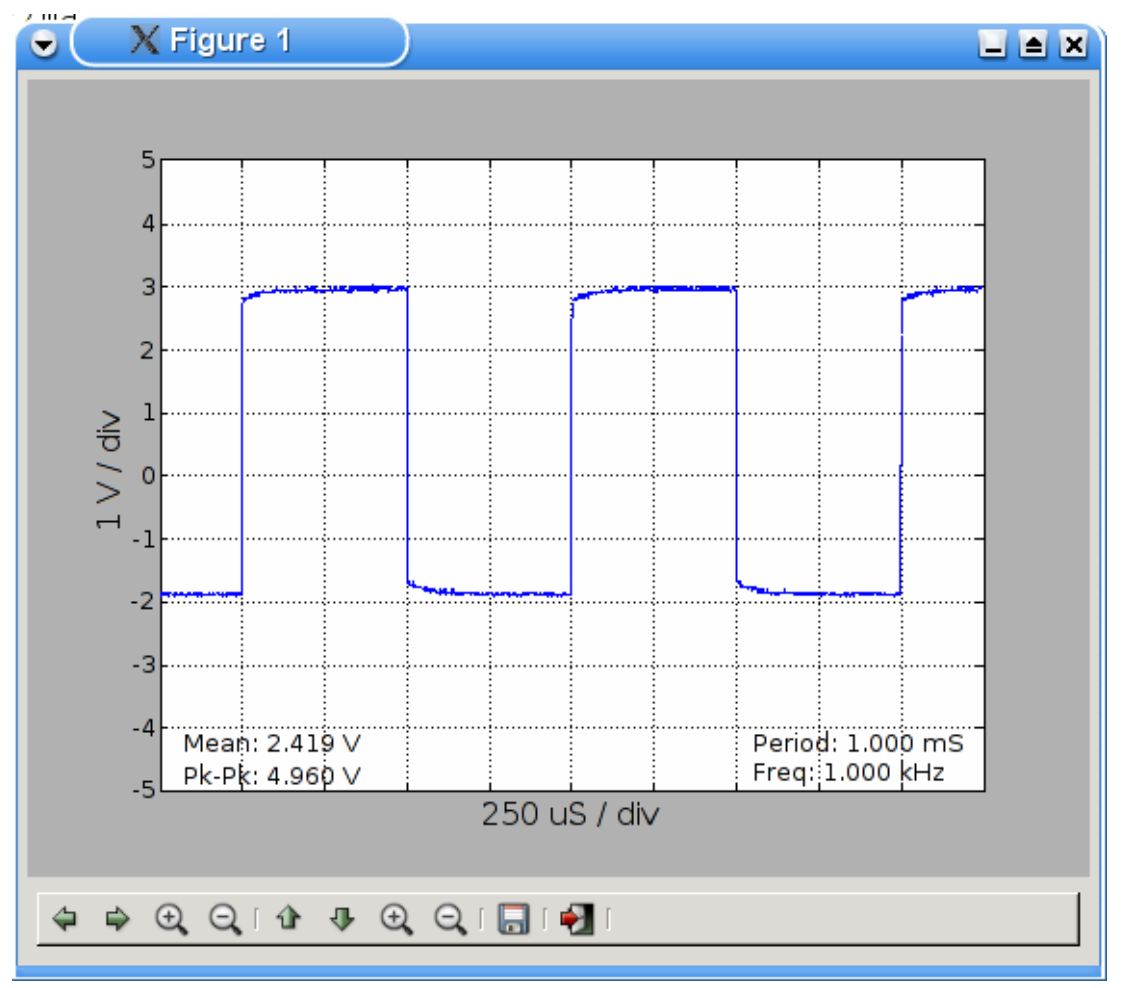

Figura 3.22: Imagem das ondas quadradas enviadas ao módulo EFS.

Desta forma, as principais informações enviadas através do gerador são: tempo de injeção, intervalo entre os pulsos e o número de pulsos. Sendo assim, o tempo de duração da onda gerada necessita ser a soma dos tempos relativos ao "peak" e ao "hold" enviados ao injetor através do módulo EFS Ipod Coil. Como os sinais de injeção são enviados do gerador de funções arbitrárias ao módulo $E F S$, o gerador acaba funcionando como um trigger das injeções, acionando, assim, o módulo EFS externamente.

O gerador de funções aleatórias utilizado na bancada de testes de vazão foi da marca Tektronix, modelo TDS 2012 B, ilustrado na Figura 3.23, a seguir. A tabela seguinte apresenta as características técnicas do gerador de funções Tektronix TDS 2012 B. 


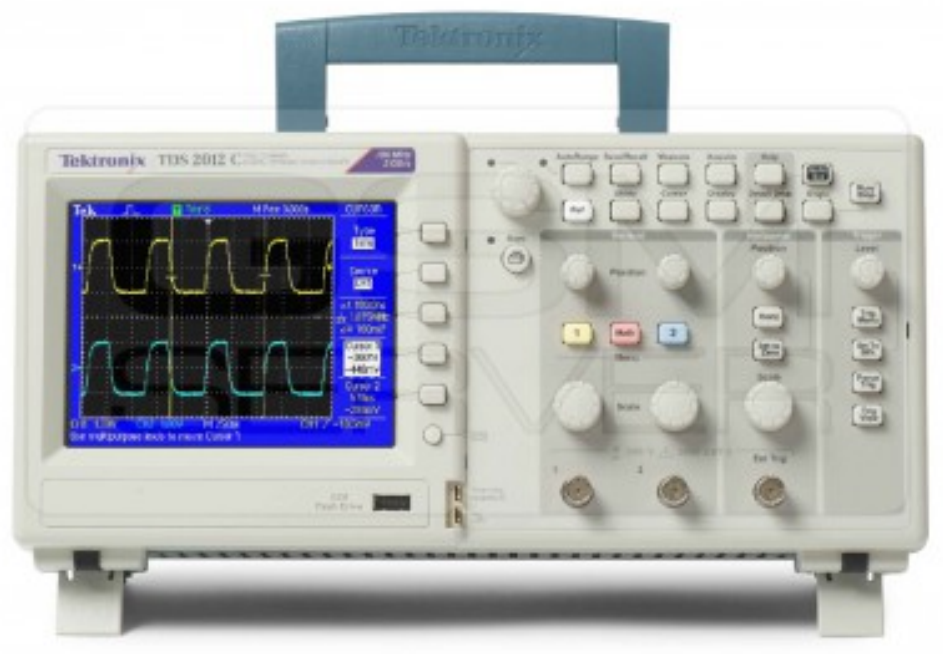

Figura 3.23: Imagem do gerador de funções arbitrárias utilizado durante os ensaios.

Tabela 3.9: Características técnicas do gerador de funções arbitrárias Tektronix TDS 2012.

\begin{tabular}{|l|l|}
\hline Tela (1/4 VGA LCD) & Colorida \\
\hline Largura de banda & $100 \mathrm{MHZ}$ \\
\hline Canais & 2 \\
\hline Entrada de Trigger externa & Sim \\
\hline $\begin{array}{l}\text { Taxa de amostragem por } \\
\text { canal }\end{array}$ & $1,0 \mathrm{GS} / \mathrm{s}$ \\
\hline Tamanho da gravação & $2,5 \mathrm{~K}$ \\
\hline Resolução Vertical & 8 -bits \\
\hline Sensibilidade Vertical & $2 \mathrm{mV}$ a $5 \mathrm{~V} /$ div \\
\hline Precisão DC Vertical & $\pm 3 \%$ \\
\hline Alcance de posição & $2 \mathrm{mV}$ a $200 \mathrm{mV} / \mathrm{div} \pm 2 \mathrm{~V} ;$ \\
$>200 \mathrm{mV}$ a $5 \mathrm{~V} / \mathrm{div} \pm 50 \mathrm{~V}$ \\
\hline Limite BW & $20 \mathrm{MHZ}$ \\
\hline Impedância de entrada & $1 \mathrm{M} \Omega$ em paralelo com $20 \mathrm{pF}$ \\
\hline Alcance de tempo de base & $5 \mathrm{~ns}$ a $5 \mathrm{~s} /$ div \\
\hline Precisão de tempo de base & $50 \mathrm{ppm}$ \\
\hline
\end{tabular}




\subsection{Análise Química dos Depósitos}

\subsubsection{Microscópio Eletrônico de Varredura (MEV) com EDX acoplado}

O microscópio eletrônico de varredura, mostrado na Figura 3.24 a seguir, é um equipamento capaz de produzir imagens de alta ampliação (até 300.000×) sem perda significativa na resolução. As imagens fornecidas pelo MEV possuem caráter virtual, pois o que é visualizado no monitor do aparelho é a transcodificação da energia emitida pelos elétrons.

Seu princípio de funcionamento consiste na emissão de feixes de elétrons por um filamento capilar de tungstênio (eletrodo negativo), mediante a aplicação de uma diferença de potencial que pode variar de 0,5 a $30 \mathrm{KV}$. Essa variação de voltagem ocasiona uma variação da aceleração dos elétrons, e também provoca o aquecimento do filamento. A parte positiva em relação ao filamento do microscópio (eletrodo positivo) atrai fortemente os elétrons gerados, resultando numa aceleração em direção ao eletrodo positivo. A correção do percurso dos feixes é realizada pelas lentes condensadoras que alinham os feixes em direção à abertura da objetiva. A objetiva, portanto, ajusta o foco dos feixes de elétrons antes dos mesmos atingirem a amostra analisada.

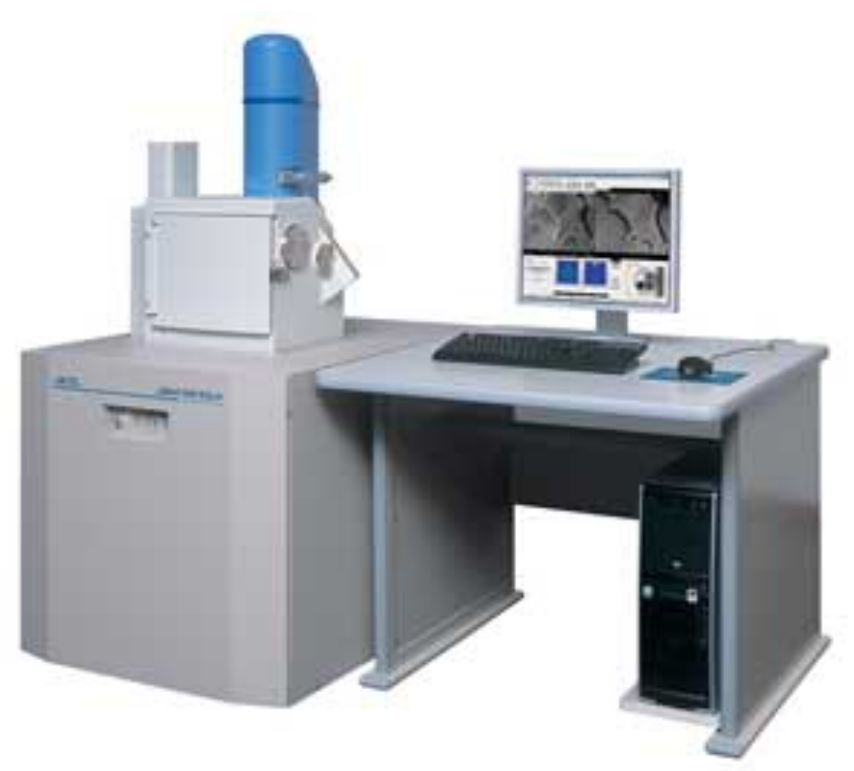

Figura 3.24: Microscópio eletrônico de varredura com EDX acoplado. 
O EDX (Energy dispersive X-Ray) é um acessório essencial no estudo de caracterização microscópica de materiais. Quando o feixe de elétrons incide sobre um mineral, os elétrons mais externos dos átomos e íons constituintes são excitados, mudando de níveis energéticos. Ao retornarem para sua posição inicial, liberam a energia adquirida a qual é emitida em comprimento de onda no espectro de raios-x. Um detector instalado na câmara de vácuo do MEV mede a energia associada a esse elétron. Como os elétrons de um determinado átomo possuem energias distintas, é possível, no ponto de incidência do feixe, determinar quais os elementos químicos presentes naquele local e assim identificar em instantes a composição da região que está sendo analisada. O diâmetro reduzido do feixe permite a determinação da composição de tamanhos muito reduzidos $(<5 \mu \mathrm{m})$, permitindo uma análise quase que pontual muito importante na compreensão dos depósitos.

Portanto, para o presente trabalho, o uso conjunto do EDX e do MEV foi de grande importância, uma vez que o MEV proporciona nítidas imagens, o EDX permite sua imediata identificação.

Além da identificação mineral das camadas de depósitos, o equipamento ainda permitiu o mapeamento da distribuição de elementos químicos por minerais, gerando mapas composicionais dos elementos desejados.

\subsection{Análise química de combustíveis}

As análises químicas realizadas para caracterizar os combustíveis utilizados durante o trabalho foram feitas com diferentes equipamentos. A seguir estes aparelhos serão detalhados brevemente.

Os teores de goma lavada e não lavada das gasolinas ensaiadas foram medidos através de um GUM Tester 915 HGT HERZOG, por meio de um processo de medição de resíduos evaporados. Este aparelho tem capacidade de medir três amostras de $100 \mathrm{ml}$ simultaneamente.

Já a quantidade de enxofre total contido no combustível foi medida através de um analisador de nitrogênio e enxofre total Antek 9000, com sensibilidade para valores baixos (ppm) até níveis percentuais. 
As concentrações de olefinas, saturados, aromáticos e benzenos foram todos quantificados utilizando um analisador IROX 2000 da marca Grabner. Este equipamento, ao invés de utilizar poucas linhas de filtro, faz a medição de um espectro completo de absorção, o que fornece informação completa das substâncias presentes na gasolina, elimina variações da linha de base e minimiza interferências.

Para realizar a cromatografia de íons (ânions) e ICP-MS (cátions) foi utilizado um cromatógrafo de íons Dionex modelo ICS-90 com amostrador automático AS-40. Para a dosagem de ânions foi empregada uma coluna analítica AS-9HC, pré-coluna AG-9HC e uma supressora química AMMS III, todos de quatro milímetros. O eluente utilizado foi Carbonato de Sódio $9 \mathrm{mmol} / \mathrm{L}$ e a solução regenerante da supressora foi ácido sulfúrico $25 \mathrm{mmol} / \mathrm{L}$. Os cátions foram determinados utilizando uma coluna analítica CS-12A, pré-coluna CG-12 e uma supressora eletrolítica CSRS 3000, todos também quatro milímetros. O eluente utilizado foi ácido sulfúrico $10 \mathrm{mmol} / \mathrm{L}$. 


\section{4 \\ Metodologias}

Neste capítulo serão detalhadas as metodologias experimentais utilizadas durante os ensaios realizados a fim de compreender a formação de depósitos nos bicos injetores do motor Peugeot EP6 CDTM.

\subsection{Ensaios no dinamômetro de chassis}

Os veículos utilizados durante o projeto foram testados em um dinamômetro de chassis, automatizado com um robô piloto, como mostrado na Figura 4.1 a seguir.

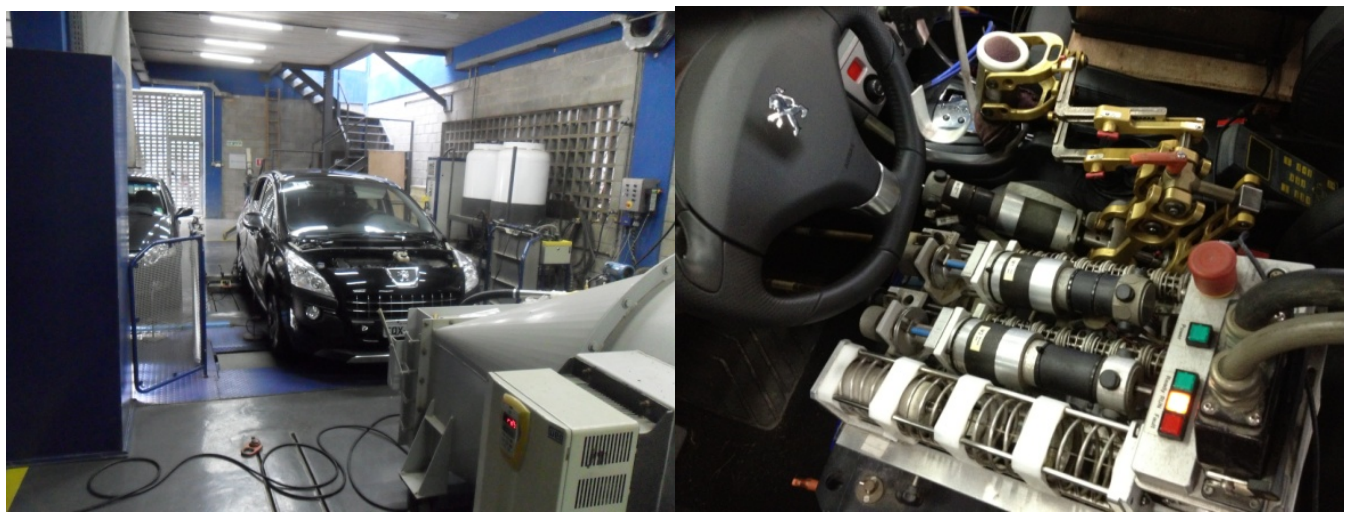

(a)

(b)

Figura 4.1: (a) Foto do ensaio no dinamômetro de chassis; (b) detalhe do robô piloto durante um dos testes realizados.

Os testes foram conduzidos com o auxílio de um sistema de abastecimento de gasolina composto por dois tanques suspensos com capacidade de $1000 \mathrm{~L}$, uma bomba de combustível e um módulo de abastecimento automático de combustível 
AVL. Através do sensor de nível que se encontra dentro do tanque do carro, um sinal é enviado ao sistema de abastecimento, e a cada vez que o sensor acusa que o combustível no tanque chegou na metade, o sistema de abastecimento automático deposita mais cinco litros de gasolina no tanque. Desta maneira, os testes podem ser conduzidos continuamente.

A metodologia adotada para os ensaios seguiu os requerimentos estabelecidos na norma ABNT 14008-2007 [9] para veículos leves. O ciclo testado no dinamômetro de chassis segue uma curva de velocidade por tempo, que foi programada segundo o ciclo AMA, ajustado propriamente ao veículo testado. A troca de marchas é configurada de acordo com o veículo em testes.

Os testes foram realizados utilizando combustíveis com diferentes formulações. O principal componente químico alterado era a concentração de sulfato, ou enxofre contido no combustível. Para cada gasolina utilizada, o ensaio era conduzido até que o valor da variável de correção do tempo de injeção, FRA, atingisse seu valor limite de 1,3, ou até o veículo chegar na marca de 10.000 quilômetros rodados.

Visando começar os testes sempre com as mesmas condições iniciais, antes de cada ensaio eram trocados os bicos injetores, filtros de ar, óleo e combustível.

Os ensaios foram monitorados através dos softwares INCA(ETAS), responsável pela leitura das variáveis contidas na UCE e Scandiag, responsável pelo diagnóstico da UCE.

\subsection{Road Test}

Alguns testes foram realizados a fim de compreender a origem dos depósitos e, em seguida, conferir se os métodos de limpeza destes depósitos, encontrados no mercado, se mostravam efetivos. Para isso, foram testados diversos aditivos durante os testes de rua, chamados ao longo do trabalho de Road Test. Os aditivos utilizados durante o teste foram elaborados para motores PFI, uma vez que não foram encontrados aditivos específicos para remoção de depósitos em motores com a tecnologia GDI. 
Foram utilizados dois métodos de aplicação de aditivo, ao longo dos ensaios. $\mathrm{O}$ volume e a frequência destes aditivos eram determinados por seus fabricantes.

Os métodos utilizados foram os seguintes:

- Keep Clean: a fim de evitar que os depósitos se formassem, os testes realizados utilizando este método tinham adição de aditivos no tanque a cada 2.000 quilômetros, em menores volumes.

- Clean Up: este segundo método tinha como objetivo a tentativa de remoção de depósitos que já haviam sido formados. Para isso, os volumes de aditivos adicionados ao tanque eram maiores, e o aditivo era misturado ao tanque a cada 5.000 quilômetros rodados.

Durante estes testes, os dados provenientes da UCE eram recolhidos a cada 1.000 quilômetros, para análises futuras.

Para cada aditivo testado, um grupo de testes contendo cinco veículos idênticos era utilizado. Os grupos de teste eram divididos da seguinte forma:

\author{
Veículo 1 - Fabricante 1 - Método "Keep Clean" \\ Veículo 2 - Fabricante 1 - Método "Keep Clean" \\ Veículo 3 - Fabricante 1 - Método "Clean Up" \\ Veículo 4 - Fabricante 1 - Método "Clean Up" \\ Veículo 5 - Fabricante 1 - Veículo de referência (sem aditivos)
}

Todos os veículos de um grupo rodavam juntos em fila e eram abastecidos simultaneamente.

Inicialmente, três fabricantes foram testados em três grupos de testes. É importante ressaltar que os injetores eram trocados no início de cada teste. Para obter uma maior confiança sobre os dados recolhidos, dois veículos foram utilizados para cada um dos métodos de aplicação de aditivo, e um veículo era utilizado como referência, como mostrado acima.

\title{
4.3. Teste de vazão dos injetores
}


A metodologia utilizada nos testes de vazão dos bicos injetores baseou-se em valores de tempo e pressão de injeção gravados da central eletrônica durante uma rodagem de um dos veículos de teste, através do software INCA.

Para o tempo de injeção, observou-se que o tempo mínimo enviado como comando pela UCE era de 2,5 ms, e o máximo era de 7,5 ms. Já a pressão de injeção, variava de valores próximos à 5 bar, quando o motor operava em condições de marcha lenta, até valores próximos à 120 bar, em regimes mais severos de operação. Para determinação da pressão utilizada nos testes de vazão, foi feita uma média das pressões registradas na rodagem do veículo e a pressão estipulada como referência foi de 111 bar.

Foi realizada a caracterização de um bico injetor novo, utilizando a pressão de referência, para os tempos de injeção variando de 2,5 a $6,5 \mathrm{~ms}$, com incremento de $1 \mathrm{~ms}$. Este mesmo processo era repetido para os injetores depositados, retirados do motor após os testes no dinamômetro de chassis.

Desta forma, uma análise quantitativa da perda de vazão após os testes se faz possível, através da comparação dos resultados obtidos nos bicos utilizados no carro com o bico novo de referência.

A determinação da vazão é feita através da massa de combustível injetada por pulso de injeção. Esta medição é feita através da pesagem de uma pipeta, com capacidade de $100 \mathrm{ml}$, antes e depois de mil pulsos de injeção. Cada medição é repetida três vezes, e a partir dessas medidas é feita uma média, a fim de minimizar as incertezas do processo. Desta forma, repetindo este procedimento para os tempos de injeção escolhidos é possível que se obtenha uma curva de injeção e, assim, pode-se extrapolar a vazão para outros valores de tempo injeção, caso necessário.

\subsection{Teste de vazão dos injetores com temperaturas elevadas}

Para os testes que necessitavam de alta temperatura no corpo do bico injetor, foi elaborada uma peça de alumínio, com espaço para três resistências do tipo bastão, que é acoplada a parte inferior do injetor, conforme mostrado no esquema da Figura 4.2. 


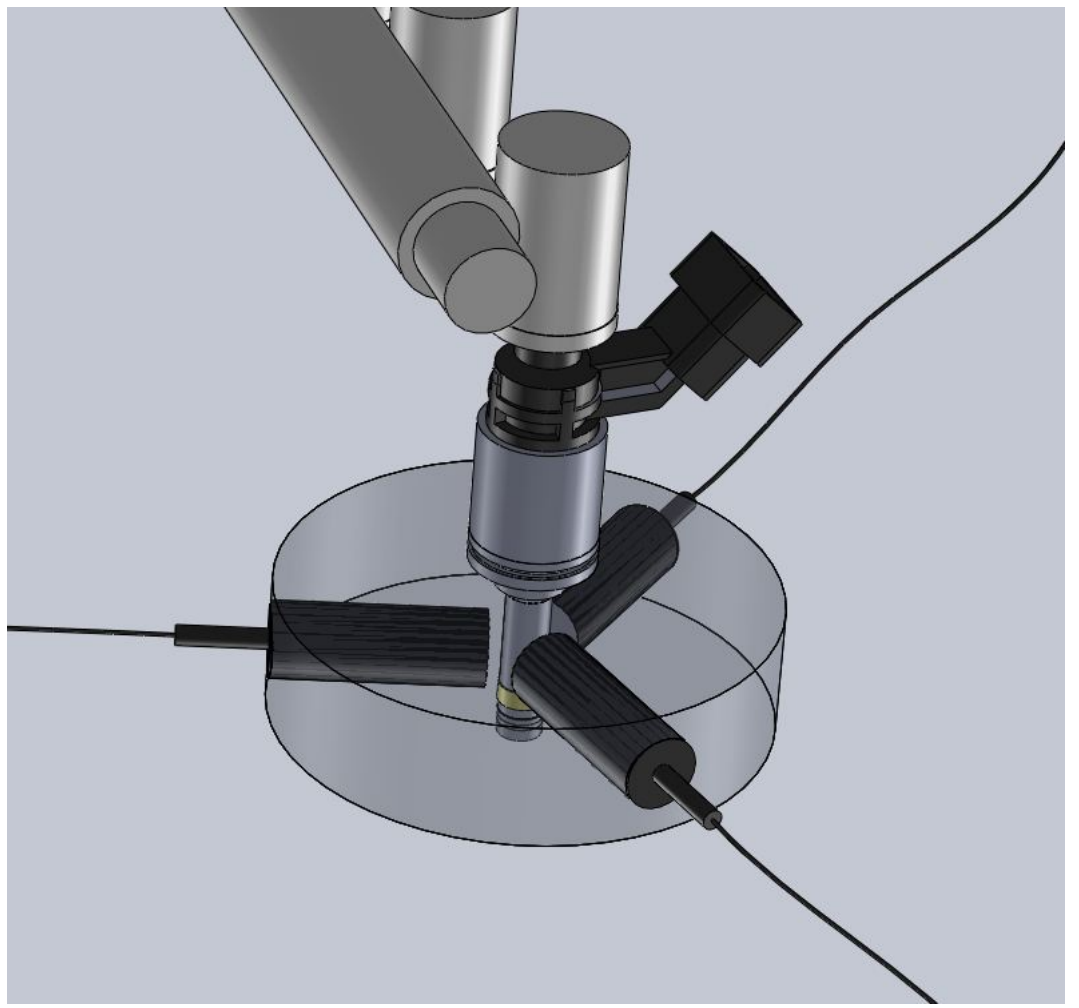

Figura 4.2: Imagem esquemática do teste de vazão com temperaturas elevadas.

Os resistores utilizados tinham uma potência nominal de $60 \mathrm{~W}$, cada, e quando ligados submetiam a peça a uma temperatura de aproximadamente $300^{\circ} \mathrm{C}$.

Para o controle da temperatura do componente, um termopar do tipo $\mathrm{K}$ foi instalado na peça de alumínio, próximo ao injetor (Figura 4.3). Este sensor foi conectado a um regulador de temperatura, que por sua vez, foi conectado a um relé de estado sólido. Sendo assim, quando a temperatura alcançava o valor programado no regulador, o relé de estado sólido desligava a voltagem de alimentação dos resistores e, de maneira análoga, ligava a tensão quando a temperatura ficava abaixo da temperatura estabelecida. O limite estabelecido no controle foi de $\pm 1^{\circ} \mathrm{C}$, porém devido ao tempo de inércia térmica, a incerteza na medição de temperatura ficou em $\pm 2^{\circ} \mathrm{C}$. 


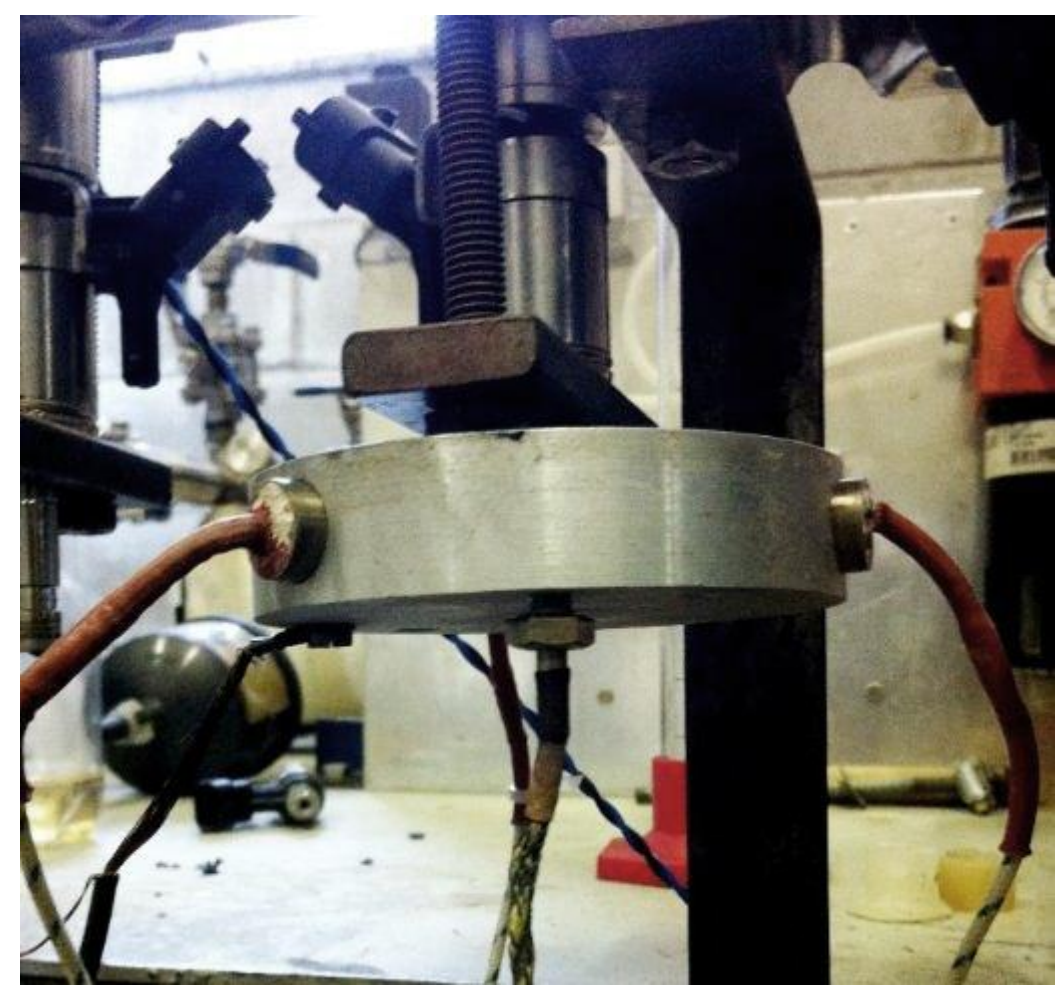

Figura 4.3: Detalhe da instalação do termopar na peça de alumínio.

Com o mesmo aparato experimental descrito no item 3.4.4, depois de atingir a temperatura estipulada no controlador, o bico injetor em teste era submetido a um ciclo de pulsos de injeção. Este ciclo foi programado para simular uma rodagem de 10.000 quilômetros. Para isso, foram determinados pressão e tempo de injeção, e uma velocidade simulada de $80 \mathrm{~km} / \mathrm{h}$, a fim de determinar o espaço entre cada pulso.

Medidas de vazão foram realizadas periodicamente com o intuito de verificar se haveria formação de depósitos durante o ensaio, seguindo a metodologia descrita no item anterior, 4.3.

\subsection{Caracterização química dos depósitos}

A análise dos depósitos teve por objetivo caracterizar os produtos formados na superfície inferior dos bicos injetores após os ensaios realizados em dinamômetro de chassis ou na rua. As amostras foram então analisadas diretamente no microscópio eletrônico de varredura (MEV), utilizando recursos de microanálise por EDS (Energy 
Dispersive Spectroscopy) a fim de caracterizar os produtos encontrados. Para que as amostras fossem analisadas, os injetores eram cuidadosamente cortados transversalmente, para que sua extremidade coubesse no Microscópio Eletrônico. Algumas amostras foram, ainda, seccionadas longitudinalmente ao eixo do bico injetor com o objetivo de se observar a superfície interna na região do furo. $\mathrm{O}$ seccionamento das peças foi realizado utilizando uma máquina de corte ISOMET, de pequenas dimensões, sem a adição de líquidos de refrigeração para não ocorrer contaminação do depósito e em baixa rotação para evitar o aquecimento da peça. Essas regiões foram então analisadas no MEV.

Para fins de registro algumas amostras foram fotografadas utilizando uma lupa estereoscópica.

\subsection{Caracterização química dos combustíveis}

A fim de caracterizar os combustíveis utilizados nos testes do dinamômetro de chassis, e no teste de vazão, foram analisadas amostras desses combustíveis para verificar seu atendimento ao regulamento técnico ANP N07 de 2011 [7]. Foram utilizadas as normas ASTM/ABNT recomendadas pela ANP.

Algumas das gasolinas testadas foram adquiridas em centros de distribuição. Já as gasolinas que necessitavam de uma composição especial quanto ao teor de enxofre foram entregues pela Petrobras em tambores de 200L.

A Tabela 4.1 apresenta as normas utilizadas para cada uma das análises realizadas.

Tabela 4.1: Principais parâmetros analisados e os métodos de ensaio empregados na caracterização dos combustíveis.

\begin{tabular}{|l|l|}
\hline \multicolumn{1}{|c|}{ CARACTERÍSTICA } & \multicolumn{1}{c|}{ MÉTODO DE ENSAIO } \\
\hline Goma Lavada, mg/100ml & ASTM D381 \\
\hline Enxofre Total,mg/kg & ASTM D5453 \\
\hline Teor Alcoólico, \%V/V & ABNT NBR13992 \\
\hline Água Karl Fisher, mg/kg & ASTM D6304 \\
\hline
\end{tabular}




\begin{tabular}{|l|l|}
\hline MON & INFRA-VERM GS 1000 PLUS \\
\hline RON & INFRA-VERM GS 1000 PLUS \\
\hline IAD & INFRA-VERM GS 1000 PLUS \\
\hline Olefina, \% & INFRA-VERM GS 1000 PLUS \\
\hline Saturado, \% & INFRA-VERM GS 1000 PLUS \\
\hline Aromático, \% & INFRA-VERM GS 1000 PLUS \\
\hline Benzeno, \% & INFRA-VERM GS 1000 PLUS \\
\hline
\end{tabular}

Foram ainda realizadas análises a fim de quantificar a presença de cátions $\left(\mathrm{Na}^{+}, \mathrm{K}^{+}, \mathrm{Ca}^{+2}, \mathrm{Mg}^{+2}\right)$ e ânions $\left(\mathrm{F}^{-}, \mathrm{Cl}^{-}, \mathrm{Br}^{-}, \mathrm{NO}_{3}^{-}, \mathrm{HPO}^{-2}\right.$ e $\left.\mathrm{SO}^{-2}\right)$ em amostras de gasolina e etanol. Uma vez que a legislação brasileira não exige através de regulamentação técnica a dosagem desses íons não existe até o momento nenhum laboratório que realize esses ensaios de forma rotineira. Foi então desenvolvida uma metodologia com base na norma ASTM D7328 "Standard Test Method for Determination of Total and Potencial Inorganic Sulfate and Total Inorganic Chloride in Fuel Ethanol by Ion Chromatography Using Aqueous Sample Injection".

Essa norma embora seja aplicada para o etanol combustível, pode ser adaptada ao combustível nacional uma vez que a gasolina brasileira utiliza etanol em sua formação. De forma simplificada o procedimento baseia-se na extração dos íons, utilizando água, com posterior destilação da mistura e solubilização com água. Na etapa seguinte a amostra é analisada um cromatógrafo de íons para identificação e quantificação dos cátions e ânions presentes no combustível em testes.

Vale lembrar que os sulfurados presentes no petróleo podem estar presentes nas formas de ácido sulfídrico, dissulfeto de carbono, sulfeto de carbonila, mercaptans, sulfetos, dissulfetos e polissulfetos. A extração do etanol da gasolina utilizando água pode também retirar os compostos mais polares tais como sulfoxido, sulfodioxidos ou sulfatos. 


\section{5 \\ Resultados e discussões}

No presente capítulo serão apresentadas as análises e discussões dos resultados obtidos ao longo dos ensaios realizados no dinamômetro de chassis, Road Tests e nos testes de vazão dos bicos injetores.

Serão apresentadas, também, as análises químicas realizadas nas gasolinas formuladas para os ensaios, assim como a caracterização dos depósitos formados ao longo dos testes.

\subsection{Road Test preliminar}

O primeiro ensaio realizado no presente trabalho teve como principal objetivo verificar se as gasolinas formuladas levariam o veículo em testes a ter seus injetores depositados. Para isso, o veículo 3008 foi submetido a um Road Test, utilizando a gasolina identificada por $C O$ (Tabela 5.1), e o valor da adaptação do tempo de injeção (FRA) foi monitorado, a cada $1.000 \mathrm{~km}$ rodados. Desta maneira, se essa variável de adaptação atingisse seu valor limite, seria considerado que este veículo teve seus bicos injetores depositados.

O gráfico a seguir (Figura 5.1) apresenta o resultado de um dos primeiros testes de acúmulo de quilometragem feito na rua. Pode-se notar que, com aproximadamente $8.000 \mathrm{~km}$, a variável FRA já apresenta seu valor limite, próximo a 1,3 . 


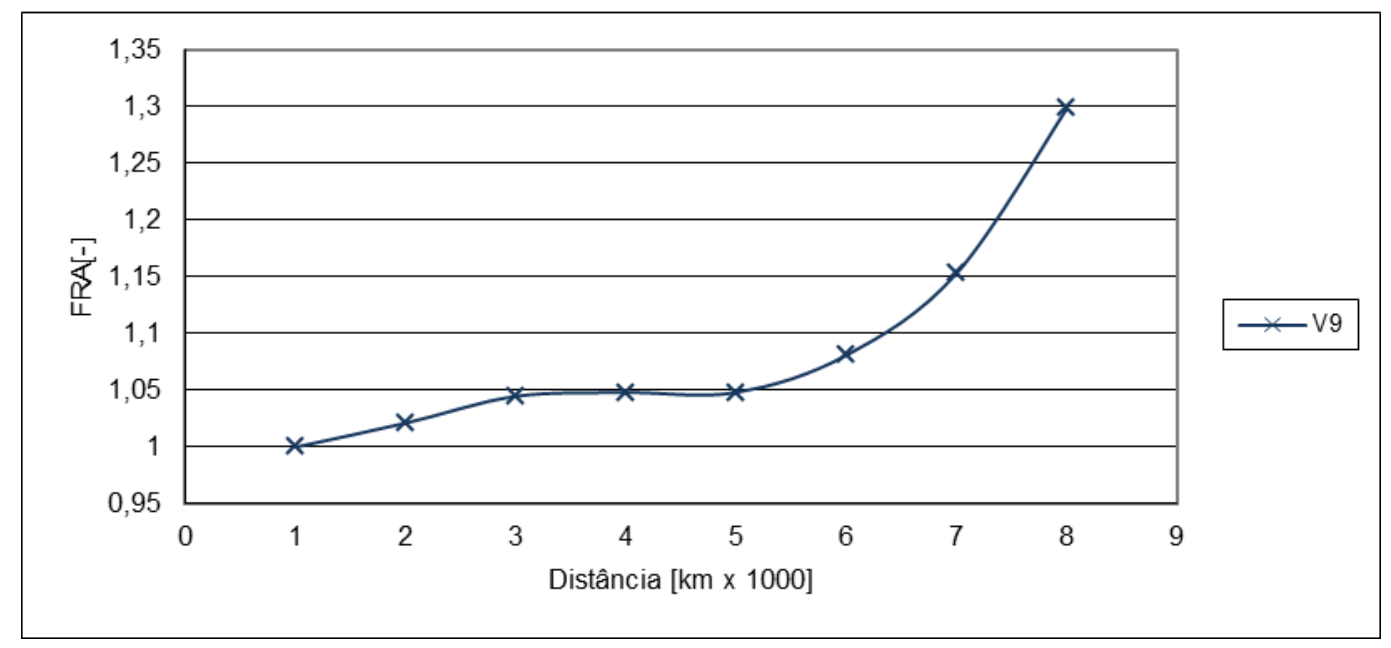

Figura 5.1: Acompanhamento FRA - Primeiro Road Test preliminar, gasolina $C 0$

Posteriormente, o veículo teve seus bicos injetores trocados, assim como os filtros de óleo, gasolina e ar, e outro ensaio foi iniciado. Novamente foi possível se perceber que, para uma quilometragem relativamente baixa, o veículo atingiu o valor de $30 \%$ de adaptação de combustível, conforme mostrado na Figura 5.2 a seguir.

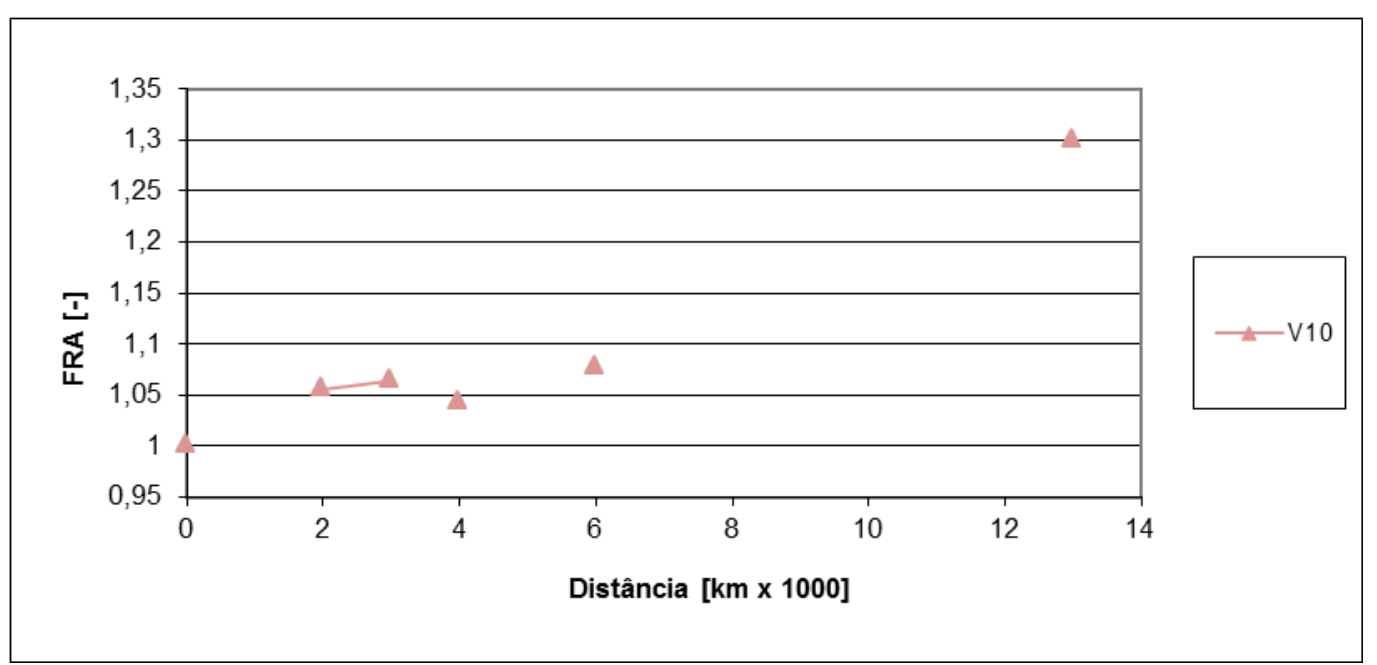

Figura 5.2: Acompanhamento FRA - Segundo Road Test preliminar, gasolina $C 0$

Tendo em vista que os dois testes realizados tiveram os valores limite da variável de adaptação do tempo de injeção atingidos, foi possível concluir que os 
bicos injetores estavam sofrendo deposição e, consequentemente, tendo sua vazão alterada, para a gasolina formulada.

A gasolina $\mathrm{C} 0$, utilizada durante estes ensaios preliminares, foi encomendada de acordo com as especificações da norma técnica da ANP (Agência Nacional de Petróleo, Gás Natural e Biocombustíveis), n 7, de 2011. Optou-se por dosar o combustível com um teor de enxofre que respeitasse a regulação brasileira, mas fosse maior que os encontrados em países europeus e nos Estados Unidos, onde esta tecnologia de motores já é mas difundida.

Em paralelo com os ensaios de Road Test, foi realizada uma caracterização química do combustível, apresentada na Tabela 5.1 abaixo.

Tabela 5.1: Caracterização da gasolina $C 0$

\begin{tabular}{|c|c|}
\hline & Gasolina CO \\
\hline Goma Lavada (mg/100 mL) & 0,9 \\
\hline Enxofre Total & 384 \\
\hline Teor Alcoólico \% V/V & 26 \\
\hline Água (mg/kg) & 5297 \\
\hline Olefina (\%) & 12,6 \\
\hline Saturado (\%) & 46,5 \\
\hline Aromático (\%) & 15,3 \\
\hline Benzeno (\%) & 0,4 \\
\hline IAD & 87,8 \\
\hline
\end{tabular}

Para dar continuidade a investigação, uma análise química foi conduzida para saber quais os principais compostos presentes nos depósitos formados nos bicos injetores durantes os Road Tests preliminares. Os resultados encontrados estão apresentados no item 5.1.1, a seguir.

\subsubsection{Caracterização dos depósitos formados em um injetor utilizado nos Road Tests preliminares}

As Figura 5.3 e 5.4 ilustram a aparência visual dos injetores de combustíveis relativos ao motor EP6 CDTm antes e depois dos testes serem realizados. A primeira delas (Figura 5.3) é uma imagem feita com uma câmera fotográfica 
convencional e lente macro, enquanto a segunda imagem (Figura 5.4) foi obtida através de um microscópio estereoscópico.

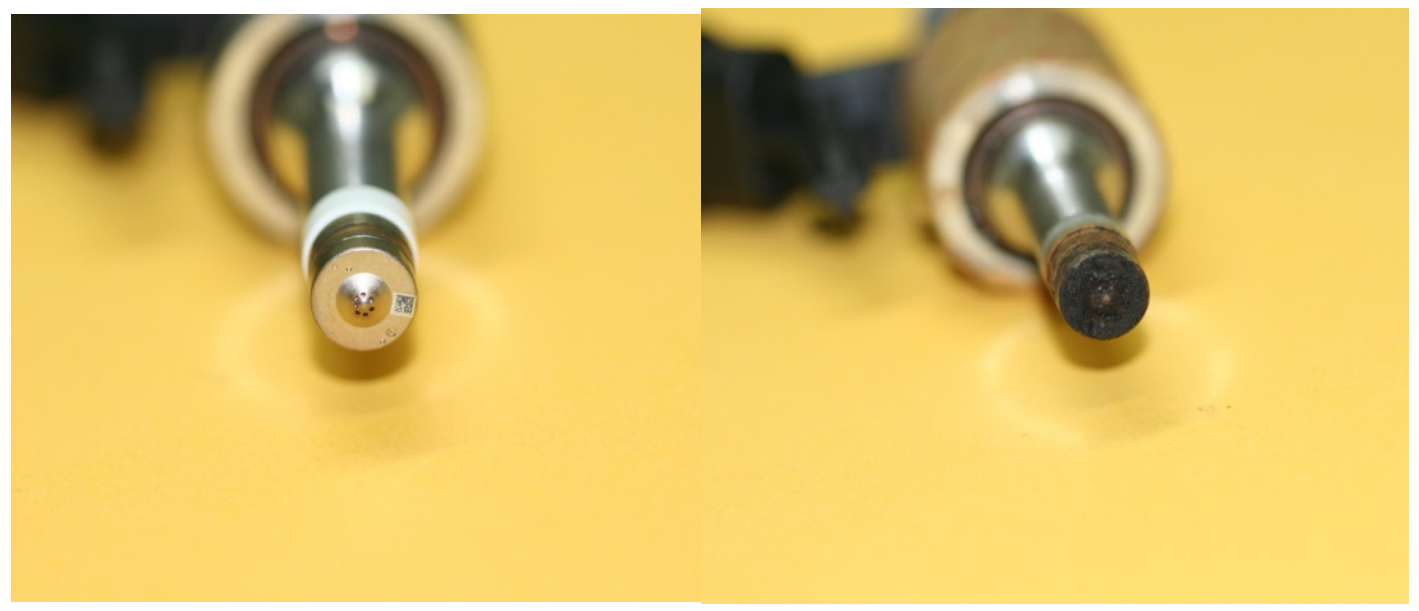

(a)

(b)

Figura 5.3: Visão frontal de um injetor: (a) injetor novo (antes dos testes) (b) injetor retirado do veículo após um teste.

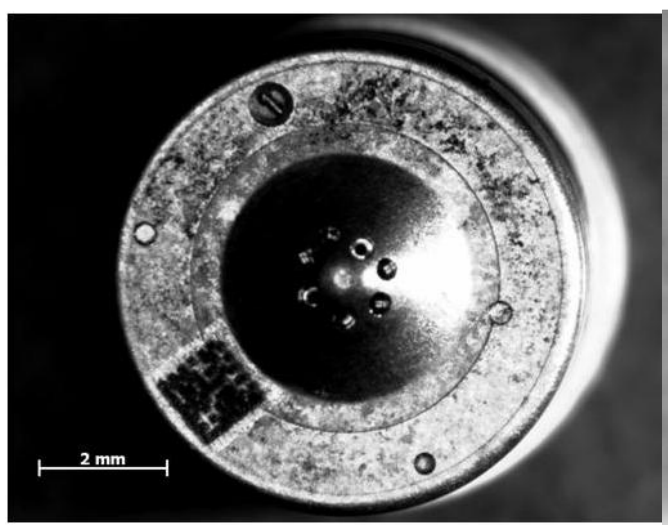

(a)

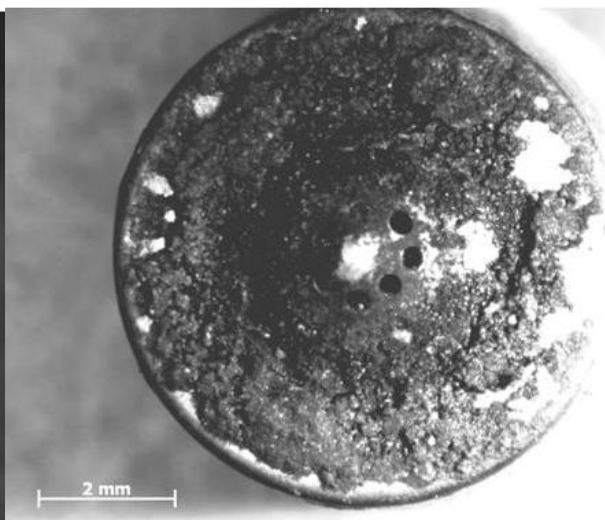

(b)

Figura 5.4: Visão frontal dos injetores mostrados na Figura 5.3 utilizando um microscópio estereoscópico.

As Figuras 5.5 a 5.9 mostram, de forma mais detalhada, a superfície externa do injetor depositada. Através da Figura 5.5, a seguir, é possível verificar camadas depositadas, tanto na superfície externa, quanto nas cavidades internas do injetor. 


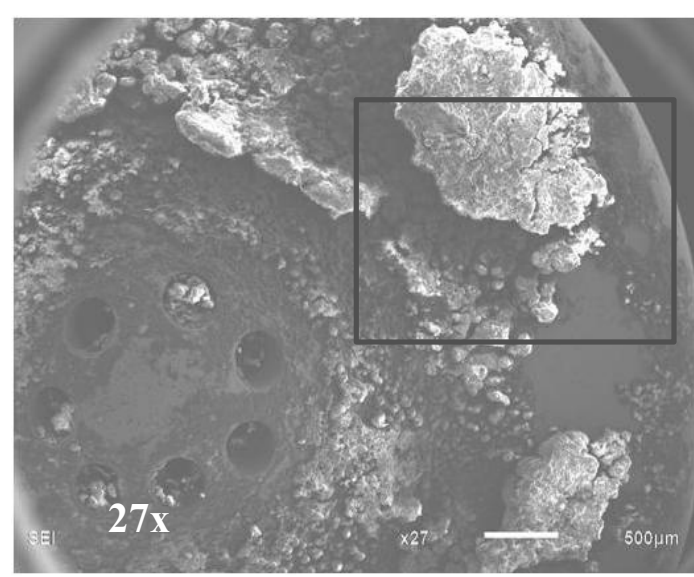

(a)

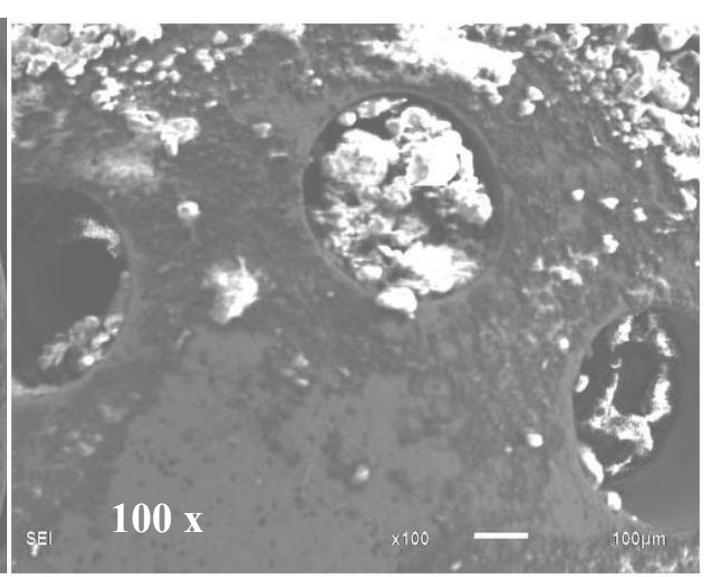

(b)

Figura 5.5: Imagem da superfície exterior do injetor, feita com o microscópio eletrônico de varredura.

A Figura 5.6 apresenta uma imagem ainda mais detalhada dos depósitos, assim como os pontos que tiveram suas concentrações analisadas.

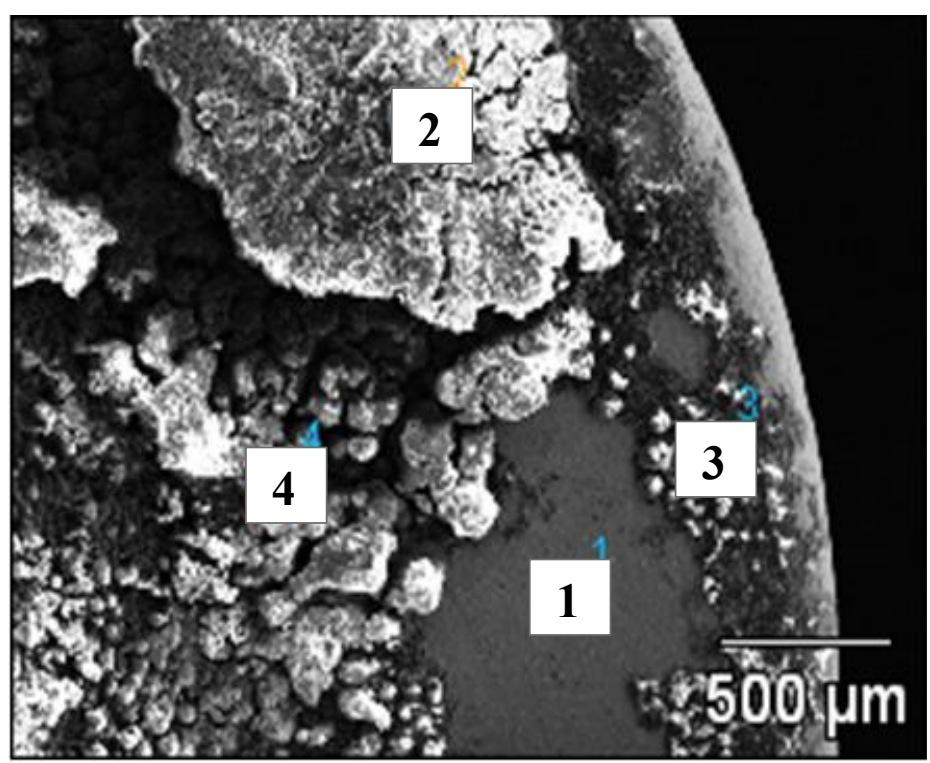

Figura 5.6: Detalhe da região em destaque na Figura 5.5 e dos pontos 1,2,3 e 4 escolhidos para análise (imagem realizada com o MEV).

Os gráficos na Figura 5.7, apresentam os espectros relativos aos pontos 1,2,3 e 4 analisados, indicados na Figura 5.6. 


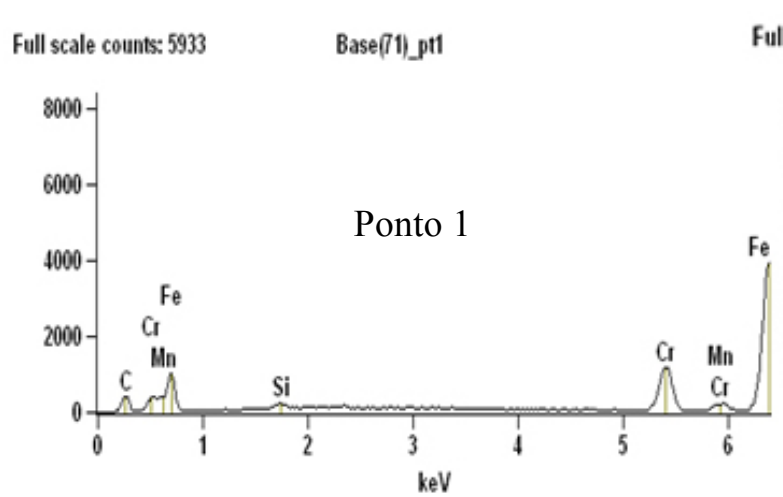

(a)

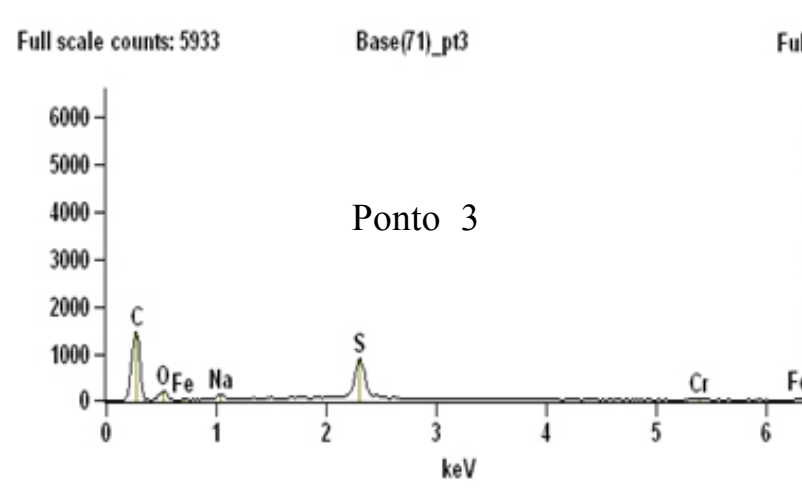

(c)
Full scale counts: $5933 \quad$ Base(11)_pt

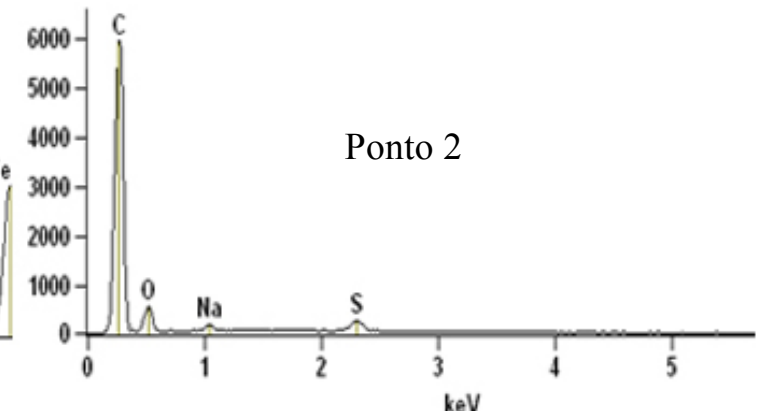

(b)

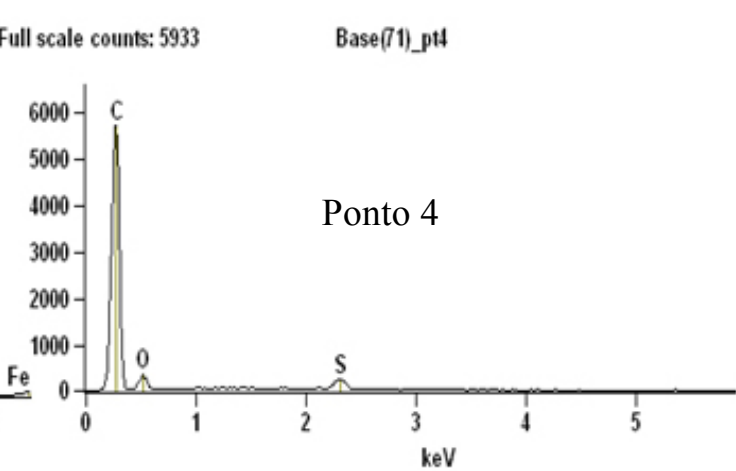

(d)

Figura 5.7: Análise dos pontos 1,2,3 e 4, mostrados na Figura 5.6, realizada por EDS, no microscópio eletrônico de varredura.

Os elementos predominantes nas análises químicas realizadas neste injetor foram: carbono $(\mathrm{C})$, oxigênio $(\mathrm{O})$ e enxofre $(\mathrm{S})$, sendo a liga da base metálica (relativa ao ponto 1 da Figura 5.6) composta predominantemente por ferro (Fe), cromo (Cr) e manganês (Mn), Figura 5.7 (a).

A Figura 5.8, a seguir, detalha a região indicada pelo ponto 3 da Figura 5.6. O espectro relativo ao ponto 1 da Figura 5.8 (a), mostrado na Figura 5.8 (b), demonstra a presença de composto ricos em enxofre e ferro. 


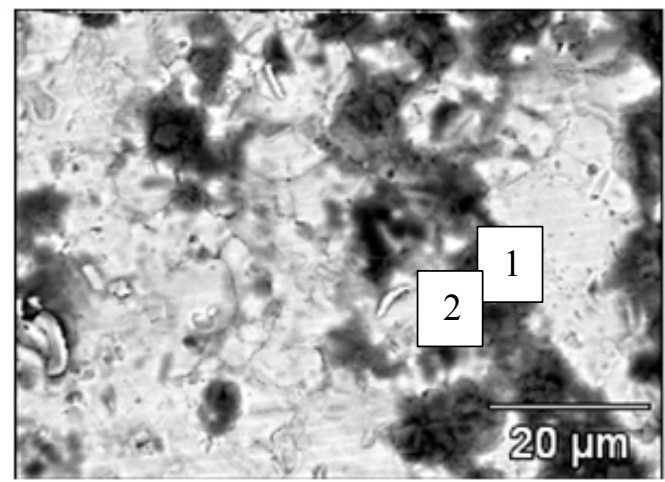

(a)
Full scale counts: $4500 \quad$ Base(69).pr1

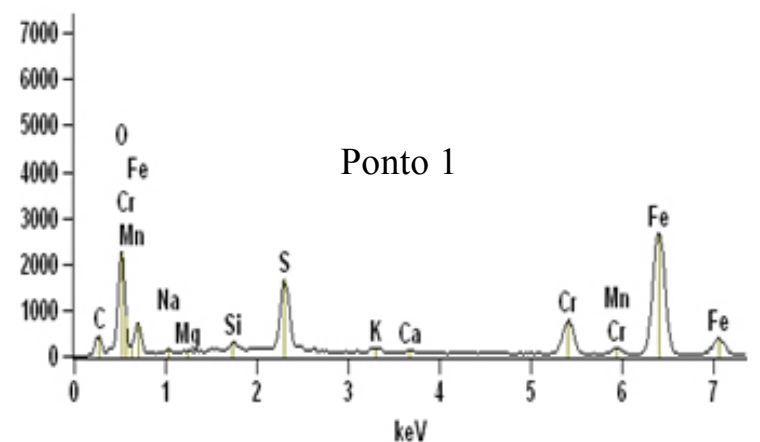

(b)

Figura 5.8: (a) Detalhe da região identificada pelo ponto 3 da Figura 5.5, feita com o MEV. (b) Espectro característico da região indicada pelo ponto $1 \mathrm{da}$ Figura 5.8 (a).

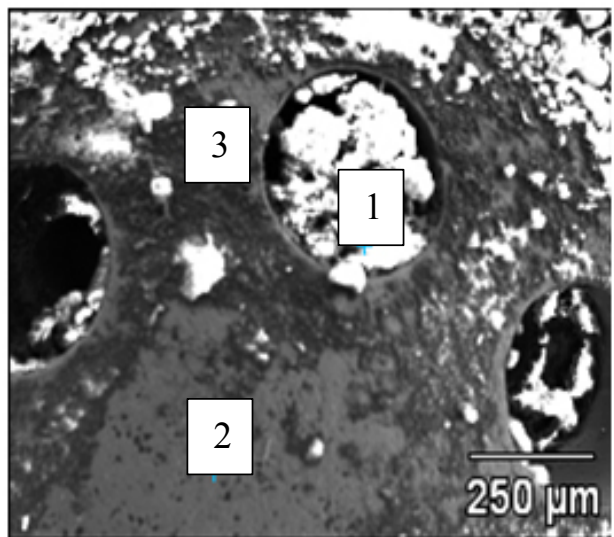

(a)

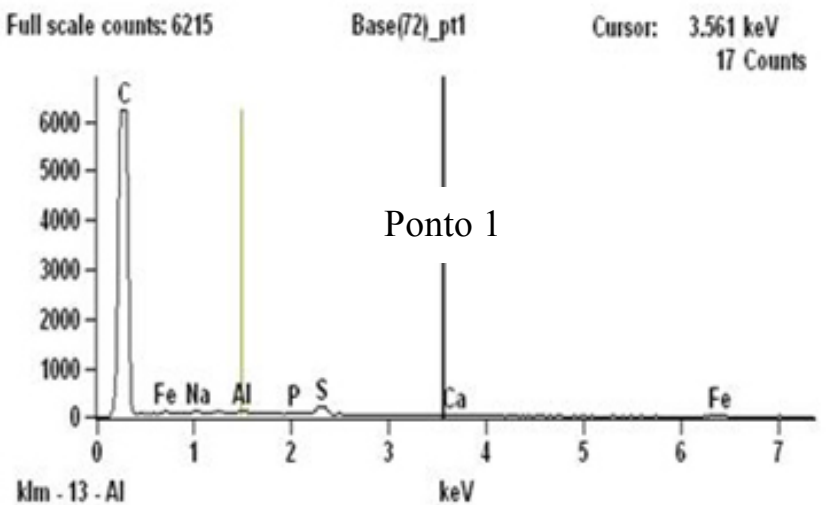

(b)

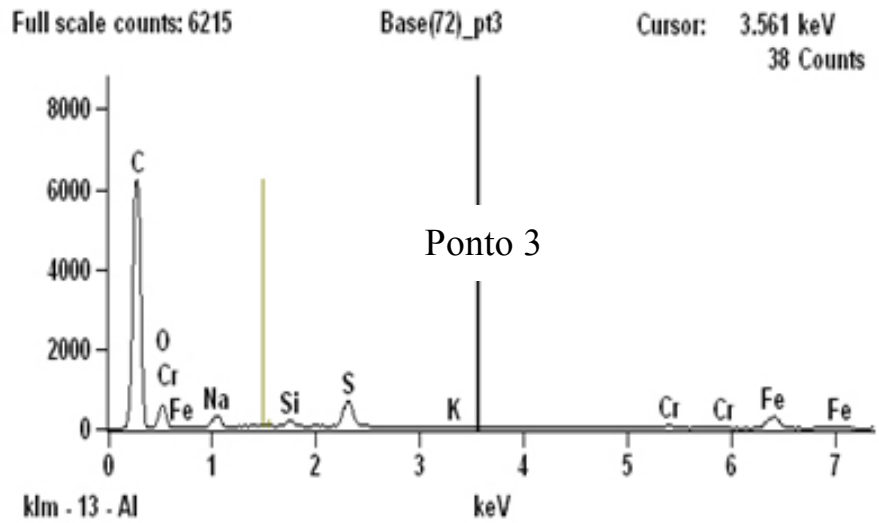

(c)

Figura 5.9: (a) Detalhe do injetor ilustrado na Figura 5.5. (b) Espectro da região especificada pelo ponto 1. (c) Espectro da região especificada pelo ponto 3 . 
Pode-se notar, através dos espectros apresentados, que o ponto 1, mostrado na Figura 5.9 (a), apresenta compostos ricos em carbono, enquanto o ponto 3 indica a presença de compostos ricos em carbono, oxigênio e enxofre, como notase através da Figura 5.9 (b).

É possível notar que os compostos observados são, basicamente, de duas composições distintas, como ilustrado no espectro apresentado acima. Um dos compostos é rico em carbono, com baixas concentrações de enxofre, oxigênio e sódio (Na), como mostrado na Figura 5.7 (c) e (d), correspondentes aos pontos 3 e 4 da Figura 5.6, e na Figura 5.9 (c), por exemplo. Por outro lado, outros depósitos apresentaram concentrações similares de carbono e enxofre, e baixas concentrações de sódio, como mostrado na Figura 5.8.

Para que se caracterizassem os depósitos contidos no interior dos furos do bico injetor, foi necessário que o injetor fosse seccionado longitudinalmente em uma de suas cavidades. Este seccionamento foi realizado utilizando uma máquina de corte de pequenas dimensões, sem adição de água. Desta forma, evitou-se a remoção dos depósitos.

A Figura 5.10, a seguir, ilustra a peça após ser cortada, assim como a vista lateral do corte.

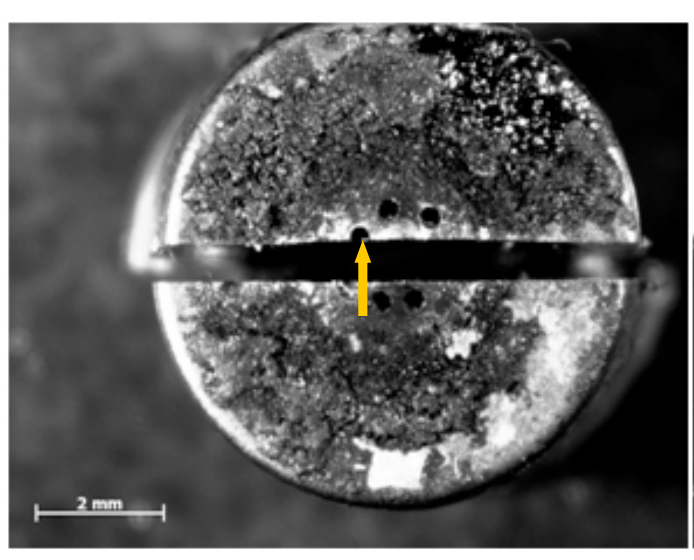

(a)

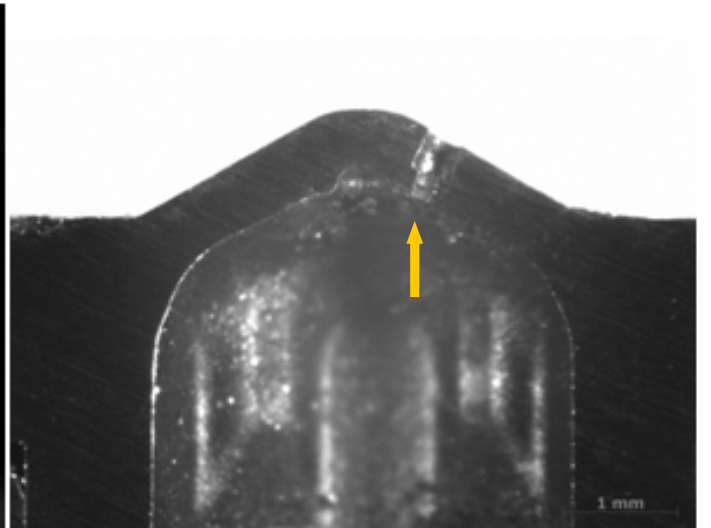

(b)

Figura 5.10: (a) Vista frontal do injetor depositado. Secção longitudinal. A seta indica a região analisada (Figuras 5.11 e 5.12). (b) Detalhe da secção longitudinal do injetor. 
A Figura 5.11 apresenta um ponto no interior da cavidade do injetor que foi analisado e seu espectro respectivo. Nota-se através da análise do espectro relativo ao ponto 1 que, além da alta concentração de carbono, existe a presença de concentrações relativamente altas de ferro e cromo. Estas concentrações podem estar diretamente ligadas a base metálica do material. Além destes compostos, existe, ainda, uma pequena concentração de enxofre.

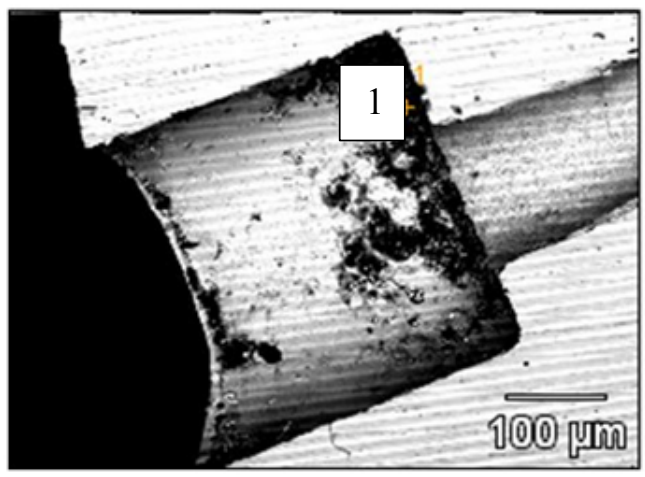

(a)

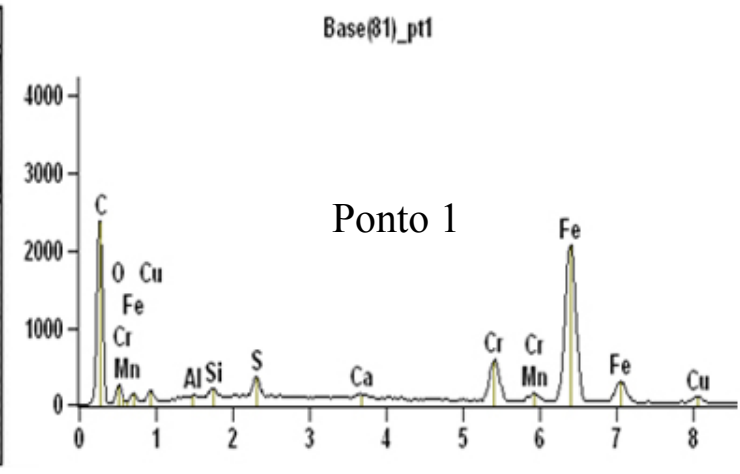

(b)

Figura 5.11: (a) Região identificada pela seta na Figura 5.10. (b) Espectro da região indicada pelo ponto 1 .

A Figura 5.12 apresenta uma região aproximada do interior do furo do bico injetor, mostrado na Figura 5.11, onde foram analisados dois pontos. $\mathrm{O}$ espectro apresenta, além das altas concentrações de carbono, ferro e cromo, uma alta concentração de enxofre. 


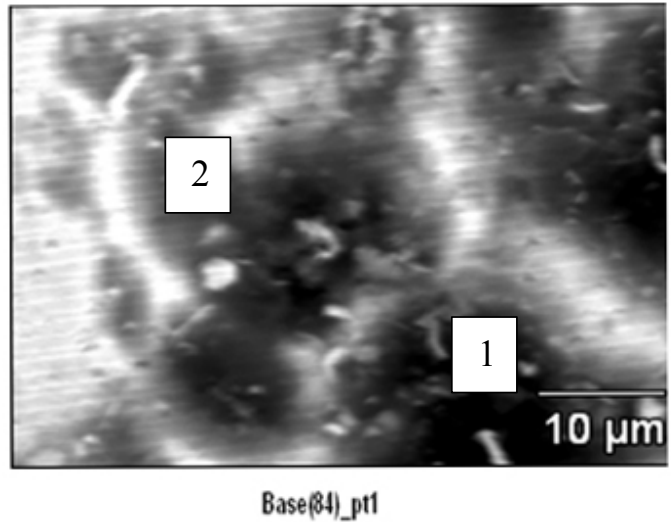

(a)

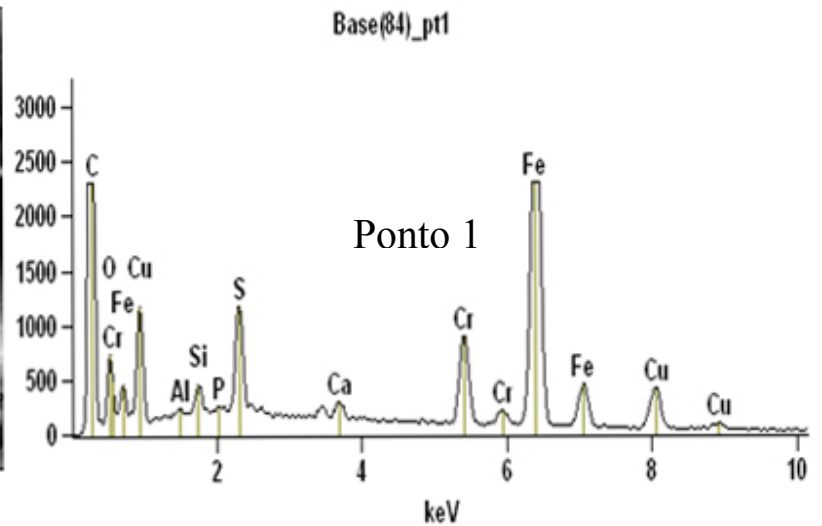

(b)

Figura 5.12: (a) Detalhe da região identificada por 1 na Figura 5.11.

Imagem feita com o MEV. (b) Espectro da análise da região indicada pelo ponto

Tendo em vista que parte dos depósitos analisados apresentou uma alta concentração de enxofre, optou-se por analisar os íons positivos e negativos presentes nas gasolinas testadas. Dessa forma foi possível quantificar, além do enxofre total proveniente da caracterização do combustível, a quantidade de sulfato presente no mesmo. O resultado obtido está demostrado nas Tabelas $5.2 \mathrm{e}$ 5.3 a seguir.

Tabela 5.2: Resultado da cromatografia de íons positivos - Gasolina CO

\begin{tabular}{|c|c|c|c|c|}
\hline Íons Positivos & $\mathrm{Na}^{+}(\mathrm{ppm})$ & $\mathrm{K}^{+}(\mathrm{ppm})$ & $\mathrm{Ca}^{2+}(\mathrm{ppm})$ & $\mathrm{Mg}^{2+}(\mathrm{ppm})$ \\
\hline Gasolina $\mathrm{CO}$ & 2,20 & 0,98 & 0,36 & 0,12 \\
\hline
\end{tabular}

Tabela 5.3: Resultado da cromatografia de íons negativos - Gasolina CO

\begin{tabular}{|c|c|c|c|c|c|c|}
\hline Íons Negativos & $\begin{array}{c}\mathrm{F}^{-} \\
(\mathrm{ppm})\end{array}$ & $\begin{array}{c}\mathrm{Cl}^{-} \\
(\mathrm{ppm})\end{array}$ & $\begin{array}{c}\mathrm{Br}^{-} \\
(\mathrm{ppm})\end{array}$ & $\begin{array}{c}\mathrm{NO}_{3^{-}} \\
(\mathrm{ppm})\end{array}$ & $\begin{array}{c}\mathrm{HPO}_{4}^{-2} \\
(\mathrm{ppm})\end{array}$ & $\begin{array}{c}\mathrm{SO}_{4}^{2^{-}} \\
(\mathrm{ppm})\end{array}$ \\
\hline Gasolina $\mathrm{CO}$ & $<0,01$ & 0,65 & 0,0048 & 0,074 & 0,038 & 0,79 \\
\hline
\end{tabular}




\subsection{Teste de vazão com temperaturas elevadas}

Para dar continuidade à investigação da formação de depósitos nos injetores de gasolina, foi realizado um ensaio com o objetivo verificar a influência da temperatura do bico injetor quanto a formação desses depósitos.

Com base na revisão bibliográfica feita para o trabalho, verificou-se a influência da temperatura do combustível na formação de depósitos cerosos no interior do bico injetor [5]. Quando a temperatura supera noventa por cento da temperatura de saturação do combustível, de aproximadamente $190^{\circ} \mathrm{C}$, pode-se haver gasolina vaporizada entre os pulsos de injeção, o que pode vir a facilitar a formação de camadas depositadas.

Para isso, foi adicionada à parede do bico injetor uma peça confeccionada de alumínio, onde três resistências do tipo bastão foram alocadas. A metodologia utilizada durante esse teste foi de aquecer o injetor até uma temperatura escolhida e, então, começar a pulsá-lo de acordo com os parâmetros pré-estabelecidos de injeção, conforme explicado no Capítulo 4. Ao longo do teste, ensaios de vazão foram realizados no injetor que estava sendo testado, a fim de verificar se o depósito estava ocorrendo, e caso houvesse a formação desse depósitos, quantificá-la em função da perda de vazão através do injetor.

A temperatura média lida através do termopar instalado na peça de alumínio durante os testes foi de $267^{\circ} \mathrm{C}$.

A Figura 5.13, a seguir, apresenta as medições de vazão feitas no injetor testado a cada $2.500 \mathrm{~km}$ simulados. 


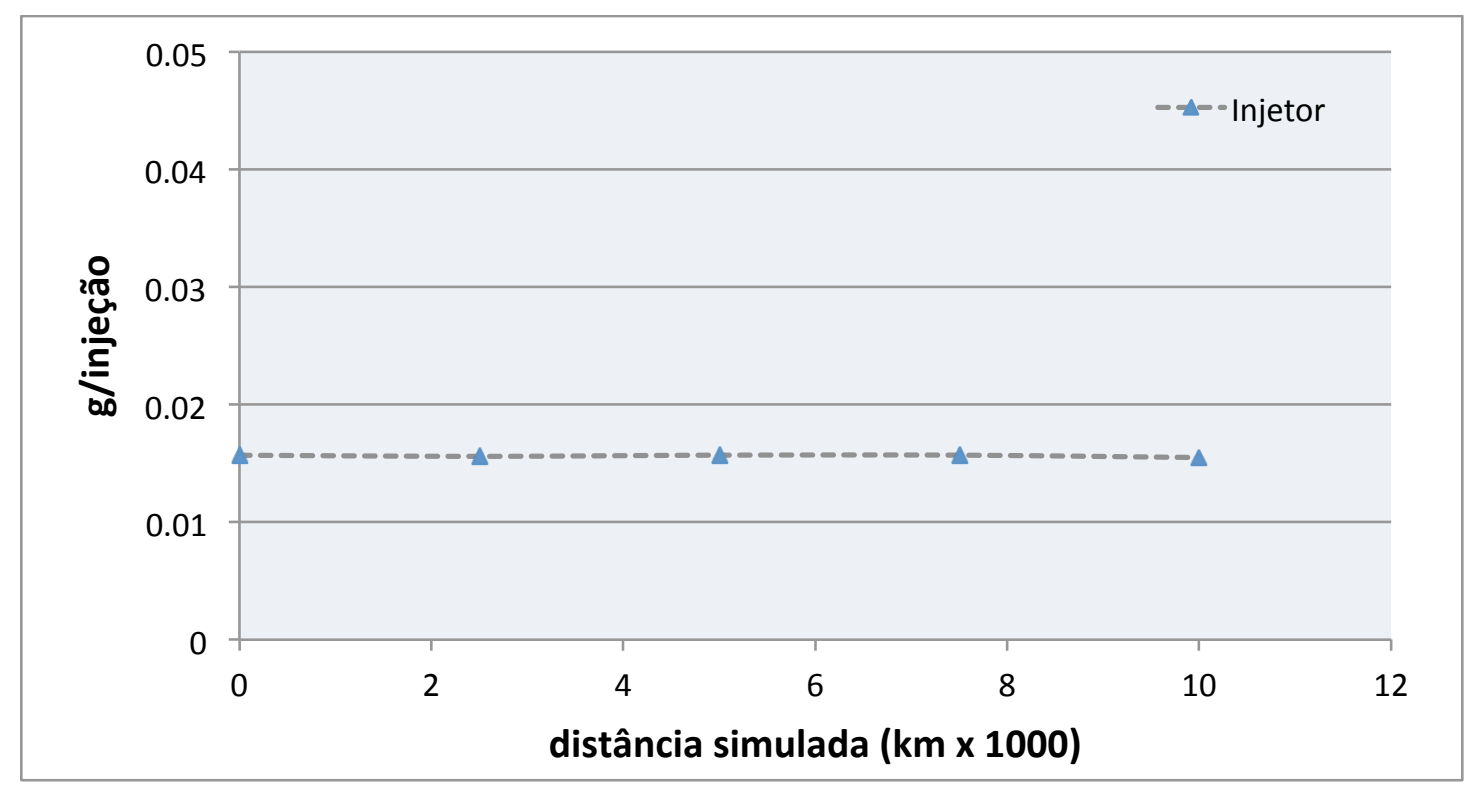

Figura 5.13: Massa injetada por distância simulada na bancada de vazão.

A partir do gráfico acima apresentado, pode-se notar que a massa de combustível injetada por pulso de injeção do bico testado não sofreu alterações significativas à medida que a quilometragem simulada foi aumentando. $\mathrm{O}$ pequeno desvio obtido nos resultados pode ser associado às incertezas na medição. Desta forma, é possível afirmar que não houve formação de depósitos durante os 10.000 km simulados na bancada de vazão.

Com base nos dados acima apresentados, conclui-se ser necessária a presença da combustão para o processo de formação de depósitos nos bicos injetores de motores com injeção direta de gasolina. Pode-se atribuir este fato ao gradiente de temperatura em que a superfície externa do injetor é submetido, assim como a pressão dentro da câmara de combustão.

\subsection{Dinamômetro de chassis - primeira etapa}

$\mathrm{Na}$ primeira etapa de ensaios realizados no dinamômetro de chassis, utilizando o veículo Peugeot 3008, foram feitos dez testes. Para isso, aproximadamente $33.000 \mathrm{~km}$ foram rodados, totalizando assim aproximadas 825 horas de testes. 
A tabela a seguir quantifica e apresenta um breve resumo dos ensaios realizados e suas devidas observações.

Tabela 5.4: Relação de testes realizados durante a primeira etapa de ensaios no dinamômetro de chassis

\begin{tabular}{|c|c|c|c|c|}
\hline TESTE & СОМB & $\begin{array}{l}\text { DIST. } \\
\text { [km] }\end{array}$ & FRA Final & Observações \\
\hline T1 & C1 & 8.163 & ND & Teste sem monitoramento contínuo do FRA \\
\hline T2 & $\mathrm{C} 1 / \mathrm{C} 2$ & 10.109 & 1,247437 & Teste com monitoramento contínuo do FRA \\
\hline $\mathrm{T} 2 \mathrm{C}$ & $\mathrm{C2}$ & 6.085 & 1,299988 & Continuação do T2 \\
\hline T3 & C3 & 1.053 & 1,300000 & Problema na bomba de baixa pressão \\
\hline T4 & C3 & 350 & 1,100000 & Teste parado com $350 \mathrm{~km}$ em função do alto FRA \\
\hline T4C & C3 & 1.833 & 1,292480 & Continuação do teste T4 \\
\hline T5 & C4 & 3.166 & 1,299000 & Alto valor de FRA com baixa quilometragem \\
\hline T6 & C2 & 102 & 1,293823 & Teste de reaprendizado rápido do FRA \\
\hline T7 & C4 & 103 & ND & Teste de reaprendizado rápido do FRA \\
\hline T8 & $\mathrm{C} 4$ & 102 & ND & Teste de reaprendizado rápido do FRA \\
\hline T9 & C4 & 379 & ND & Teste de reaprendizado rápido do FRA \\
\hline T10 & C3 & 1.024 & 1,299347 & Alto valor de FRA com baixa quilometragem \\
\hline
\end{tabular}

Os combustíveis C1 a C4 estão especificados/analisados, a seguir, nos itens 5.3.1 em diante, referentes aos resultados dos testes.

Verificou-se ao longo de alguns dos testes (T3 a T5, por exemplo), que a variável referente a adaptação do tempo de injeção (FRA) estava alcançando valores maiores do que 1,1 para quilometragens muito baixas. Ou seja, as vezes como menos de 100 km rodados, o fator de correção de injeção já estava próximo a $10 \%$. Tendo isto em vista, foi necessário verificar a origem deste problema, para que os testes continuassem. Primeiramente, foi verificado se tal problema era de natureza química, devido a alguma diferença na composição do combustível entre os testes, o que afetaria a estequiometria, variando assim o tempo de injeção. 
Para isso, foi desenvolvida uma metodologia rápida de aprendizado do FRA, onde os adaptativos da central eletrônica eram zerados e em seguida o veículo permanecia 5 minutos em regime de marcha lenta. Em seguida 100km eram percorridos, no dinamômetro de chassis, à uma velocidade de $100 \mathrm{~km} / \mathrm{h}$. Esta metodologia foi realizada, primeiramente, para duas gasolinas diferentes (C2 e C4), nos testes T6 e T7. Desta forma, se o FRA tivesse o mesmo comportamento para ambos os combustíveis, o problema poderia ser de origem física, e não química.

A tendência do crescimento acelerado do FRA foi observada durante os dois testes (T6 e T7), o que levou a crer que o problema poderia ser de origem física, proveniente do mal funcionamento de algum componente do motor nos testes. Dois componentes que poderiam influenciar a relação ar/combustível do motor foram testados: a sonda lambda e o corpo de borboleta. A sonda lambda poderia estar enviando um sinal errado para a central eletrônica e assim a UCE tentaria reparar o problema aumentando o tempo de injeção (através do FRA). Já o corpo de borboleta, se não estivesse funcionando perfeitamente, poderia estar restringindo mais ou menos do que deveria a passagem de ar, e assim afetaria o funcionamento do motor.

Portanto, para verificar se o problema estava em um dos componentes citados, fixou-se o combustível (C4) e os mesmos foram variados para os testes T8 e T9. A tendência se repetiu, mesmo com os componentes trocados.

Mais um teste foi realizado com o veículo Peugeot 3008 (T10), utilizando a gasolina C4. Desta vez o ensaio realizado foi o convencional, cuja metodologia está descrita no Capítulo 4, e o teste novamente apresentou um alto valor de FRA para uma quilometragem baixa. Em função disto, optou-se por trocar o veículo.

Portanto, os testes de maior significado para esta primeira etapa foram T1 e T2/T2C, apresentados a seguir.

\subsubsection{Dinamômetro de chassis - Peugeot 3008 - combustível C1}

O primeiro teste realizado no dinamômetro de chassis utilizou o combustível $\mathrm{C} 1$, não contou com o monitoramento constante do FRA, uma vez que o equipamento necessário ainda não havia sido adquirido. Sabia-se que 
quando o veículo atingia o nível máximo de correção na injeção, sua central eletrônica entrava em regime de segurança e o motor parava de trabalhar de maneira otimizada, não acionando a turbina. Sendo assim, o ensaio foi encerrado assim que tal fato foi verificado.

Conforme demonstrado na Tabela 5.5, a seguir, o veículo chegou a 8.163 $\mathrm{km}$ rodados.

Tabela 5.5: Informações do primeiro ensaio realizado em dinamômetro.

\begin{tabular}{|c|c|c|c|}
\hline TESTE & COMB. & DIST. & FRA Final \\
\hline T1 & C1 & 8.163 & ND \\
\hline
\end{tabular}

Em paralelo ao ensaio no dinamômetro de rolo, foi realizada a caracterização do combustível C1, segundo a metodologia descrita no Capítulo 3. Os resultados da caracterização estão apresentados na tabela 5.6, a seguir.

Tabela 5.6: Caracterização da gasolina C1.

\begin{tabular}{|c|c|}
\hline & Gasolina C1 \\
\hline Goma Lavada (mg/100 mL) & 1,2 \\
\hline Enxofre Total (ppm) & 523 \\
\hline Teor Alcoólico \%V/V & 25 \\
\hline Água (mg/kg) & 1317 \\
\hline Olefina (\%) & 13,5 \\
\hline Saturado (\%) & 46 \\
\hline Aromático (\%) & 15,3 \\
\hline Benzeno (\%) & 0,8 \\
\hline IAD & 88,2 \\
\hline
\end{tabular}

Analisando os resultados acima apresentados, todos os valores observados estão dentro dos limites estipulados pela resolução da ANP, $N^{\circ} 7$ de 2011.

A partir da constatação obtida após a caracterização dos depósitos formados no Road Test preliminar, as análises de íons positivos e negativos passaram a ser feitas para todos os combustíveis, juntamente com a caracterização dos mesmos. As Tabelas seguintes, 5.7 e 5.8, apresentam os resultados obtidos para a gasolina C1. 
Tabela 5.7: Resultado da análise de cátions realizada para a gasolina C1.

\begin{tabular}{|c|c|c|c|c|}
\hline Íons Positivos & $\mathrm{Na}^{+}(\mathrm{ppm})$ & $\mathrm{K}^{+}(\mathrm{ppm})$ & $\mathrm{Ca}^{2+}(\mathrm{ppm})$ & $\mathrm{Mg}^{2+}(\mathrm{ppm})$ \\
\hline Gasolina $C l$ & 2,20 & 0,88 & 0,41 & 0,12 \\
\hline
\end{tabular}

Tabela 5.8: Resultado da análise de ânions realizada para a gasolina C1.

\begin{tabular}{|c|c|c|c|c|c|c|}
\hline Íons Negativos & $\begin{array}{c}\mathrm{F}^{-} \\
(\mathrm{ppm})\end{array}$ & $\begin{array}{c}\mathrm{Cl}^{-} \\
(\mathrm{ppm})\end{array}$ & $\begin{array}{c}\mathrm{Br}^{-} \\
(\mathrm{ppm})\end{array}$ & $\begin{array}{c}\mathrm{NO}_{3^{-}} \\
(\mathrm{ppm})\end{array}$ & $\begin{array}{c}\mathrm{HPO}_{4}^{-2} \\
(\mathrm{ppm})\end{array}$ & $\begin{array}{c}\mathrm{SO}_{4}^{{ }^{-}} \\
(\mathrm{ppm})\end{array}$ \\
\hline Gasolina $C 1$ & $<0,01$ & 0,68 & 0,0048 & 0,074 & 0,043 & 0,79 \\
\hline
\end{tabular}

Pode-se perceber que o valor de sulfato encontrado para o combustível $\mathrm{C} 1$ foi o mesmo visto na gasolina $\mathrm{C} 0(0,79 \mathrm{ppm})$. Este fato indica que a formação dos depósitos ocorrida nos Road Tests preliminares, assim como no primeiro teste elaborado no dinamômetro de chassis, pode estar atribuída a quantidade de sulfato presente nos combustíveis $(\mathrm{C} 0$ e $\mathrm{C} 1)$.

Assim como realizado nos bicos injetores utilizados no Road Test preliminar, os bicos injetores retirados do veículo após o ensaio no dinamômetro de chassis também tiveram seus depósitos caracterizados quimicamente. As Figuras 5.13 a 5.17 ilustram os resultados obtidos.

A Figura 5.14, a seguir, mostra o aspecto visual de um dos bicos injetores após ensaio realizado com veiculo Peugeot 3008 no dinamômetro de chassis utilizando o combustível identificado como $\mathrm{C} 1$.

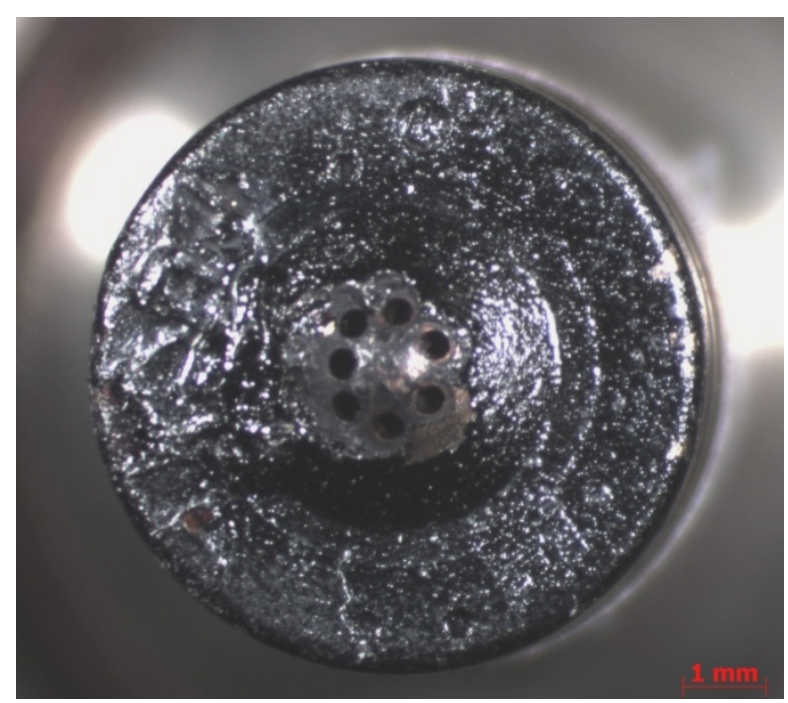

Figura 5.14: Vista frontal do bico (imagem utilizando lupa estereoscópica). 
A Figura 5.15 (a) apresenta as imagens feitas pelo Microscópio Eletrônico de Varredura (MEV) de um injetor utilizado no ensaio realizado no dinamômetro de chassis. Pode-se notar a região dos furos do bico injetor de forma detalhada. Nesta imagem é possível visualizar a formação de depósitos, alojados nas cavidades do injetor e em sua superfície externa. A Figura 5.15 (b) apresenta, ainda, um dos furos do bico injetor e os seis pontos que tiveram suas concentrações quimicamente analisadas. A Figura 5.16, por sua vez, apresenta os espectros referentes aos pontos 1 e 6 da Figura 5.14 (b).

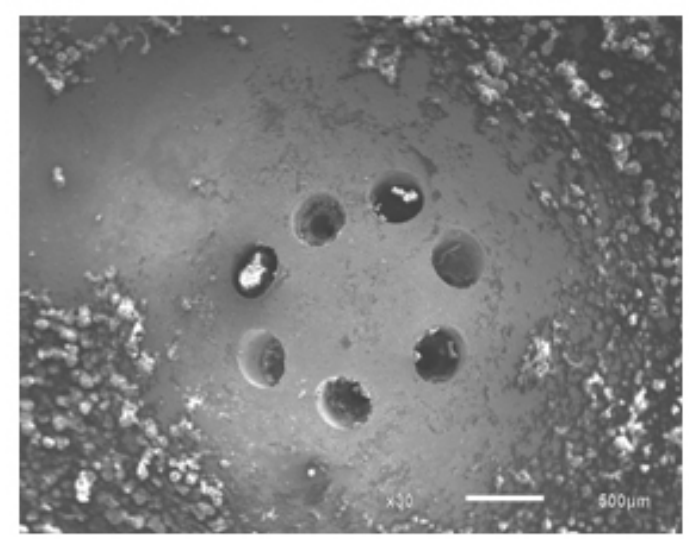

(a)

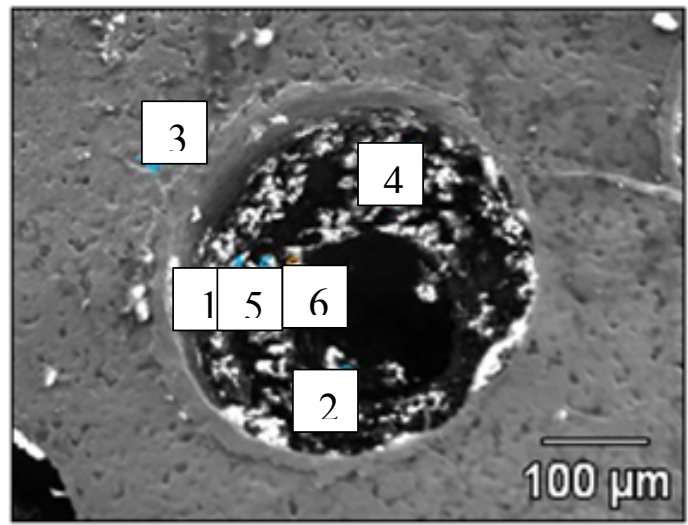

(b)

Figura 5.15: (a) Região dos furos do bico injetor; (b) Imagem detalhada de um furo e os pontos analisados utilizando o MEV.
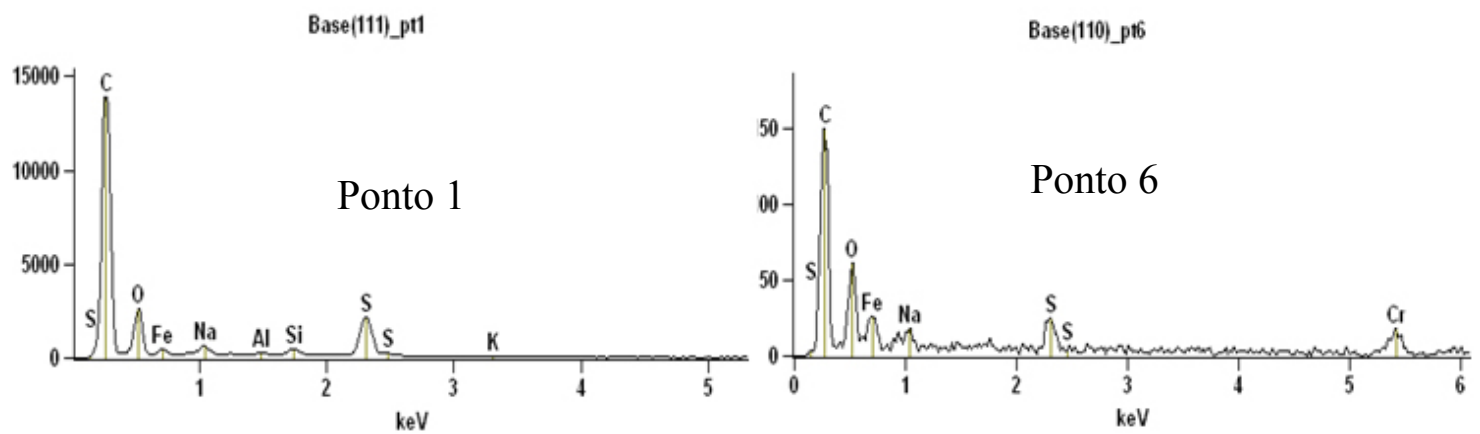

Figura 5.16: Espectros referentes aos pontos 1 e 6 do furo analisado (Figura $5.15)$. 
Pode-se notar, a partir dos espectros relativos aos pontos 1 e 6 da Figura 5.15(b), acima apresentados, a presença de compostos ricos em oxigênio e enxofre além de uma grande concentração de carbono. Os outros pontos analisados apresentaram espectros semelhantes aos obtidos nos pontos 1 e 6 .

A Figura 5.17 (a) detalha um orifício de um injetor utilizado durante o ensaio, assim como o ponto em que teve sua composição analisada. O espectro relativo a este ponto está apresentado na Figura 5.17 (b).

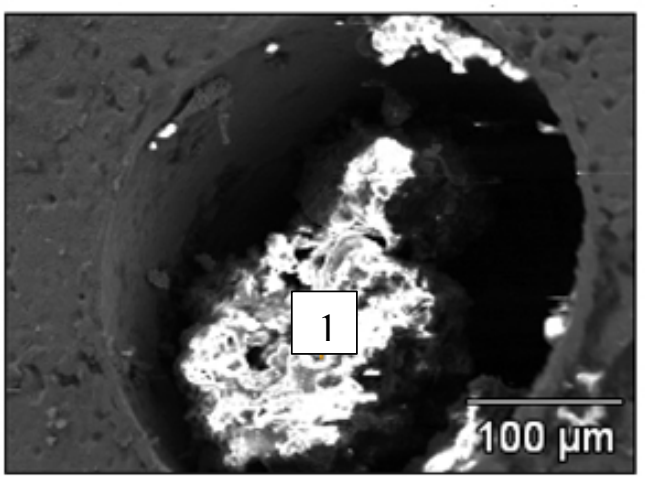

(a)

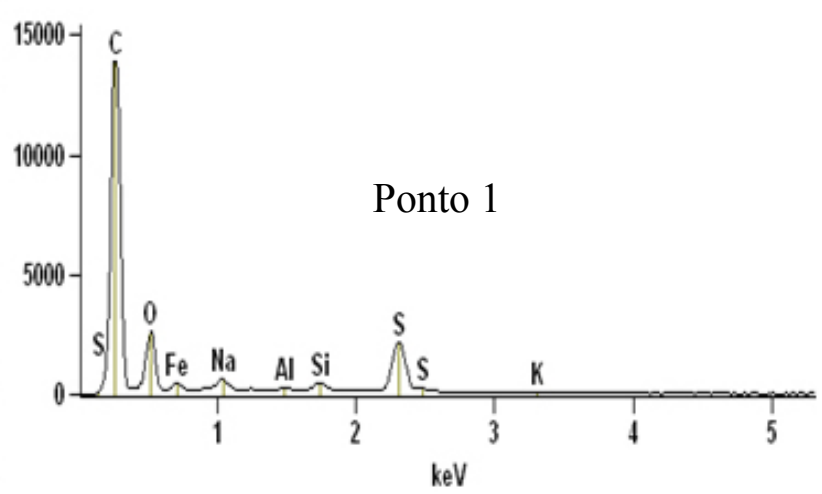

(b)

Figura 5.17: (a) Detalhe de outro furo ilustrado nas Figuras 5.14 e 5.15, imagem por microscopia eletrônica de varredura; (b) Espectro referente à análise realizada na região indicada por 1 .

Primeiramente, é possível verificar uma grande concentração de carbono presente no ponto analisado. Em seguida, são notados também compostos ricos em oxigênio e enxofre, assim como nos pontos analisados e apresentados na Figura 5.16.

De maneira análoga ao que se foi feito com os injetores utilizados no Road Test preliminar, um dos bicos retirados do ensaio no dinamômetro de chassis foi seccionado longitudinalmente, em uma das cavidades de passagem de gasolina. Desta forma foi possível que se realizasse uma caracterização dos depósitos formados na cavidade interior do injetor. A Figura 5.18, a seguir, apresenta esta secção transversal de um furo do injetor e os pontos que tiveram suas concentrações analisadas, através da metodologia descrita no Capitulo 4. Ainda na mesma figura se encontra o espectro de concentrações de um dos pontos, realizado com o microscópio eletrônico de varredura. 


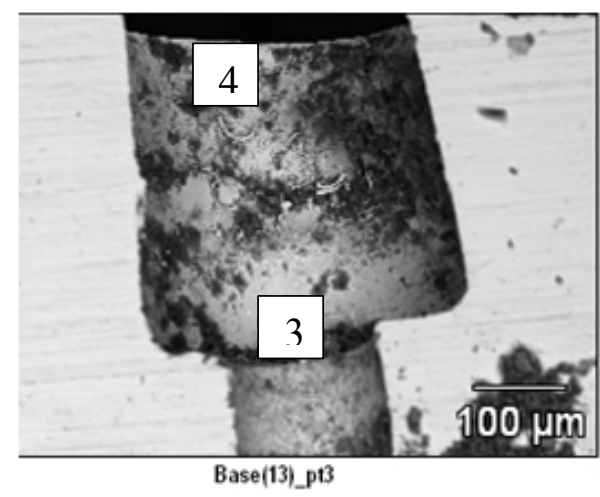

(a)

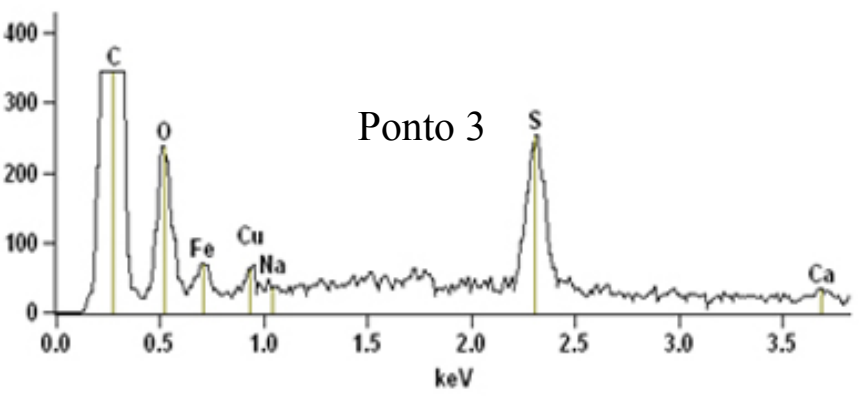

(b)

Figura 5.18: (a) Seção transversal de um bico injetor; (b) Espectro referente à análise da região indicada.

O espectro (Figuras 5.18 b), acima apresentado, demonstra a presença de altas concentrações de carbono, oxigênio e enxofre.

Os resultados obtidos durante a caracterização dos depósitos encontrados nos injetores de gasolina ao término do ensaio no dinamômetro foram próximos ao que foi visto durante o Road Test preliminar. Em alguns pontos notou-se uma alta concentração de carbono (Figura 5.17, por exemplo), enquanto em outros pontos apresentaram compostos ricos, também, em enxofre e oxigênio (Figura $5.18)$.

\subsubsection{Dinamômetro de chassis - Peugeot 3008 - combustíveis C1/C2}

Durante os primeiros ensaios realizados, levantou-se a possibilidade de que a linha de combustível do veículo, neste caso de borracha, poderia favorecer a formação dos depósitos alojados no interior dos injetores de combustível. Isso poderia acontecer devido ao fato da gasolina, ao passar pelas bombas de baixa e alta pressão, ter sua temperatura elevada e assim atingir valores próximos a 90\% da temperatura de saturação, como visto na revisão bibliográfica.

Para verificar a influência do material da linha de combustível neste processo, a mesma foi substituída por uma inteiramente de aço inox. Para que isso fosse possível, foi necessário substituir a bomba de baixa pressão por um vaso de 
pressão. Para garantir que o combustível chegasse aos 4,5 bar necessários na linha de baixa pressão, o vaso foi pressurizado com nitrogênio. Conforme mostrado na Figura 5.19, a seguir.

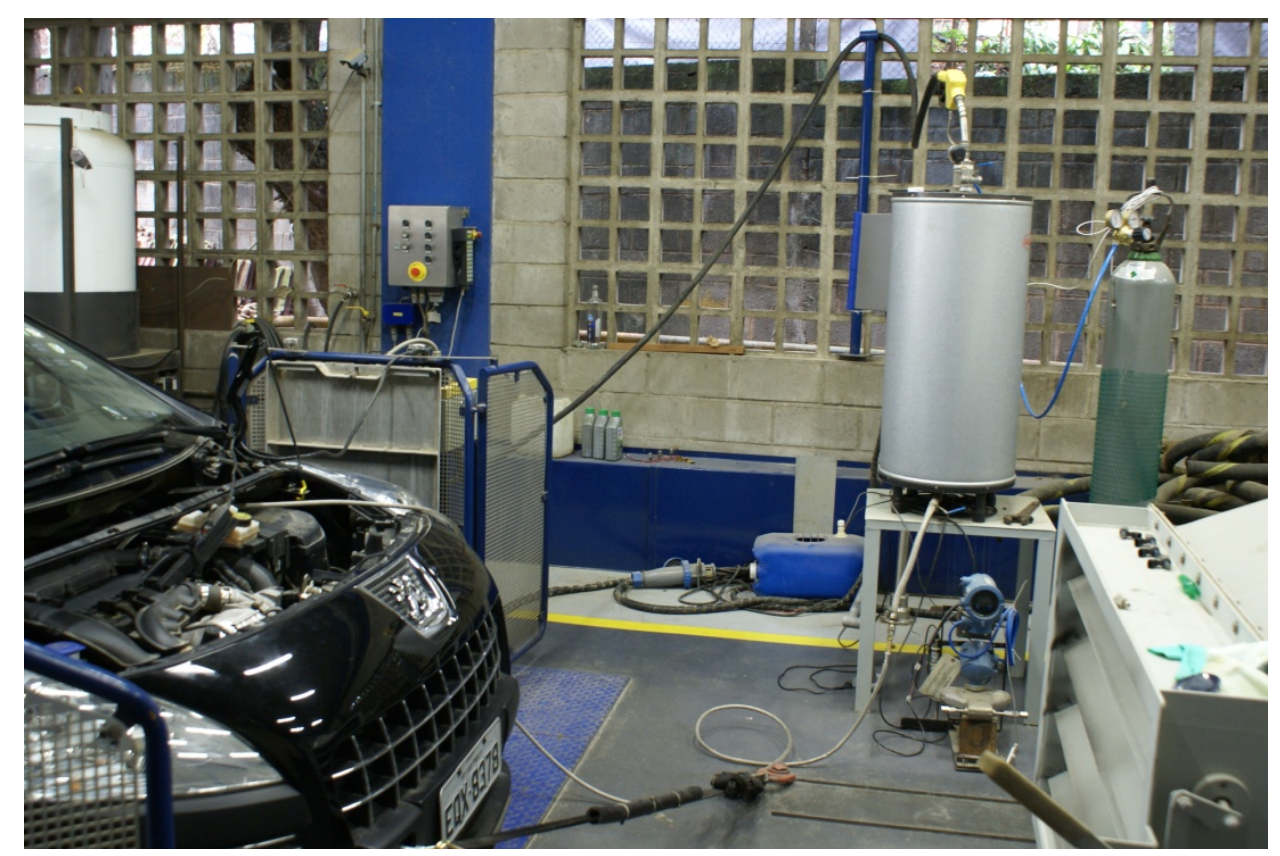

Figura 5.19: Veículo sendo testado com linha de combustível toda metálica.

Verificou-se ao longo do ensaio que, mesmo com a linha de combustível metálica, a variável FRA atingiu seu valor limite com $16.194 \mathrm{~km}$ rodados. Neste teste já foi realizado o acompanhamento contínuo do FRA. Diferentemente dos ensaios realizados no Road Test preliminar, onde o valor da variável de adaptação do tempo de injeção era coletada a cada mil quilômetros, nos testes no dinamômetro de chassis sua gravação era realizada a cada minuto.

Em função desta diferença, os resultados da variável FRA nos testes do dinamômetro serão fornecidos em função do tempo (horas), e não mais da quilometragem. O resultado do teste elaborado com a linha de combustível metálica está apresentado na Figura 5.20, a seguir. 


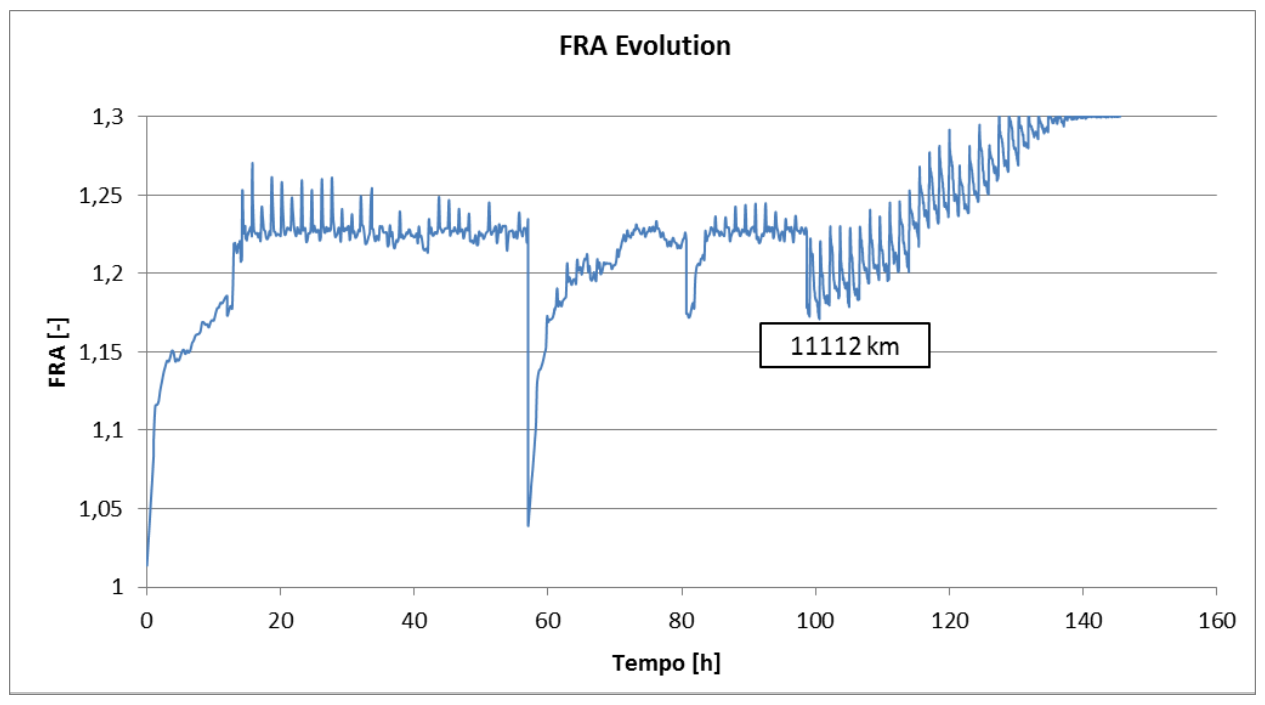

Figura 5.20: Acompanhamento contínuo da variável de adaptação do tempo de injeção ao longo do ensaio realizado com a gasolina $C 1$.

É importante ressaltar que quando o veículo atingiu os $10.000 \mathrm{~km}$ onde, segundo a metodologia adotada, o teste deveria terminar, o valor de FRA estava aproximadamente 1,2. Devido a este fato, optou-se por rodar mais e verificar se o FRA iria se manter estável ou continuaria subindo. Em função dessa escolha, o veículo chegou a percorrer os $16.194 \mathrm{~km}$, quando atingiu o FRA de aproximadamente 1,3 .

$\mathrm{O}$ ensaio foi iniciado utilizando o mesmo combustível do teste anterior, $\mathrm{C} 1$. No ponto relativo a $11.112 \mathrm{~km}$ rodados o combustível acabou. Mais gasolina foi encomendada, com o mesmo fornecedor, sem dopagem extra de sulfato, para dar continuidade ao teste. Este combustível foi chamado de C2.

Pode-se perceber, observando o gráfico acima, que no decorrer do teste a variável de adaptação do tempo de injeção sofreu uma queda brusca e teve seu valor reduzido a aproximadamente 1 , e em seguida retomou seu valor de 1,2. Isso aconteceu porque, neste ponto do teste, foi necessário zerar os erros contidos na central eletrônica do veiculo. Com isso, os adaptativos também tem seus valores zerados, mas com a continuidade do ensaio os valores são rapidamente reaprendidos e voltam aos valores anteriores.

O resultado da caracterização feita para a gasolina C2 está apresentado na Tabela 5.9, a seguir: 
Tabela 5.9: Caracterização da gasolina C2.

\begin{tabular}{|c|c|}
\hline & Gasolina C2 \\
\hline Goma Lavada (mg/100 $\mathrm{mL})$ & 7 \\
\hline Enxofre Total & 619,3 \\
\hline Teor Alcoólico \%V/V & 25 \\
\hline Água (mg/kg) & 1744 \\
\hline Olefina (\%) & 14,3 \\
\hline Saturado (\%) & 46,1 \\
\hline Aromático (\%) & 14,8 \\
\hline Benzeno (\%) & 0,3 \\
\hline IAD & 87,9 \\
\hline
\end{tabular}

Como a gasolina $\mathrm{C} 2$, foi encomendada com o mesmo fornecedor da gasolina $\mathrm{C} 1$, não foi necessário a realização da caracterização de íons positivos e negativos para este combustível.

Tendo em vista que o veículo atingiu, novamente, o valor máximo da adaptação do tempo de injeção, de aproximadamente $30 \%$, surgiu então a necessidade de quantificar a perda de vazão proveniente dos depósitos formados. Desta forma, seria possível relacionar a quantidade de sulfato dosado ao combustível com o valor da variável de adaptação do tempo de injeção (FRA) e a perda de vazão proveniente dos depósitos formados nos injetores de combustível.

\subsection{Dinamômetro de chassis - segunda etapa}

A segunda etapa de testes feitos no dinamômetro de chassis foi realizada utilizando um Peugeot 408, equipado com o mesmo motor do veículo anterior. Desta forma foi possível correlacionar os resultados dos ensaios.

Nesta fase, foram realizados duas provas, totalizando $11.575 \mathrm{~km}$ rodados em aproximadamente 290 horas de testes. Conforme citado anteriormente, durante os ensaios realizados para a segunda etapa foram feitas, além do monitoramento contínuo do FRA, medições de vazão nos injetores após o término de cada teste. 
Tabela 5.10: Resumo dos testes realizados na segunda fase do dinamômetro de chassis.

\begin{tabular}{|c|c|c|c|l|}
\hline TESTE & COMB & DIST.[km] & FRA Final & \multicolumn{1}{c|}{ Observações } \\
\hline T11 & C2 & 7.370 & 1,2999 & $\begin{array}{l}\text { Teste com monitoramento do FRA e teste de } \\
\text { vazão }\end{array}$ \\
\hline T12 & C3 & 4.205 & 1,2995 & $\begin{array}{l}\text { Teste com monitoramento do FRA e teste de } \\
\text { vazão }\end{array}$ \\
\hline
\end{tabular}

\subsubsection{Dinamômetro de chassis - Peugeot 408 - combustível C2}

É possível notar, através do resultado apresentado a seguir que, para o ensaio realizado com o combustível $\mathrm{C} 2$, a variável $F R A$ teve seu valor limite alcançado com aproximadamente $7.370 \mathrm{~km}$. Diferentemente dos últimos testes realizados na primeira etapa (Peugeot 3008), com o veículo 408, a adaptação do tempo de injeção não atinge o valor de 1,1 com uma pequena quilometragem de teste.

A Figura 5.21, a seguir, mostra a tendência do FRA desde o início do ensaio, onde seu valor era próximo a 1, até o final, quando alcança 1,299.

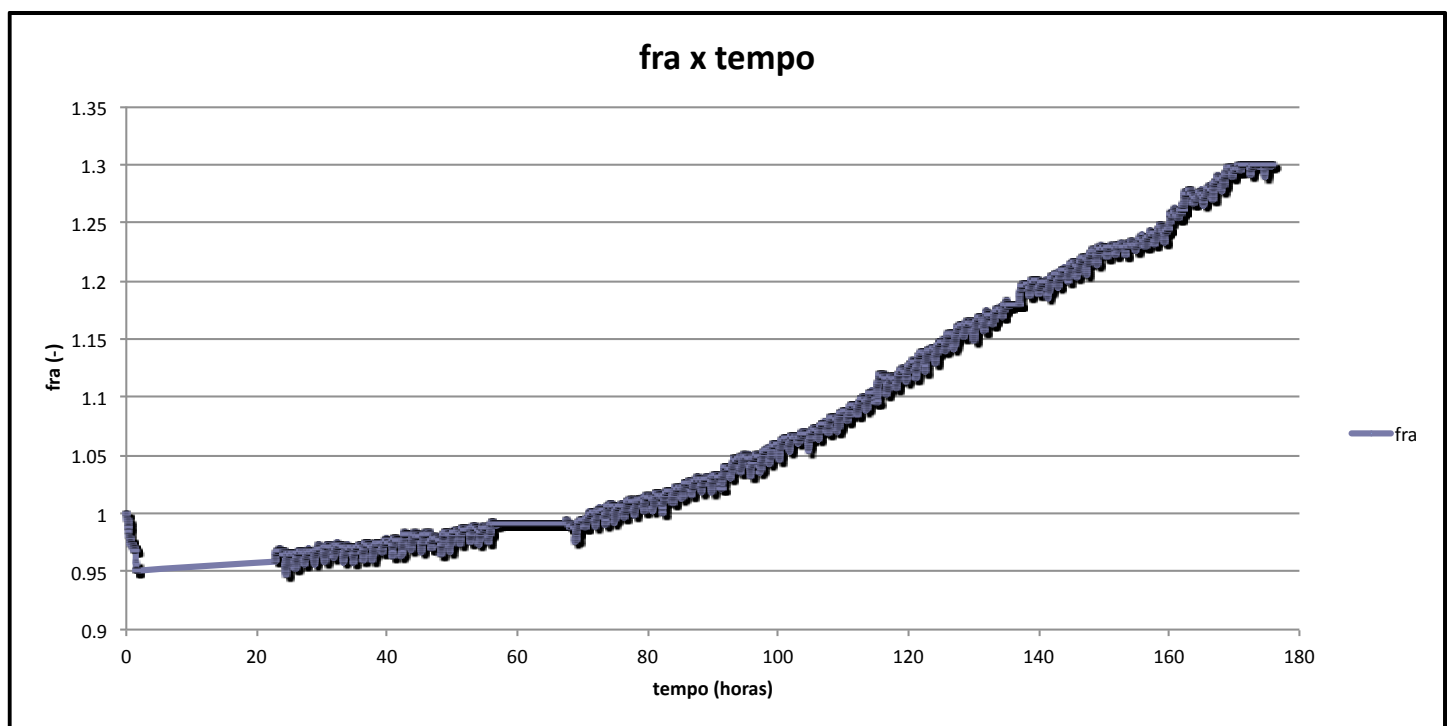

Figura 5.21: Acompanhamento contínuo do FRA ao longo do ensaio realizado com a gasolina $C 2$. 
Antes do ensaio, a gasolina $C 2$ foi novamente caracterizada devido ao tempo de estocagem entre os ensaios que utilizaram esta gasolina. Esta caracterização foi feita com o intuito de verificar as variações em características como teor de goma lavada, enxofre total, entre outros.

Os resultados obtidos estão apresentados na Tabela 5.11, a seguir:

Tabela 5.11: Caracterização da gasolina C2.

\begin{tabular}{|c|c|}
\hline & Gasolina C2 \\
\hline Goma Lavada (mg/100 mL) & 6,6 \\
\hline Enxofre Total & 588 \\
\hline Teor Alcoólico \% V/V & 25 \\
\hline Água (mg/kg) & 1465,3 \\
\hline Olefina (\%) & 14,6 \\
\hline Saturado (\%) & 43,5 \\
\hline Aromático (\%) & 15,8 \\
\hline Benzeno (\%) & 0,3 \\
\hline MON + RON & 88,7 \\
\hline
\end{tabular}

Novamente a análise realizada prova que o combustível C2 formulado respeita os limites impostos pelas especificações da resolução $\mathrm{N}^{\circ} 7$ da $\mathrm{ANP}$, de 2011, com exceção do teor de goma lavada, que se encontra acima do valor proposto pela norma.

Desta vez, foram realizadas também as análises de íons positivos e negativos das amostras coletadas de gasolina, conforme mostrado a seguir:

Tabela 5.12: Análise de íons positivos do combustível C2.

\begin{tabular}{|c|c|c|c|c|}
\hline Íons Positivos & $\mathrm{Na}^{+}(\mathrm{ppm})$ & $\mathrm{K}^{+}(\mathrm{ppm})$ & $\mathrm{Ca}^{2+}(\mathrm{ppm})$ & $\mathrm{Mg}^{2+}(\mathrm{ppm})$ \\
\hline Gasolina $C 2$ & 2,20 & 0,98 & 0,36 & 0,12 \\
\hline
\end{tabular}

Tabela 5.13: Análise de íons negativos do combustível C2.

\begin{tabular}{|c|c|c|c|c|c|c|}
\hline Íons Negativos & $\begin{array}{c}\mathrm{F}^{-} \\
(\mathrm{ppm})\end{array}$ & $\begin{array}{c}\mathrm{Cl}^{-} \\
(\mathrm{ppm})\end{array}$ & $\begin{array}{c}\mathrm{Br}^{-} \\
(\mathrm{ppm})\end{array}$ & $\begin{array}{c}\mathrm{NO}_{3^{-}} \\
(\mathrm{ppm})\end{array}$ & $\begin{array}{c}\mathrm{HPO}_{4}^{-2} \\
(\mathrm{ppm})\end{array}$ & $\begin{array}{c}\mathrm{SO}_{4}^{2^{-}} \\
(\mathrm{ppm})\end{array}$ \\
\hline Gasolina $C 2$ & $<0,01$ & 0,65 & 0,0048 & 0,074 & 0,038 & 0,79 \\
\hline
\end{tabular}


Mais uma vez, acredita-se poder atribuir o alto valor de FRA atingido ao valor de sulfato dosado no combustível (0,79 ppm).

Para realizar uma análise quantitativa da perda de vazão referente ao acúmulo de depósito nos bicos foi realizado um ensaio na bancada de vazão, conforme apresentado nos seguintes resultados.

Tabela 5.14: Resultado do teste de vazão feito nos bicos injetores após o teste em dinamômetro de chassis com o combustível C2.

\begin{tabular}{|c|c|c|c|c|}
\hline \multicolumn{5}{|c|}{ Percentual de vazão dos injetores utilizados no ensaio com a gasolina C2 (\%) } \\
\hline $\begin{array}{c}\text { Tempo de } \\
\text { injeção }\end{array}$ & Cilindro 1 & Cilindro 2 & Cilindro 3 & Cilindro 4 \\
\hline $2,5 \mathrm{~ms}$ & 94,66 & 88,07 & 96,44 & 82,91 \\
\hline $3,5 \mathrm{~ms}$ & 95,06 & 89,48 & 96,83 & 83,79 \\
\hline $4,5 \mathrm{~ms}$ & 96,15 & 90,43 & 97,92 & 84,61 \\
\hline $5,5 \mathrm{~ms}$ & 95,65 & 90,49 & 90,49 & 85,99 \\
\hline
\end{tabular}

Este percentual refere-se a comparação de injetores parcialmente depositados, após a realização do ensaio em dinamômetro de chassis, com um bico injetor novo, utilizado como referência. A diferença percentual apresentada refere-se a diferença de massa de combustível injetada por pulso de injeção.

Pode-se notar que, mesmo com o valor de FRA tendo atingido 1,2995 ao final do teste, a maior média percentual de vazão perdido para os 4 tempos de injeção testados ocorreu no cilindro 4, chegando a aproximadamente 15,7\%.

Os resultados podem ser observados também através do gráfico (Figura 5.22) a seguir, que apresenta a massa injetada por pulso de injeção dos quatro cilindros, comparados a um bico injetor novo, de referência. 


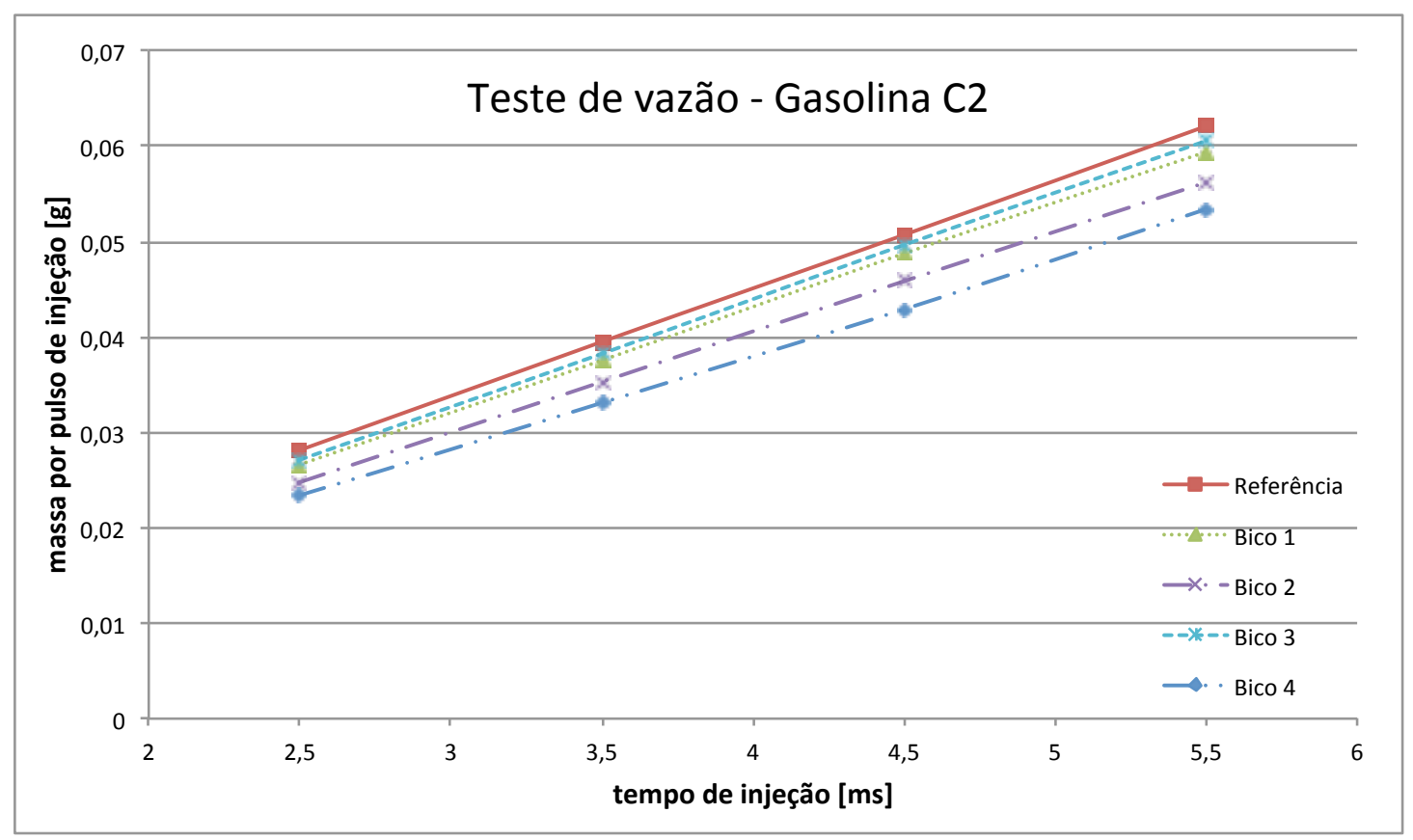

Figura 5.22: Comparação entre os bicos injetores que saíram do teste de dinamômetro com a gasolina $\mathrm{C} 2$ e um bico injetor novo, de referência.

\subsubsection{Dinamômetro de chassis - Peugeot 408 - combustível C3}

O segundo teste realizado nesta etapa utilizou a gasolina $\mathrm{C} 3$, "dopada" com um maior teor de sulfato, porém ainda dentro dos valores permitidos pela norma técnica da ANP N ${ }^{\circ}$, de 2011.

Para este combustível, além do ensaio realizado no dinamômetro de chassis, foi realizada uma caracterização da gasolina e um teste de vazão. Não foi necessária a realização de uma análise dos depósitos encontrados, uma vez que para testes utilizando o mesmo combustível já haviam sido registrados casos contendo um alto teor de enxofre nas camadas depositadas.

A Figura 5.23, a seguir, ilustra o monitoramento constante da variável de adaptação do tempo de injeção ao longo do teste. Como de costume, no início do ensaio, como os bicos injetores são novos, o FRA é 1, pois ainda não há entupimento em nenhum dos bicos injetores. 


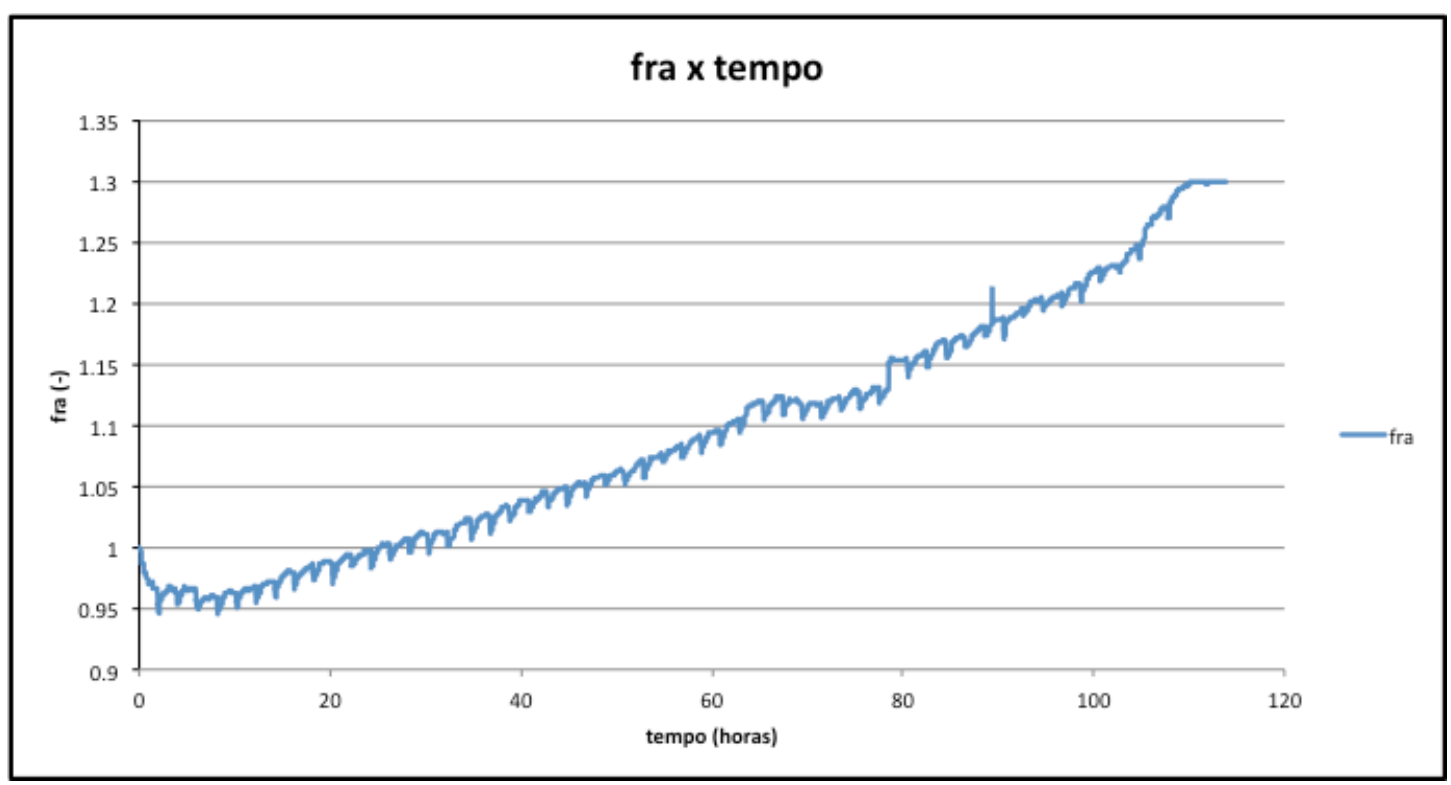

Figura 5.23: Acompanhamento do FRA para o ensaio em dinamômetro utilizando gasolina $\mathrm{C} 3$.

O FRA atingiu seu valor limite com uma distância percorrida equivalente a $4.205 \mathrm{~km}$. A caracterização química do combustível C3 está apresentada na Tabela 5.15.

Tabela 5.15: Caracterização do combustível C3.

\begin{tabular}{|c|c|}
\hline & Gasolina C3 \\
\hline Goma Lavada $(\mathrm{mg} / 100 \mathrm{~mL})$ & 8,3 \\
\hline Enxofre Total & 20 \\
\hline Teor Alcoólico \%V/V & 27 \\
\hline Água $(\mathrm{mg} / \mathrm{kg})$ & 5041 \\
\hline Olefina (\%) & 82,9 \\
\hline Saturado (\%) & 56,1 \\
\hline Aromático (\%) & 14,6 \\
\hline Benzeno (\%) & 0 \\
\hline IAD & 88,7 \\
\hline
\end{tabular}


Tabela 5.16: Resultado da cromatografia de íons positivos.

\begin{tabular}{|c|c|c|c|c|}
\hline Íons Positivos & $\mathrm{Na}^{+}(\mathrm{ppm})$ & $\mathrm{K}^{+}(\mathrm{ppm})$ & $\mathrm{Ca}^{2+}(\mathrm{ppm})$ & $\mathrm{Mg}^{2+}(\mathrm{ppm})$ \\
\hline Gasolina $C 3$ & 14,50 & 0,50 & 0,23 & 0,034 \\
\hline
\end{tabular}

Tabela 5.17: Resultado da cromatografia de íons negativos.

\begin{tabular}{|c|c|c|c|c|c|c|}
\hline Íons Negativos & $\begin{array}{c}\mathrm{F}^{-} \\
(\mathrm{ppm})\end{array}$ & $\begin{array}{c}\mathrm{Cl}^{-} \\
(\mathrm{ppm})\end{array}$ & $\begin{array}{c}\mathrm{Br}^{-} \\
(\mathrm{ppm})\end{array}$ & $\begin{array}{c}\mathrm{NO}_{3^{-}} \\
(\mathrm{ppm})\end{array}$ & $\begin{array}{c}\mathrm{HPO}_{4}^{-2} \\
(\mathrm{ppm})\end{array}$ & $\begin{array}{c}\mathrm{SO}_{4}^{{ }^{-}} \\
(\mathrm{ppm})\end{array}$ \\
\hline Gasolina $C 3$ & $<0,01$ & 2,31 & $<0,10$ & 0,45 & 0,14 & 0,91 \\
\hline
\end{tabular}

Como pode-se notar, através da Figura 5.23, apresentada anteriormente, a distância percorrida no dinamômetro de chassis até alcançar o valor limite do FRA para este combustível foi consideravelmente menor do que a percorrida utilizando a gasolina a $\mathrm{C} 2$. Este fato pode ser explicado pelo maior teor de sulfato dosado na gasolina, conforme mostrado nas análises de íons positivos e negativos apresentadas nas Tabelas 5.16 e 5.17. $\mathrm{O}$ sulfato $\left(\mathrm{SO}_{4}^{2-}\right)$ medido na gasolina $\mathrm{C} 3$ foi de 0,91 ppm, enquanto a gasolina anterior apresentou um valor de 0,79 ppm. Outro fator que pode ter contribuído de certa forma para o rápido entupimento dos bicos injetores foi o teor de goma lavada observado na gasolina $\mathrm{C} 3$ encomendada.

Para quantificar a perda de vazão decorrente da formação de depósitos, foi realizado um teste de vazão nos injetores retirados do veículo. O resultado encontrado está apresentado na Tabela 5.18, a seguir.

Tabela 5.18: Resultado do teste de vazão feito nos bicos injetores após o teste em dinamômetro de chassis com o combustível C3.

\begin{tabular}{|c|c|c|c|c|}
\hline \multicolumn{5}{|c|}{ Percentual de vazão dos injetores utilizados no ensaio com a gasolina C3 (\%) } \\
\hline $\begin{array}{c}\text { Tempo de } \\
\text { injeção }\end{array}$ & Cilindro 1 & Cilindro 2 & Cilindro 3 & Cilindro 4 \\
\hline $2,5 \mathrm{~ms}$ & 68,07 & 70,53 & 67,89 & 81,75 \\
\hline $3,5 \mathrm{~ms}$ & 68,08 & 70,57 & 68,08 & 82,54 \\
\hline $4,5 \mathrm{~ms}$ & 68,38 & 71,01 & 68,48 & 83,46 \\
\hline $5,5 \mathrm{~ms}$ & 68,80 & 71,44 & 69,12 & 85,44 \\
\hline
\end{tabular}

Conforme apresentado na tabela acima, o injetor que teve sua vazão mais comprometida foi o referente ao cilindro de número 3 , chegando a média de 
aproximadamente $31,7 \%$ de perda de massa de combustível injetada por pulso de injeção.

O resultado do teste de vazão realizado para este ensaio está apresentado em forma de gráfico, através da Figura 5.24, comparando os injetores de número 1,2,3 e 4, com um injetor novo.

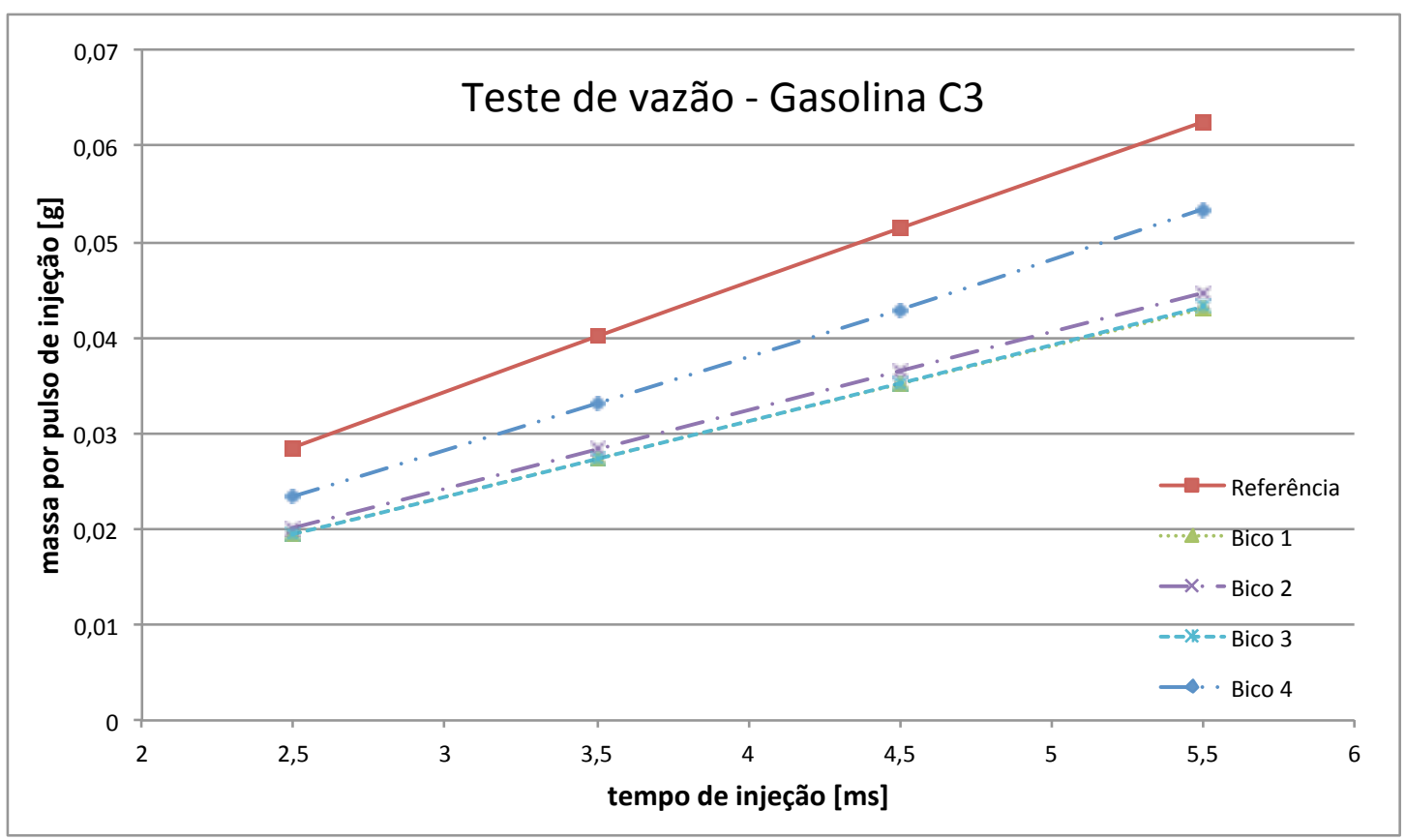

Figura 5.24: Vazão comparativa entre os bicos injetores 1,2,3 e 4, após o ensaio em dinamômetro de chassis com um bico injetor novo.

A numeração dos injetores foi feita considerando o injetor de número 1 o mais próximo ao volante do motor.

Através dos resultados apresentados nos testes de vazão dos ensaios realizados com o veículo Peugeot 408, pode-se notar que a obstrução dos injetores não ocorre da mesma maneira para os quatro cilindros. Isto faz com que o motor trabalhe fora de sua forma otimizada, uma vez que a central envia o mesmo comando de adaptação do tempo de injeção para os quatro cilindros.

Notou-se também, através da comparação dos resultados, que a maior obstrução nem sempre ocorre no mesmo cilindro. Por exemplo, no ensaio realizado com a gasolina $\mathrm{C} 2$ o cilindro 4 teve maior obstrução, enquanto no teste feito com o combustível $\mathrm{C} 3$, o injetor 3 apresentou maior perda na vazão de combustível. 


\subsection{Dinamômetro de chassis - terceira etapa}

A terceira fase de ensaios realizados no dinamômetro de chassis foi feita utilizando um Peugeot $207 \mathrm{hp}$, também equipado com o motor EP6 CDTm, turbocomprimido.

Nesta etapa foi realizado um teste, utilizando o combustível $\mathrm{C} 4$, resumido na Tabela 5.19, a seguir.

Tabela 5.19: Resumo do teste realizado na terceira etapa de ensaios no dinamômetro de chassis.

\begin{tabular}{|c|c|c|c|c|}
\hline TESTE & COMB & DIST. & FRA Final & Observações \\
\hline T13 & C4 & 9.985 & 1,013 & Teste com monitoramento do FRA e teste de vazão \\
\hline
\end{tabular}

\subsubsection{Dinamômetro de chassis - Peugeot 207 - combustível C4}

É possível notar, através do gráfico a seguir (Figura 5.25) que neste ensaio, diferente dos demais apresentados anteriormente, a variável de adaptação do tempo de injeção não atingiu seu valor limite de 1,3. Neste caso, seguindo a metodologia apresentada no Capítulo 4, o teste foi encerrado quando o veículo atingiu aproximadamente $10.000 \mathrm{~km}$ rodados. 


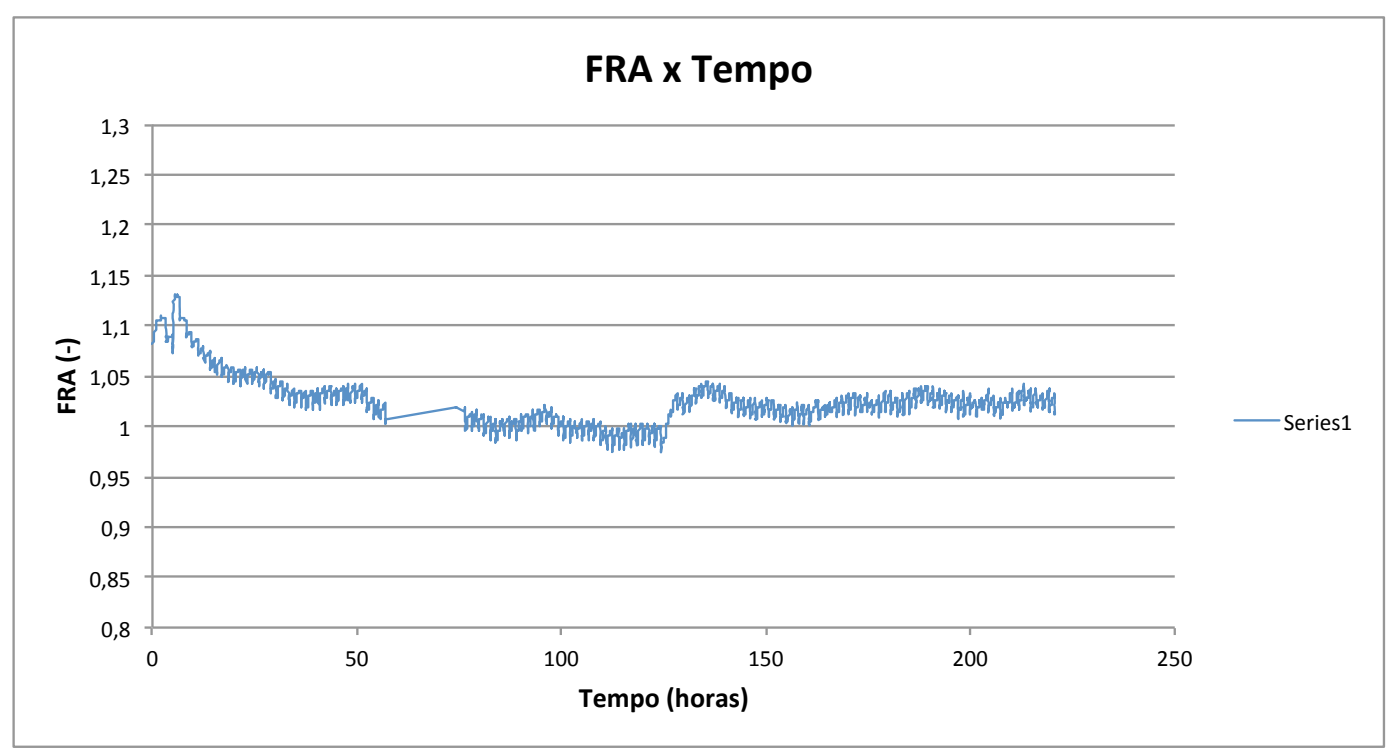

Figura 5.25: Acompanhamento da variável de correção do tempo de injeção ao $\log$ o do ensaio utilizando a gasolina $\mathrm{C} 4$, no dinamômetro de chassis.

O valor do FRA neste ensaio não começou com o seu valor nominal de 1 , devido ao fato das adaptações da central eletrônica não terem sido zeradas após alguma rodagem anterior. Porém, a variável FRA teve seu valor "reaprendido" para aproximadamente 1, após algumas horas de teste. Isto ocorre em função da constante leitura da sonda lambda. Como a correção do tempo de injeção estava um pouco acima do valor real, este sensor "lia" menos oxigênio do que deveria, pois a mistura estava rica, com mais combustível do que deveria. Sendo assim, buscando a mistura estequiométrica, o valor de FRA foi se alterando até que se aproximasse do valor inicial dos outros ensaios, 1.

A gasolina C4 foi encomendada com um teor de sulfato mais baixo do que dos combustíveis testados, para que se desse continuidade ao processo de investigação da influência do sulfato na formação dos depósitos. Portanto, o resultado obtido durante o ensaio pode estar atribuído a este baixo teor de sulfato dosado no combustível.

Não foi possível, dentro do escopo deste trabalho, realizar testes com uma matriz de combustíveis extensa o suficiente para que houvesse o controle isoladamente de cada uma das variáveis de interesse na gasolina. Um exemplo disso é que ao adicionar sulfato a um combustível eleva-se seu teor de enxofre total. O ideal seria que este valor se mantivesse constante para todas as gasolinas testadas variando somente o teor de sulfato dosado. Para tal seria necessário a 
utilização de gasolinas bases com teores de enxofre tão menores quanto maior fosse a adição de sulfato. Porém, não houve disponibilidade de correntes de combustível que permitissem a realização dos ensaios desta maneira.

$\mathrm{O}$ resultado da caracterização da gasolina $\mathrm{C} 4$ está apresentado nas tabelas a seguir:

Tabela 5.20: Caracterização da gasolina C4.

\begin{tabular}{|c|c|}
\hline & Gasolina C4 \\
\hline Goma Lavada $(\mathrm{mg} / 100 \mathrm{~mL})$ & 2,2 \\
\hline Enxofre Total & 12 \\
\hline Teor Alcoólico \%V/V & 25 \\
\hline Água $(\mathrm{mg} / \mathrm{kg})$ & 2280 \\
\hline Olefina (\%) & 0,2 \\
\hline Saturado (\%) & 54 \\
\hline Aromático (\%) & 15,9 \\
\hline Benzeno (\%) & 0 \\
\hline IAD & 89,7 \\
\hline
\end{tabular}

Tabela 5.21: Resultado da análise de cátions da gasolina C4.

\begin{tabular}{|c|c|c|c|c|}
\hline Íons Positivos & $\mathrm{Na}^{+}(\mathrm{ppm})$ & $\mathrm{K}^{+}(\mathrm{ppm})$ & $\mathrm{Ca}^{2+}(\mathrm{ppm})$ & $\mathrm{Mg}^{2+}(\mathrm{ppm})$ \\
\hline Gasolina $C 4$ & 2,20 & 4,32 & 0,58 & 0,086 \\
\hline
\end{tabular}

Tabela 5.22: Resultado da análise de ânions da gasolina C4.

\begin{tabular}{|c|c|c|c|c|c|c|}
\hline Íons Negativos & $\begin{array}{c}\mathrm{F}^{-} \\
(\mathrm{ppm})\end{array}$ & $\begin{array}{c}\mathrm{Cl}^{-} \\
(\mathrm{ppm})\end{array}$ & $\begin{array}{c}\mathrm{Br}^{-} \\
(\mathrm{ppm})\end{array}$ & $\begin{array}{c}\mathrm{NO}_{3}^{-} \\
(\mathrm{ppm})\end{array}$ & $\begin{array}{c}\mathrm{HPO}_{4}^{-2} \\
(\mathrm{ppm})\end{array}$ & $\begin{array}{c}\mathrm{SO}_{4}^{2^{-}} \\
(\mathrm{ppm})\end{array}$ \\
\hline Gasolina $C 4$ & $<0,10$ & 0,11 & $<0,11$ & 0,010 & 0,005 & 0,0098 \\
\hline
\end{tabular}

A Tabela 5.22, acima, apresenta o valor de sulfato, de 0,0098 ppm, presente na gasolina C4. Este valor é muito baixo, quando comparado aos outros combustíveis utilizados. Possivelmente, devido a este fato, não foram observadas alterações significativas na adaptação do tempo de injeção.

Neste ensaio foi realizado também um teste de vazão nos bicos injetores. Desta vez, porém, a metodologia foi modificada. Ao invés de se utilizar um bico injetor novo como referência para comparação, as vazões foram medidas antes e 
depois do ensaio, nos quatro bicos. Desta forma, a comparação foi feita cilindro a cilindro, antes e depois do ensaio no dinamômetro de chassis.

O resultado do ensaio de vazão realizado nos bicos injetores que saíram do teste feito com a gasolina $\mathrm{C} 4$, mostrou que realmente não houve formação de depósitos significativa após os $9.985 \mathrm{~km}$ rodados. Através da Tabela 5.23, apresentada a seguir, pode-se notar que o cilindro que obteve a maior obstrução foi o de número 1, apresentando uma média de aproximadamente $3,3 \%$ de vazão perdida.

Tabela 5.23: Resultado do teste de vazão realizado com os bicos injetores retirados do veículo após o teste com a gasolina $\mathrm{C} 4$.

\begin{tabular}{|c|c|c|c|c|}
\hline \multicolumn{5}{|c|}{ Percentual de vazão dos injetores utilizados no ensaio com a gasolina C4 (\%) } \\
\hline $\begin{array}{c}\text { Tempo de } \\
\text { injeção }\end{array}$ & Cilindro 1 & Cilindro 2 & Cilindro 3 & Cilindro 4 \\
\hline $2,5 \mathrm{~ms}$ & 93,52 & 97,73 & 99,93 & 96,01 \\
\hline $3,5 \mathrm{~ms}$ & 96,34 & 95,88 & 98,92 & 96,26 \\
\hline $4,5 \mathrm{~ms}$ & 97,01 & 98,42 & 100,00 & 99,37 \\
\hline $5,5 \mathrm{~ms}$ & 98,28 & 99,60 & 99,88 & 99,20 \\
\hline
\end{tabular}

Os resultados gráficos apresentados nas Figuras 5.26 a 5.29, abaixo, apresentam a comparação de antes e depois do teste para cada cilindro. 


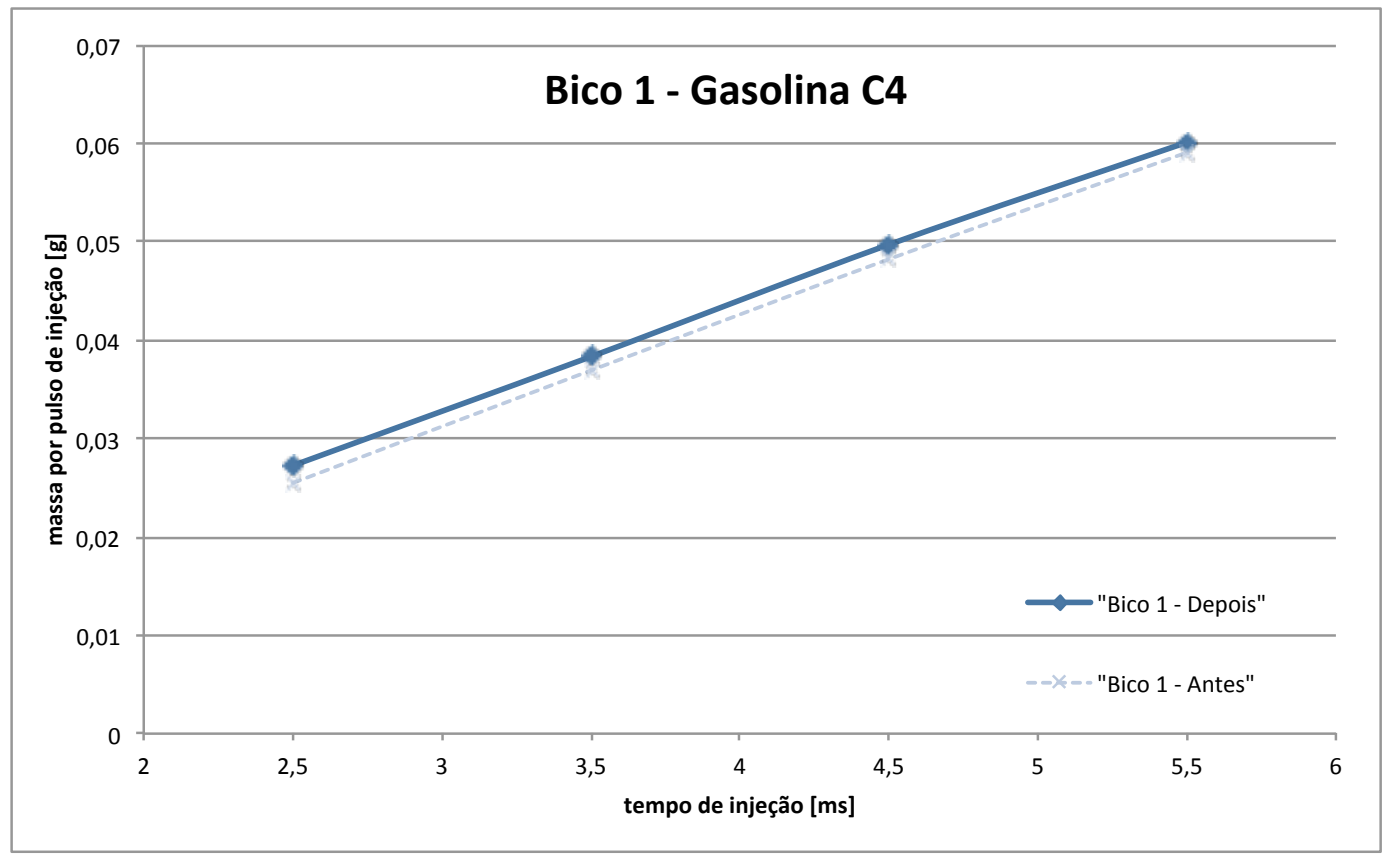

Figura 5.26: Resultado do teste de vazão feito no bico injetor referente ao cilindro 1 , antes e depois do ensaio.

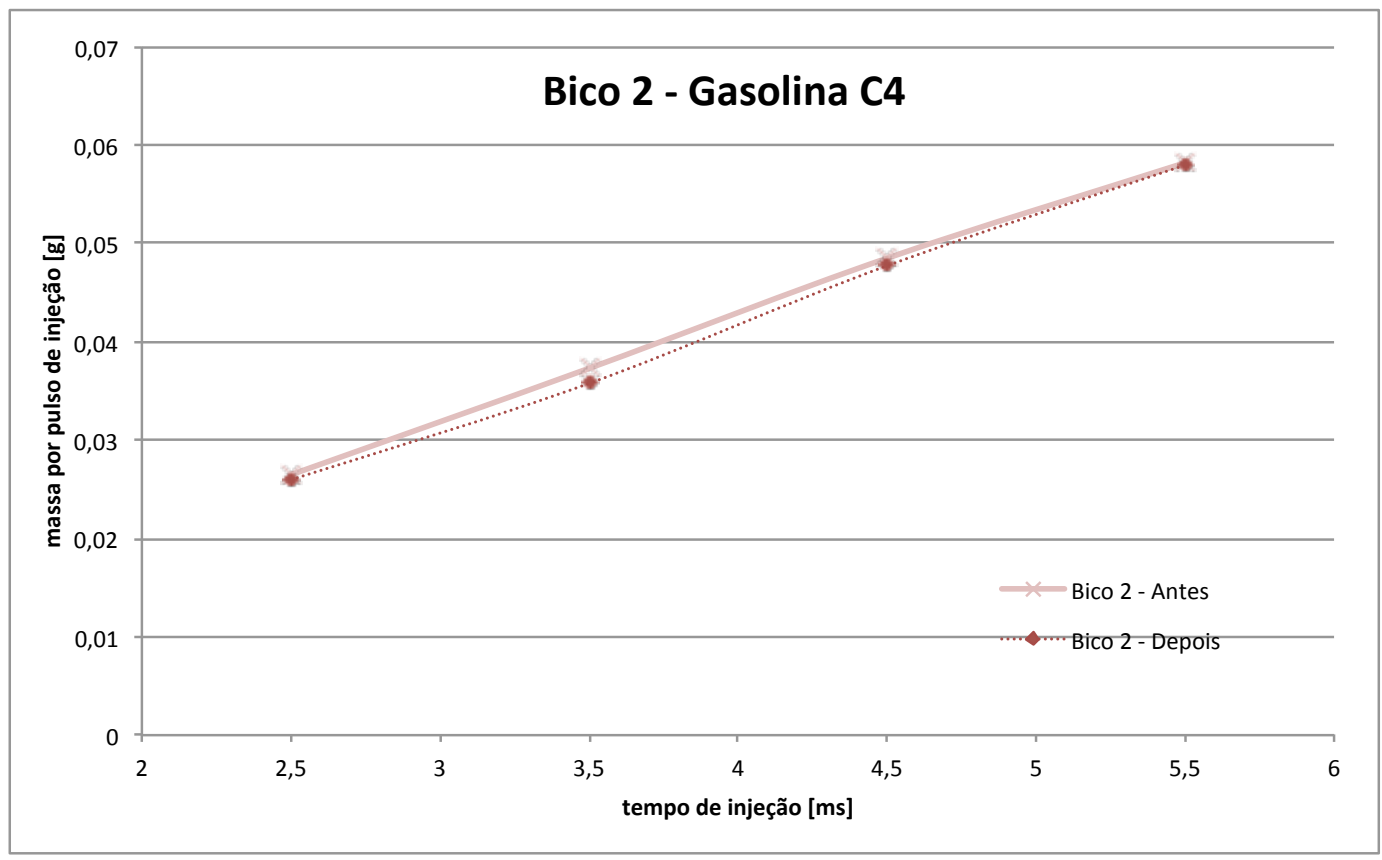

Figura 5.27: Resultado do teste de vazão feito no bico injetor referente ao cilindro 2, antes e depois do ensaio. 


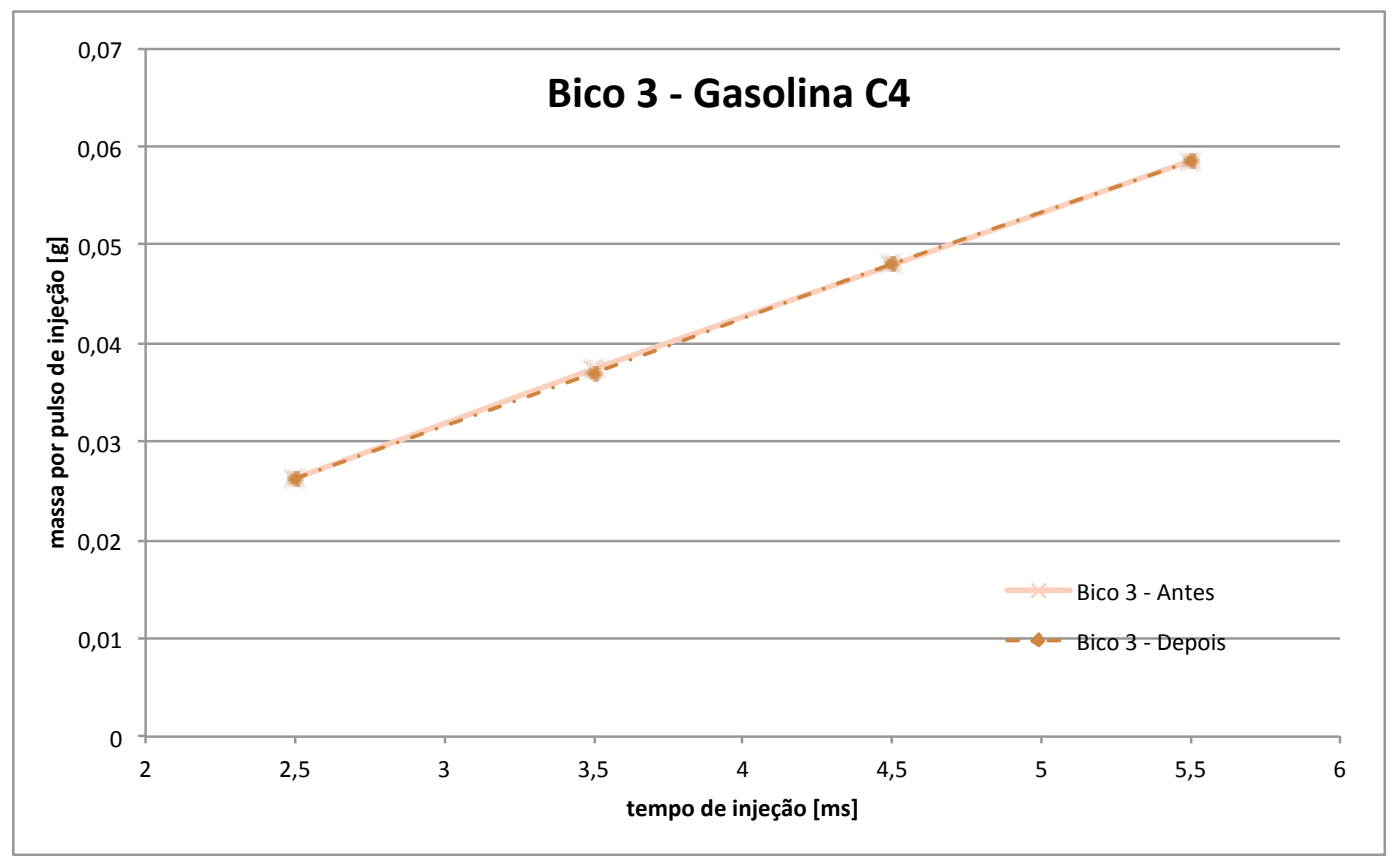

Figura 5.28: Resultado do teste de vazão feito no bico injetor referente ao cilindro 3 , antes e depois do ensaio.

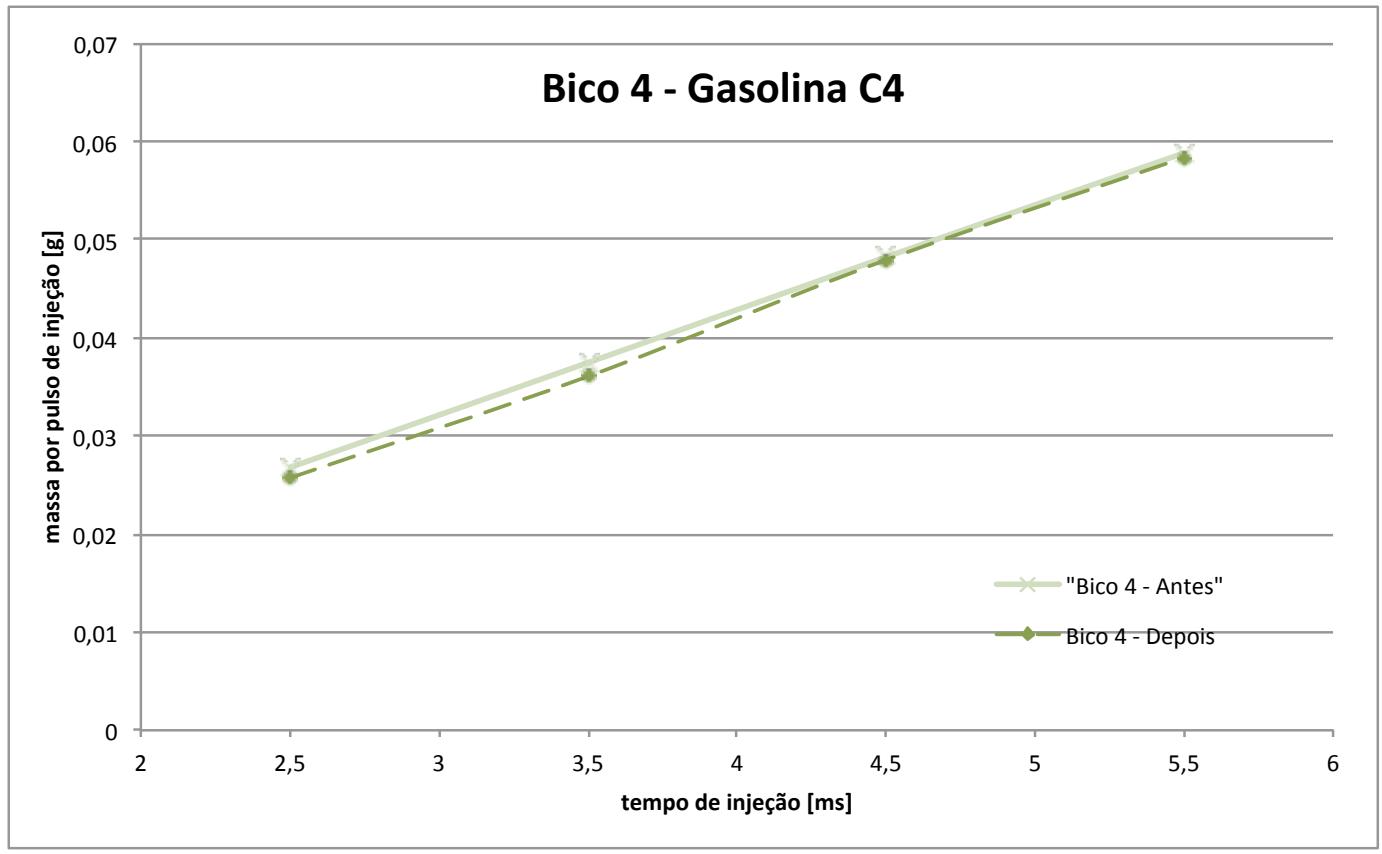

Figura 5.29: Resultado do teste de vazão feito no bico injetor referente ao cilindro 4, antes e depois do ensaio. 
Os gráficos, apresentados nas Figuras 5.26 a 5.29, reforçam a teoria de que o ensaio realizado com o combustível $\mathrm{C} 4$, dosado com um baixo teor de sulfato $(0,0098$ ppm) não reduziu significativamente a vazão de combustível através dos injetores. Portanto, mesmo tendo rodado aproximadamente $10.000 \mathrm{~km}$, o veículo não teve seus injetores depositados.

\subsection{Road Test}

Com os resultados obtidos nos ensaios realizados em dinamômetro de chassis e, principalmente, na análise química dos depósitos formados, surge a necessidade de verificar a eficácia dos aditivos encontrados no mercado nacional para limpeza de injetores.

Os testes foram conduzidos de acordo com a metodologia descrita no item 4.2, utilizando um veículo de referência (sem aditivos), e quatro outros veículos que utilizavam o aditivo a ser testado segundo os métodos keep clean e clean up.

É importante salientar que o método de aplicação dos aditivos no tanque de combustível foi discutido diretamente com o fabricante dos mesmos. Desta forma, pôde-se garantir que os aditivos trabalhariam da maneira correta, visando a remoção dos depósitos formados. Por questões éticas, o nome do fabricante dos aditivos não será divulgado ao longo do trabalho.

A seguir serão analisados os resultados obtidos nas rodagens dos veículos utilizando aditivo.

\subsubsection{Aditivo 1}

O primeiro aditivo testado foi utilizado em uma rodagem com a gasolina C1. O gráfico a seguir (Figura 5.30) mostra a evolução do FRA ao longo do ensaio.

Pode-se observar, a partir da Figura 5.30, que os cinco veículos utilizados no teste atingiram o valor máximo de adaptação do tempo de injeção, o que leva a concluir que houve formação de depósitos em todos os veículos testados com o aditivo 1, inclusive o veículo de referência (V5). 


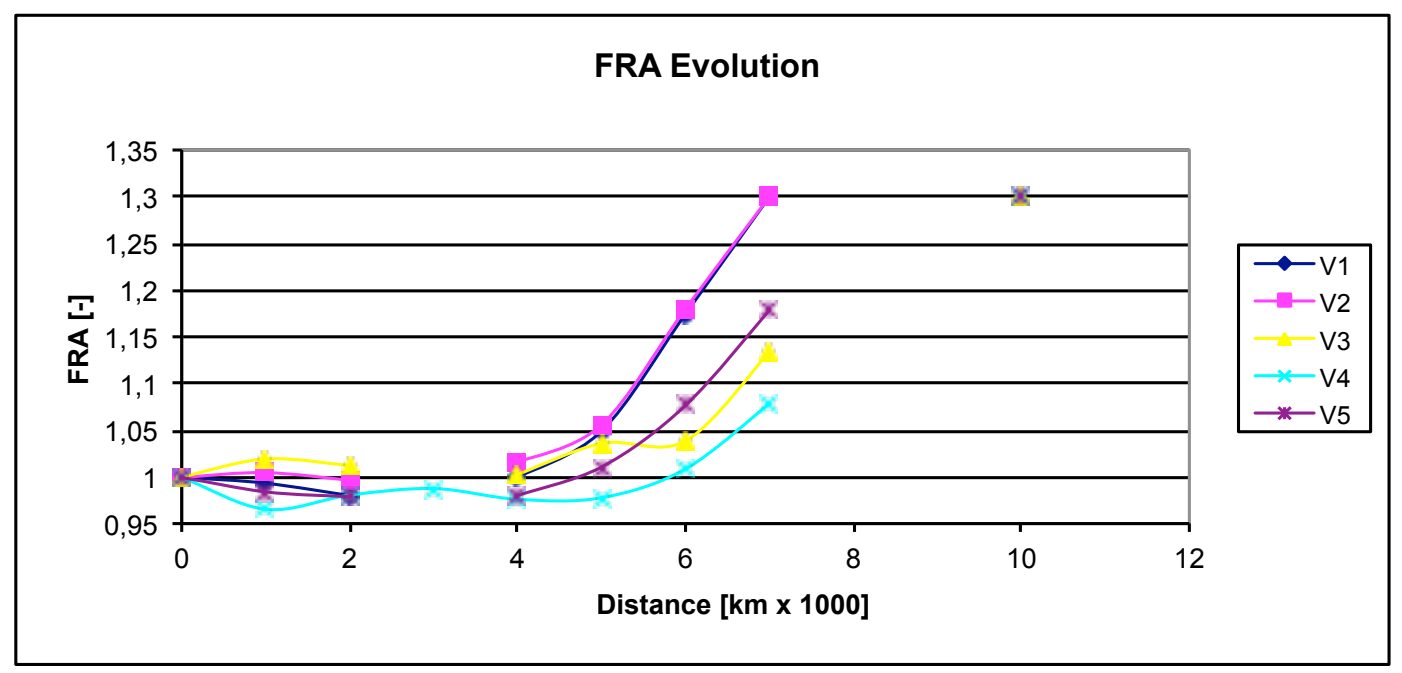

Figura 5.30: Acompanhamento da variável FRA, para o grupo de veículos, ao longo dos ensaios feitos com o primeiro aditivo.

De acordo com a metodologia utilizada no Road Test, as aquisições eram feitas a cada 1.000 quilômetros. No ensaio apresentado acima, as aquisições que seriam com 7, 8 e 9 mil quilômetros rodados não foram executadas. Porém, a aquisição voltou a ser feita na marca dos $10.000 \mathrm{~km}$ rodados.

Diferentemente do que se esperava, os veículos que utilizaram o método de aplicação do aditivo Keep Clean (V1 e V2) onde, teoricamente, os depósitos surgiriam de maneira mais gradativa, foram os veículos que tiveram o crescimento mais rápido da variável FRA. O método Clean Up (V3 e V4) de aplicação de aditivo, adicionando uma maior quantidade de aditivo com $5.000 \mathrm{~km}$ de teste também não se mostrou efetivo com o aditivo 1. Pode-se notar isso através da verificação das aquisições em $6.000 \mathrm{~km}$, onde a variável FRA permanece subindo.

No ponto relativo a $10.000 \mathrm{~km}$ rodados, todos os veículos em teste já haviam atingido o valor limite de 1,3 para a adaptação do tempo de injeção.

Portanto, pode-se concluir que o aditivo 1 de nada influenciou a formação de depósitos, sendo considerado como não-efetivo.

\subsubsection{Aditivo 2}


Os ensaios conduzidos com o aditivo 2 também foram realizados utilizando a gasolina $\mathrm{C} 1$. Os veículos que utilizaram o método Keep Clean de adição de aditivo ao tanque estão apresentados no gráfico a seguir como sendo V6 e V7. Já os veículos que rodaram utilizando o método Clean $U p$ estão demonstrados a seguir como V8 e V9. Portanto, o veículo de referência é o de número 10 (V10).

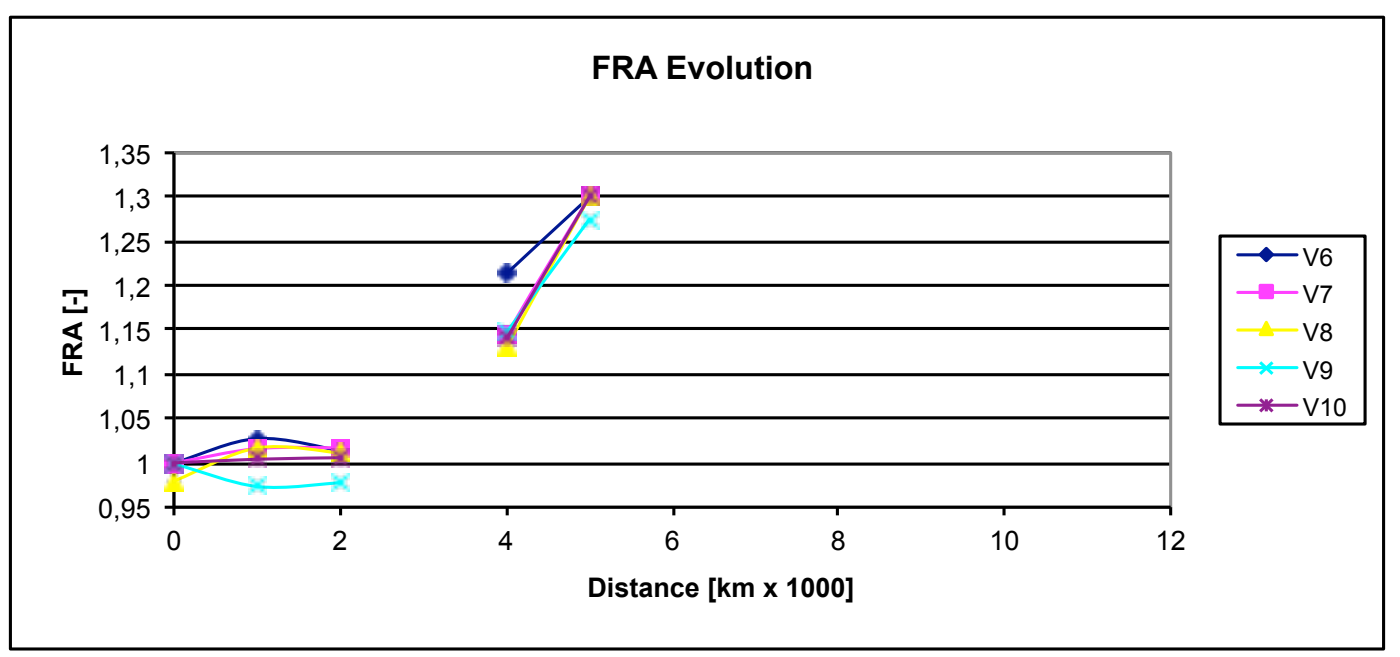

Figura 5.31: Acompanhamento da variável FRA ao longo dos ensaios feitos com o segundo aditivo.

Neste ensaio, todos os veículos apresentaram resultados muito próximos nos $2.000 \mathrm{~km}$ iniciais. O veículo de número 9, apresentou uma queda no valor relativo a variável FRA do instante inicial até os mil primeiros quilômetros rodados. Esta queda é natural da adaptação do tempo de injeção, que pode variar até $\pm 0,02$ de veículo para veículo, quando não há formação de depósitos ou nenhuma mudança significativa no sistema de admissão do veículo.

Por um problema de logística, não houve aquisição do ponto relativo a $3.000 \mathrm{~km}$. Porém, quando o veículo atingiu 4.000 rodados, pode-se notar que quatro dos cinco veículos já apresentavam o valor de FRA próximo a 1,15, enquanto o veículo de número 6 já passava da marca de 1,20.

Por fim, com $5.000 \mathrm{~km}$ rodados, todos os veículos que estavam sendo testados com o aditivo de número 2 já haviam atingido o valor máximo de, aproximadamente, 1,3 para o FRA. Os veículos V8 e V9 (clean up) atingiram a marca de quilometragem estipulada na metodologia para a aplicação de aditivo já 
com o valor máximo de FRA. Sendo assim, não houve aplicação de aditivo nestes veículos para este ensaio.

É possível afirmar, portanto, que o aditivo 2 também não se mostrou efetivo na remoção ou prevenção dos depósitos formados com as gasolinas testadas ao longo deste trabalho.

\subsubsection{Aditivo 3}

Os ensaios com o aditivo 3 não contaram com um veículo de referência. Porém, a gasolina utilizada foi a mesma dos testes com o aditivo 1 e 2 , o que permite que uma comparação seja feita com os veículos referência relativos a estes testes.

Os veículos V11 e V12 realizaram o teste utilizando o método Keep Clean de adição do aditivo no tanque, enquanto os veículos V13 e V14 utilizando o modo Clean Up.

Nota-se, pelo gráfico a seguir, que os veículos V11, V12 e V14 começaram o ensaio com valor de FRA igual a 1, e depois este valor sofreu uma pequena queda. Em seguida, com aproximadamente $4.000 \mathrm{~km}$ rodados, os valores de FRA para os veículos V11, V12 e V14 ainda se encontram baixos, entre 1 e 1,1, enquanto o veículo V13 apresentava um valor próximo a 1,2. Na aquisição seguinte, referente aos $5.000 \mathrm{~km}$, notou-se que todos os veículos, com exceção do V14, haviam apresentado um aumento significante do valor do FRA, chegando até seu valor limite de 1,3. 


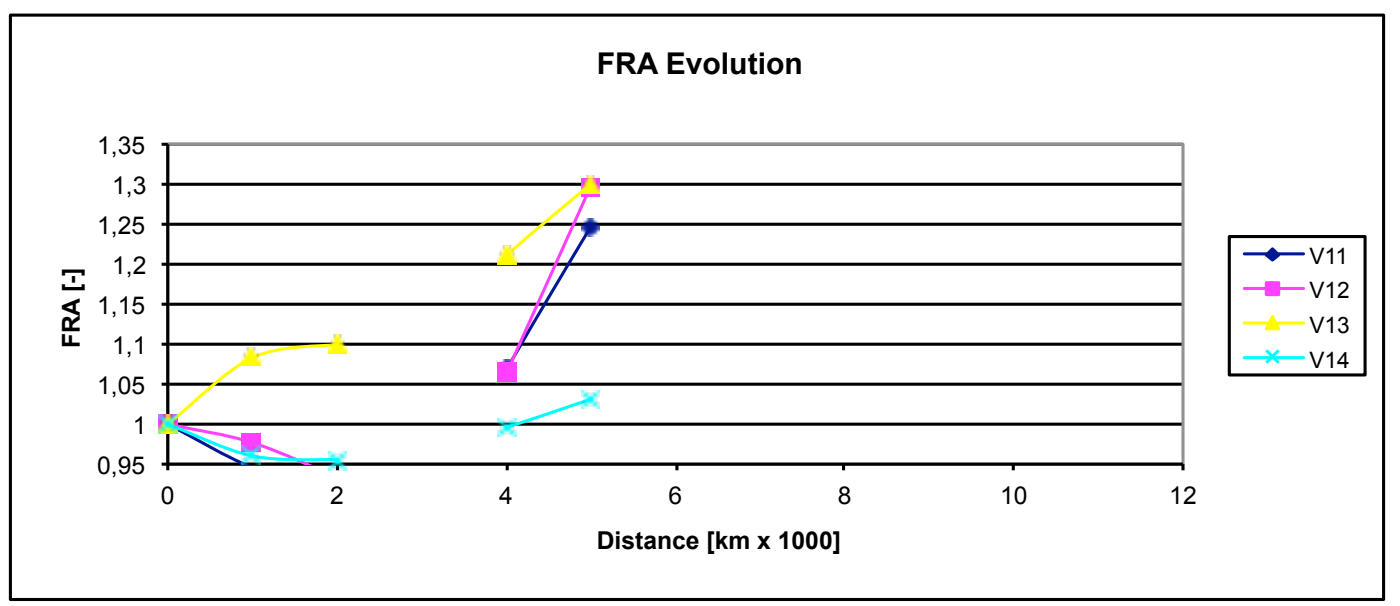

Figura 5.32: Acompanhamento da variável FRA ao longo dos ensaios feitos com o terceiro aditivo.

Com isso, optou-se por parar a rodagem deste grupo de veículos, uma vez que três dos quatro veículos que faziam uso do aditivo 3 já mostravam depósitos significativos, com 5.000 quilômetros. Os veículos que rodavam utilizando o método clean up novamente não tiveram aditivo aplicado no tanque devido a baixa quilometragem final do ensaio.

Portanto, pode-se afirmar, que assim como nos casos dos aditivos 1 e 2, o aditivo 3 também não se mostrou eficiente quanto aos depósitos formados a partir do uso das gasolinas formuladas para o presente trabalho. 


\section{6 \\ Conclusões e Recomendações}

De acordo com os resultados apresentados ao longo do trabalho foi possível chegar as seguintes principais conclusões.

O Road Test preliminar indicou que o primeiro combustível formulado levava a unidade de controle eletrônica do veículo a variar rapidamente a adaptação do tempo de injeção, o que sugeria a formação de depósitos.

Posteriormente, foi realizada uma tentativa de deposição no bico injetor, através da imposição de altas temperaturas em suas paredes, na bancada de vazão. Para isso um ciclo de $10.000 \mathrm{~km}$, à velocidade constante, foi simulado. Não foram verificadas alterações significativas na vazão mássica de combustível por pulso, ao longo deste ensaio. Este resultado indica que as condições de operação do motor, tais como combustão, pressão e temperatura na câmara, são de importância fundamental na formação de depósitos no interior e na superfície externa do bico injetor.

A caracterização dos depósitos formados no interior e na superfície externa dos bicos injetores durante os testes no dinamômetro de chassis e Road Tests, utilizando as gasolinas $C 1$ e $C 2$, indicaram a presença de compostos ricos em enxofre.

Notou-se também, através dos testes realizados no dinamômetro de chassis, que a distância percorrida estava ligada diretamente ao teor de sulfato presente no combustível. Os veículos que utilizaram as gasolinas encomendadas com um maior teor de sulfato percorreram uma menor distância até atingir o valor limite para a adaptação do tempo de injeção. Este resultado leva a crer que o teor de sulfato dosado na gasolina é inversamente associado à distância em que o veículo percorre até atingir o valor máximo de $F R A$.

Os testes de vazão realizados nos injetores utilizados nos testes em dinamômetro reforçaram a tendência de que o percentual de entupimento dos 
bicos também tem relação com o teor de sulfato do combustível. Isso foi observado nos ensaios realizados com os injetores utilizados no veículo Peugeot 408 , após os testes com as gasolinas $C 2$ e $C 3$, e também no ensaio realizado com o Peugeot $207 \mathrm{hp}$.

Os maiores níveis de depósitos observados podem ter sido influenciados também pelos teores mais elevados de goma lavada em alguns dos combustíveis encomendados. Este fato pode estar relacionado com o tempo e condições de estocagem do combustível entre os testes realizados.

Um resumo destes resultados pode ser observado graficamente através da Figura 6.1, apresentada abaixo.

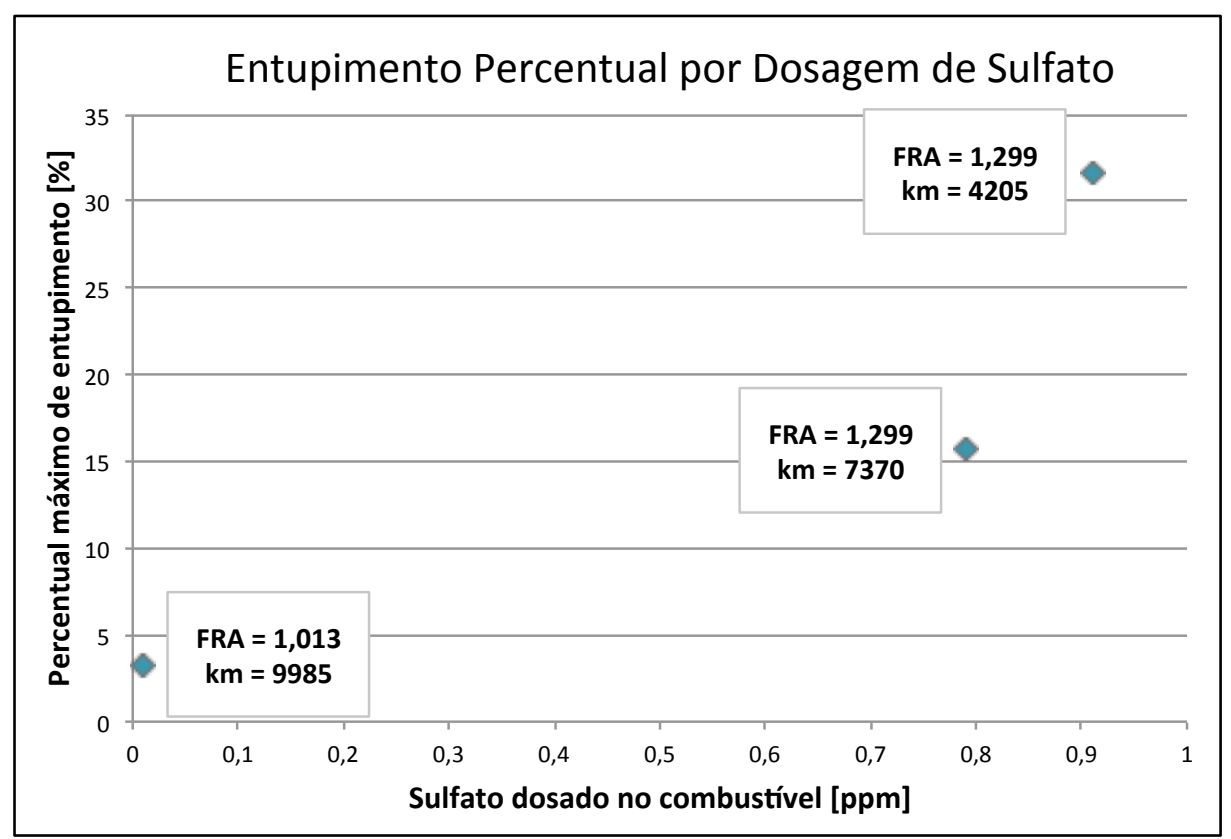

Figura 6.1: Resumo gráfico dos principais resultados obtidos nos testes de dinamômetro de chassis e ensaios de vazão nos bicos injetores.

Ainda através dos testes de vazão, foi possível verificar que, conforme visto na revisão bibliográfica, os depósitos se formam em diferentes níveis para os quatro cilindros. A central eletrônica, por sua vez, envia o mesmo comando de correção do tempo de injeção para todos os cilindros. Isto pode levar o motor a funcionar de maneira não otimizada e fora da estequiometria em alguns dos cilindros, à medida que os depósitos vão se formando. 
Os Road Tests realizados demonstraram que nenhum dos aditivos utilizados durante os ensaios foi eficaz na limpeza ou prevenção dos depósitos formados. Este fato pode ser explicado através da análise química dos depósitos. Os aditivos encontrados no mercado, atualmente, foram desenvolvidos para depósitos ricos em carbonos, sendo fabricados, muitas vezes, para veículos que utilizavam carburador. Estes aditivos são eficazes também na limpeza de bicos injetores de motores com injeção no pórtico de admissão (PFI), que apresentavam a mesma forma de depósitos orgânicos devido à carbonização. Porém, a deposição encontrada nos testes realizados para esta dissertação é de origem inorgânica. Devido a este fato, os aditivos não surtiram efeito.

Sugere-se que, em trabalhos futuros, a investigação seja conduzida também em dinamômetros de bancada de motores. Desta maneira, diferentes ciclos podem ser programados a fim de que se investigue a influência de outros parâmetros na formação de depósitos em motores com injeção direta de gasolina (GDI), como por exemplo, a pressão média efetiva. Nos testes em dinamômetro de motores existe, também, uma maior facilidade no monitoramento de mais variáveis. Outro fator importante recomendando é utilizar a mesma gasolina base nos ensaios, variando somente o teor de sulfato presente no combustível. Isto permitiria uma investigação mais profunda quanto a relação do sulfato com a formação de depósitos.

Por fim, recomenda-se que, com base na correlação de resultados obtidos em dinamômetro de chassis e bancada de motores, uma norma para ciclos de deposição seja desenvolvida para motores de ignição por centelha com tecnologia de injeção direta. 


\section{Referências bibliográficas}

[1] F ZHAO, M., C LAI, D.L HARRINGTON. Automotive spark-ignited direct-injection gasoline engines. Progress in Energy and Combustion Science, Volume 25, Issue 5, October 1999.

[2] JACKSON, NS., STOKES, J., LAKE, TH. e WHITAKER, PA. Research and development of advanced direct injection gasoline engines. Proceedings of the $18^{\text {th }}$ Vienna Motor Symposium, 24-25 April 1997.

[3] CARACCIOLO, F. e STEBAR, RF. An engine dynamometer test for evaluating port fuel injector plugging. SAE Techincal Paper No. $872123,1989$.

[4] HARRIGNTON, DL., STEBAR, RF. e CARACCIOLO, F. Deposit-induced fuel flow reduction in multiport fuel injectors. SAE Techincal Paper No. 892123, 1989.

[5] KINOSHITA, M. ET AL. Study of nozzle deposit formation mechanism for direct injection gasoline engines. Proceedings of JSAE Fall Convention (in Japanese), No. 976, 1997.p.21-4.

[6] MAO, CP. Investigation of carbono formation inside fuel injector systems. Proceedings of ILASS-America'98,1998. p.344-8.

[7] NORMA ANP N7, DE 9.2.2011 - DOU - 10.2.2011 - RETIFICADA DOU 14.4.2011

[8] AVL SOUTH AMERICA. Manual de Operação do Dinamômetro de Chassis AVL - Zolnlner 48”. [S.I.], 2003. Disponível em: $<$ http://nuke.actransaxles.com/TX2Series/tabid/55/language/enUS/Def ault.aspx $>$. 
[9] ABNT NBR 14008:2007. Veículos rodoviários automotores leves Determinação do fator de deterioração das emissões de gases durante o acúmulo de rodagem.

[10] ASTM D7328. Standard Test Method for Determination of Total and Potencial Inorganic Sulfate and Total Inorganic Chloride in Fuel Ethanol by Ion Chromatography Using Aqueous Sample Injection. 